Prepared in cooperation with Public Utility District No. 1 of Kitsap County

\title{
Numerical Simulation of the Groundwater-Flow System of the Kitsap Peninsula, West-Central Washington
}

Scientific Investigations Report 2016-5052

Version 1.1, October 2016 



\section{Numerical Simulation of the Groundwater-Flow System of the Kitsap Peninsula, West-Central Washington}

By Lonna M. Frans and Theresa D. Olsen

Prepared in cooperation with Public Utility District No. 1 of Kitsap County

Scientific Investigations Report 2016-5052

Version 1.1, October 2016 


\title{
U.S. Department of the Interior SALLY JEWELL, Secretary
}

\section{U.S. Geological Survey Suzette M. Kimball, Director}

\author{
U.S. Geological Survey, Reston, Virginia \\ First release: 2016 \\ Revised: October 2016 (ver. 1.1)
}

For more information on the USGS —-the Federal source for science about the Earth, its natural and living resources, natural hazards, and the environment-visit http://www.usgs.gov or call 1-888-ASK-USGS.

For an overview of USGS information products, including maps, imagery, and publications, visit http://store.usgs.gov.

Any use of trade, firm, or product names is for descriptive purposes only and does not imply endorsement by the U.S. Government.

Although this information product, for the most part, is in the public domain, it also may contain copyrighted materials as noted in the text. Permission to reproduce copyrighted items must be secured from the copyright owner.

Suggested citation:

Frans, L.M. and Olsen, T.D., 2016, Numerical simulation of the groundwater-flow system of the Kitsap Peninsula, west-central Washington (ver. 1.1, October 2016): U.S. Geological Survey Scientific Investigations Report 2016-5052, 63 p., http://dx.doi.org/10.3133/sir20165052.

ISSN 2328-0328 (online) 


\section{Contents}

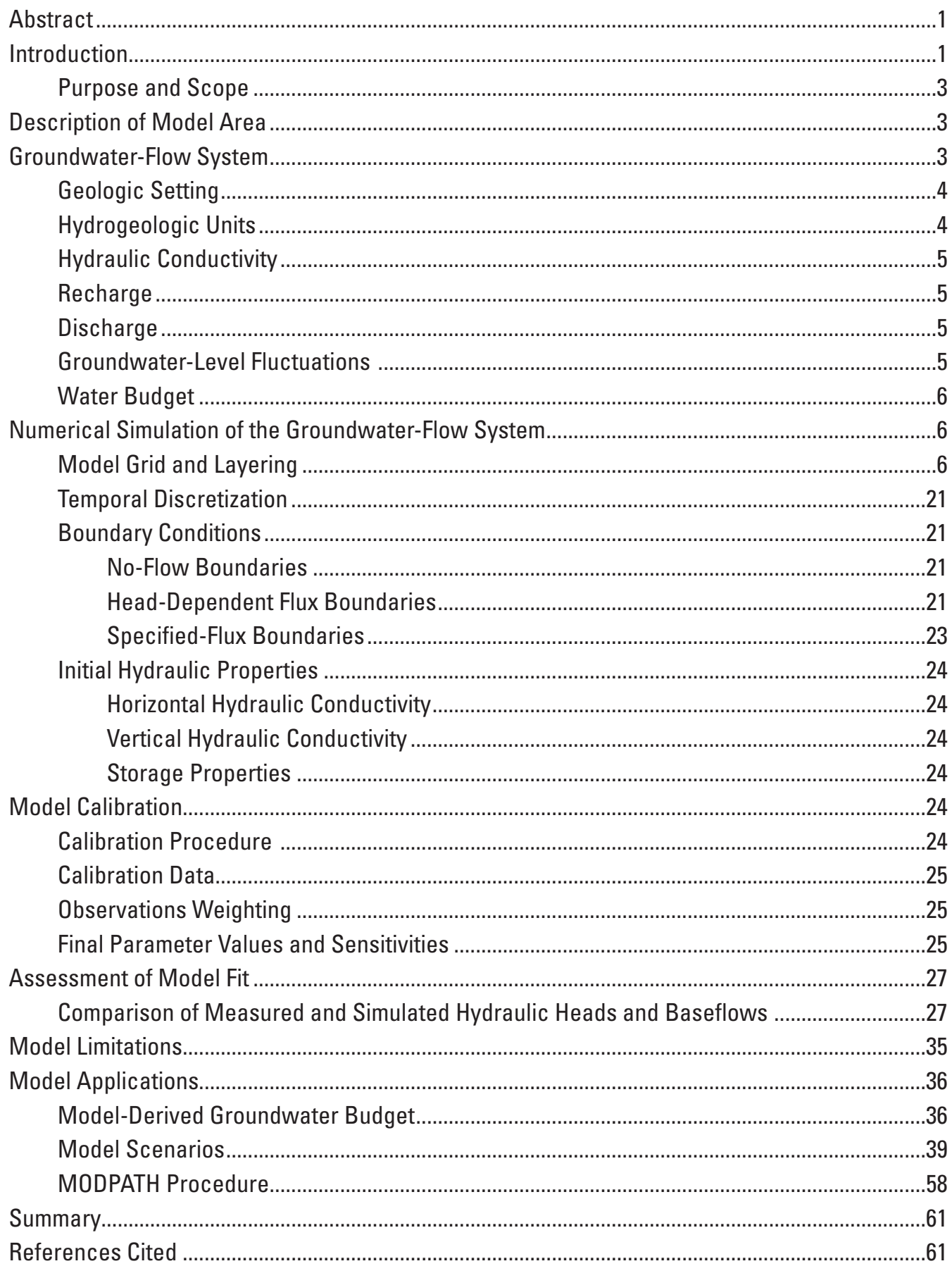




\section{Figures}

1. Map showing location of the Kitsap Peninsula study area, west-central Washington.

2. Map showing location and extent of the groundwater model grid, west-central Washington.

3. Maps showing areal extent of model layers, Kitsap Peninsula, west-central Washington

4. Map showing locations of model streamflow-routing, drain, and general head boundary condition cells, Kitsap Peninsula, west-central Washington

5. Graph showing simulated and measured water-level altitudes in the groundwater-flow model of the Kitsap Peninsula, west-central Washington

6. Maps showing simulated water-level altitudes and location and simulated average magnitude of hydraulic-head residuals, Kitsap Peninsula, west-central Washington.

7. Graphs showing simulated and measured groundwater-level altitudes for selected wells, Kitsap Peninsula, west-central Washington.

8. Graph showing simulated and measured water-level baseflows in the groundwater-flow model of the Kitsap Peninsula, west-central Washington

9. Graph showing simulated annual water budgets, Kitsap Peninsula, west-central Washington, 2005-12.

10. Diagram showing simulated water budgets for individual aquifers, Kitsap Peninsula, west-central Washington, 2012

11. Maps showing simulated water-level altitude changes between the current conditions simulation and steady-state simulation, west-central Washington

12. Maps showing simulated water-level altitude changes between the current conditions simulation and no-pumping simulation, west-central Washington

13. Graph showing change in baseflow between the current conditions simulation and the no pumping simulation, west-central Washington.

14. Maps showing simulated water-level altitude changes between the current conditions simulation and increased pumpage simulation, west-central Washington

15. Graph showing change in baseflow between the current conditions simulation and the increased pumping simulation, west-central Washington ...

16. Maps showing simulated water-level altitude changes between the current conditions simulation and conservation pumpage simulation for the Qva aquifer, west-central Washington.

17. Graph showing change in baseflow between the current conditions simulation and the conservation simulation, west-central Washington....

18. Maps showing simulated water-level altitude changes between the current conditions simulation and decreased recharge simulation, west-central Washington

19. Graph showing change in baseflow between the current conditions simulation and the recharge decrease simulation, west-central Washington..

20. Map showing simulated particle histories for particles that terminated at the water table for selected water-supply wells in the Kitsap Peninsula, west-central Washington.

21. Map showing simulated time of travel for particles released from an individual water-supply well, west-central Washington. 


\section{Tables}

1. Summary of horizontal hydraulic conductivities estimated from specific-capacity data and aquifer tests, by hydrogeologic unit, Kitsap Peninsula, west-central Washington

2. Estimated annual water budget for the groundwater system of the Kitsap

Peninsula, west-central Washington, 2012.

3. Parameter sensitivities and final values for calibration parameters, Kitsap

Peninsula, west-central Washington

4. Calibration statistics for numerical flow model of the Kitsap Peninsula, west-central Washington

5. Water budget for 2005-12 conditions, Kitsap Peninsula, west-central

Washington.

\section{Conversion Factors}

Inch/Pound to International System of Units

\begin{tabular}{|c|c|c|}
\hline Multiply & By & To obtain \\
\hline \multicolumn{3}{|c|}{ Length } \\
\hline inch (in.) & 2.54 & centimeter $(\mathrm{cm})$ \\
\hline inch (in.) & 25.4 & millimeter (mm) \\
\hline foot (ft) & 0.3048 & meter (m) \\
\hline mile (mi) & 1.609 & kilometer $(\mathrm{km})$ \\
\hline \multicolumn{3}{|c|}{ Area } \\
\hline acre & 4,047 & square meter $\left(\mathrm{m}^{2}\right)$ \\
\hline acre & 0.4047 & hectare (ha) \\
\hline acre & 0.4047 & square hectometer $\left(\mathrm{hm}^{2}\right)$ \\
\hline acre & 0.004047 & square kilometer $\left(\mathrm{km}^{2}\right)$ \\
\hline \multicolumn{3}{|c|}{ Volume } \\
\hline acre-foot (acre-ft) & 1,233 & cubic meter $\left(\mathrm{m}^{3}\right)$ \\
\hline acre-foot (acre-ft) & 0.001233 & cubic hectometer $\left(\mathrm{hm}^{3}\right)$ \\
\hline \multicolumn{3}{|c|}{ Flow rate } \\
\hline acre-foot per year (acre-ft/yr) & 1,233 & cubic meter per year $\left(\mathrm{m}^{3} / \mathrm{yr}\right)$ \\
\hline acre-foot per year (acre-ft/yr) & 0.001233 & cubic hectometer per year $\left(\mathrm{hm}^{3} / \mathrm{yr}\right)$ \\
\hline foot per day (ft/d) & 0.3048 & meter per day (m/d) \\
\hline cubic foot per second $\left(\mathrm{ft}^{3} / \mathrm{s}\right)$ & 0.02832 & cubic meter per second $\left(\mathrm{m}^{3} / \mathrm{s}\right)$ \\
\hline cubic foot per day (ft/d) & 0.02832 & cubic meter per day $\left(\mathrm{m}^{3} / \mathrm{d}\right)$ \\
\hline gallon per day (gal/d) & 0.003785 & cubic meter per day $\left(\mathrm{m}^{3} / \mathrm{d}\right)$ \\
\hline \multicolumn{3}{|c|}{ Specific capacity } \\
\hline $\begin{array}{l}\text { gallon per minute per foot } \\
[(\mathrm{gal} / \mathrm{min}) / \mathrm{ft})]\end{array}$ & 0.2070 & liter per second per meter $[(\mathrm{L} / \mathrm{s}) / \mathrm{m}]$ \\
\hline \multicolumn{3}{|c|}{ Hydraulic conductivity } \\
\hline foot per day (ft/d) & 0.3048 & meter per day (m/d) \\
\hline \multicolumn{3}{|c|}{ Hydraulic gradient } \\
\hline foot per mile (ft/mi) & 0.1894 & meter per kilometer $(\mathrm{m} / \mathrm{km})$ \\
\hline \multicolumn{3}{|c|}{ Transmissivity* } \\
\hline foot squared per day $\left(\mathrm{ft}^{2} / \mathrm{d}\right)$ & 0.09290 & meter squared per day $\left(\mathrm{m}^{2} / \mathrm{d}\right)$ \\
\hline
\end{tabular}




\section{Conversion Factors-Continued}

Temperature in degrees Celsius $\left({ }^{\circ} \mathrm{C}\right)$ may be converted to degrees Fahrenheit $\left({ }^{\circ} \mathrm{F}\right)$ as

$$
{ }^{\circ} \mathrm{F}=\left(1.8 \times{ }^{\circ} \mathrm{C}\right)+32 .
$$

Temperature in degrees Fahrenheit $\left({ }^{\circ} \mathrm{F}\right)$ may be converted to degrees Celsius $\left({ }^{\circ} \mathrm{C}\right)$ as

$$
{ }^{\circ} \mathrm{C}=\left({ }^{\circ} \mathrm{F}-32\right) / 1.8 \text {. }
$$

\section{Datums}

Vertical coordinate information is referenced to the North American Vertical Datum of 1988 (NAVD 88).

Horizontal coordinate information is referenced to the North American Datum of 1983 (NAD 83).

Altitude, as used in this report, refers to distance above the vertical datum.

\section{Abbreviations}

KPUD Public Utility District No. 1 of Kitsap County

RMSE root mean-square error

USGS U.S. Geological Survey

\section{Supplemental Information}

Transmissivity: The standard unit for transmissivity is cubic foot per day per square foot times foot of aquifer thickness [(ft $\left.\left.\mathrm{ft}^{3} \mathrm{~d}\right) / \mathrm{ft}^{2}\right] \mathrm{ft}$. In this report, the mathematically reduced form, foot squared per day $\left(\mathrm{ft}^{2} / \mathrm{d}\right)$, is used for convenience. 


\title{
Numerical Simulation of the Groundwater-Flow System of the Kitsap Peninsula, West-Central Washington
}

\author{
By Lonna M. Frans and Theresa D. Olsen
}

\section{Abstract}

A groundwater-flow model was developed to improve understanding of water resources on the Kitsap Peninsula. The Kitsap Peninsula is in the Puget Sound lowland of west-central Washington, is bounded by Puget Sound on the east and by Hood Canal on the west, and covers an area of about 575 square miles. The peninsula encompasses all of Kitsap County, Mason County north of Hood Canal, and part of Pierce County west of Puget Sound. The peninsula is surrounded by saltwater, and the hydrologic setting is similar to that of an island. The study area is underlain by a thick sequence of unconsolidated glacial and interglacial deposits that overlie sedimentary and volcanic bedrock units that crop out in the central part of the study area. Twelve hydrogeologic units consisting of aquifers, confining units, and an underlying bedrock unit form the basis of the groundwater-flow model.

Groundwater flow on the Kitsap Peninsula was simulated using the groundwater-flow model, MODFLOW-NWT. The finite difference model grid comprises 536 rows, 362 columns, and 14 layers. Each model cell has a horizontal dimension of 500 by 500 feet, and the model contains a total of 1,227,772 active cells. Groundwater flow was simulated for transient conditions. Transient conditions were simulated for January 1985December 2012 using annual stress periods for 1985-2004 and monthly stress periods for 2005-2012. During model calibration, variables were adjusted within probable ranges to minimize differences between measured and simulated groundwater levels and stream baseflows. As calibrated to transient conditions, the model has a standard deviation for heads and flows of 47.04 feet and 2.46 cubic feet per second, respectively.

Simulated inflow to the model area for the 2005-2012 period from precipitation and secondary recharge was 585,323 acre-feet per year (acre-ft/yr) (93 percent of total simulated inflow ignoring changes in storage), and simulated inflow from stream and lake leakage was 43,905 acre-ft/yr (7 percent of total simulated inflow). Simulated outflow from the model primarily was through discharge to streams, lakes, springs, seeps, and Puget Sound $(594,595 \mathrm{acre}-\mathrm{ft} / \mathrm{yr} ; 95$ percent of total simulated outflow excluding changes in storage) and through withdrawals from wells (30,761 acre-ft/yr; 5 percent of total simulated outflow excluding changes in storage).
Six scenarios were formulated with input from project stakeholders and were simulated using the calibrated model to provide representative examples of how the model could be used to evaluate the effects on water levels and stream baseflows of potential changes in groundwater withdrawals, in consumptive use, and in recharge. These included simulations of a steady-state system, no-pumping and return flows, 15-percent increase in current withdrawals in all wells, 80-percent decrease in outdoor water to simulate effects of conservation efforts, 15-percent decrease in recharge from precipitation to simulate a drought, and particle tracking to determine flow paths.

Changes in water-level altitudes and baseflow amounts vary depending on the stress applied to the system in these various scenarios. Reducing recharge by 15 percent between 2005 and 2012 had the largest effect, with water-level altitudes declining throughout the model domain and baseflow amounts decreasing by as much as 18 percent compared to baseline conditions. Changes in pumping volumes had a smaller effect on the model. Removing all pumping and resulting return flows caused increased water-level altitudes in many areas and increased baseflow amounts of between 1 and 3 percent.

\section{Introduction}

Groundwater is the primary source of drinking water for most of the population of the Kitsap Peninsula (Lane, 2009). Consequently, as the population grows, so does the demand for groundwater. The quantity of usable groundwater likely is limited, however, mostly because of the peninsula geography and the potential for declines in water levels, decreases in groundwater discharge to streams, and seawater intrusion as groundwater usage increases.

At a series of public meetings held in 2009 to discuss the U.S. Geological Survey (USGS) Bainbridge Island groundwater study (Frans and others, 2011), water managers from the Public Utility District No. 1 of Kitsap County (KPUD) and several water purveyors on the Kitsap Peninsula expressed a desire for an integrated peninsula groundwater model for managing their water resources. The Kitsap Peninsula shares several characteristics with Bainbridge Island (fig. 1), and similar issues of limited groundwater 


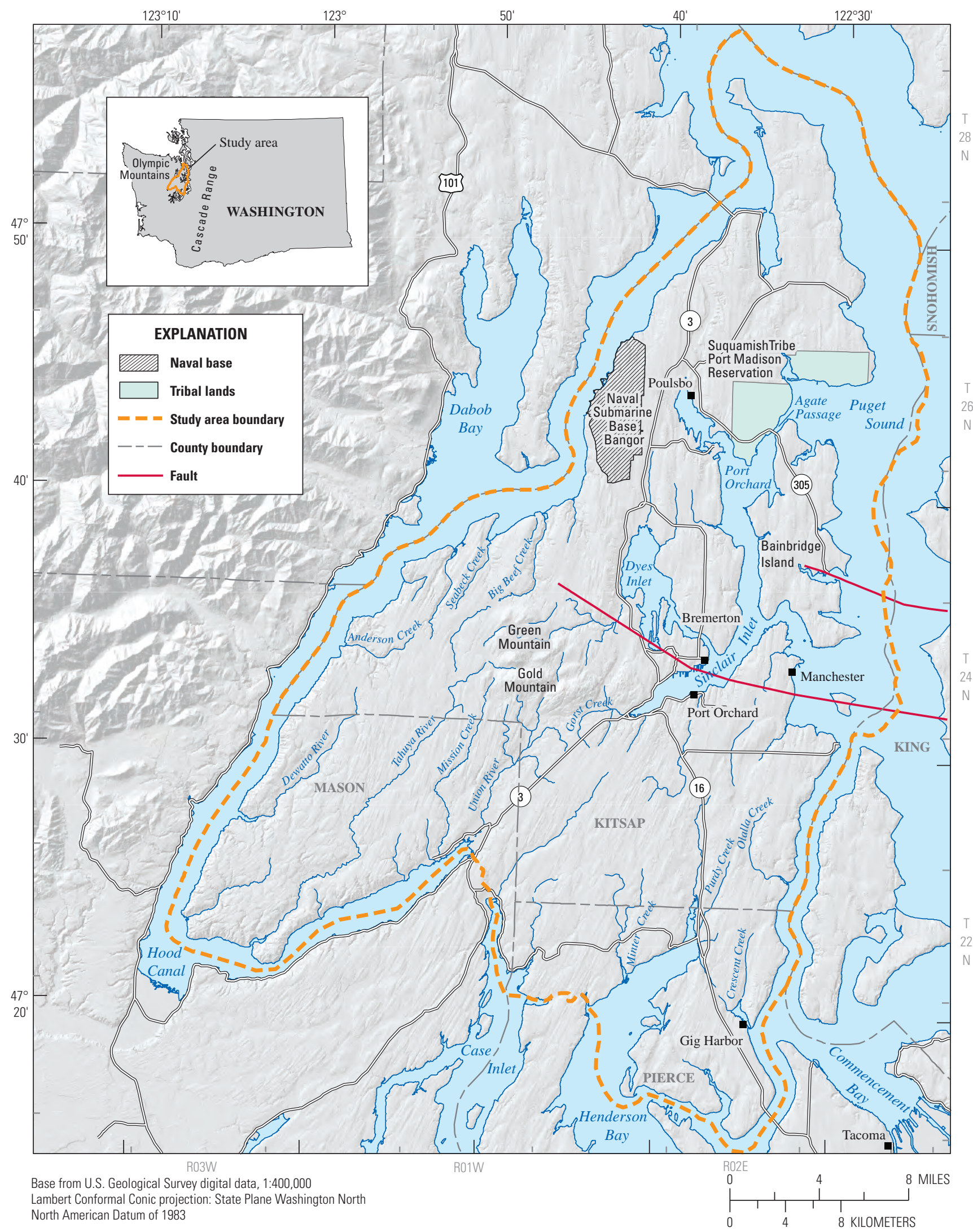

Figure 1. Location of the Kitsap Peninsula study area, west-central Washington. 
recharge because of overlying low-permeability glacial tills, increasing demands for groundwater supplies, and potential saltwater intrusion near coastal wells affect both areas. The geographic proximity of the two areas to each other also raises questions about potential connectivity between deeper aquifers on the peninsula and the island, with groundwater pumping practices in one area potentially affecting groundwater flow and storage in the other. The Bainbridge Island study was confined to the island and nearby parts of the peninsula. A larger model of the Kitsap Peninsula, extended to natural hydrologic barriers, would therefore provide a more physically realistic and representative rendering of the groundwater-flow system and regional groundwater supplies and would provide a valuable tool for water managers coordinating regional water-management plans. As a result of these discussions, the USGS and KPUD, with interlocal agreements between numerous other water purveyors ${ }^{1}$, began a project to characterize the groundwater-flow system of the Kitsap Peninsula. This project integrates Welch and others (2014) and various other available sources of information into a numerical groundwater-flow model that may be used to improve understanding of water resources in the Kitsap Peninsula.

\section{Purpose and Scope}

This report documents the development and calibration of a numerical model to simulate groundwater flow in the Kitsap Peninsula. The model can be used to assess the effects of groundwater withdrawals on groundwater levels and on streamflows during low-flow conditions. Additionally, this report provides assessments of numerical model performance in simulating measured hydrologic conditions, and a discussion of model limitations. Hydrogeologic information used to construct and calibrate the numerical model was based on the work of Welch and others (2014). Six scenarios were formulated and were simulated using the calibrated model to provide representative examples of how the model could be used to evaluate the effects on water levels and stream baseflows of potential changes in groundwater withdrawals, in consumptive use, and in recharge.

\section{Description of Model Area}

The Kitsap Peninsula is in the Puget Sound lowland of west-central Washington, is bounded by Puget Sound on the east and Hood Canal on the west, and covers an area of about $575 \mathrm{mi}^{2}$ (fig. 1). The peninsula encompasses all of Kitsap

${ }^{1}$ Silverdale Water District, West Sound Utility District, North Perry Water District, City of Bremerton, City of Port Orchard, City of Poulsbo, City of Gig Harbor, Manchester Water District, Washington Water Service, Suquamish Tribe, and Port Gamble S’Klallam Tribe.
County, part of Mason County north of Hood Canal, and part of Pierce County west of Puget Sound. The study area was selected to include hydrologic boundaries that could be used as model boundaries in numerical simulations of the groundwater flow system. The peninsula is surrounded by saltwater and has a hydrologic setting similar to that of an island. Many coastal areas are steep, with altitudes ranging from zero to more than $500 \mathrm{ft}$. Inland, slopes generally are moderate, and many areas are nearly flat. The Green and Gold Mountains in the central part of the peninsula, however, have altitudes greater than 1,700 ft. Glacial and interglacial deposits that constitute much of the subsurface of the study area are exposed in cliffs along many shorelines. The deposits consist primarily of alternating layers of glacial till, sand and gravel, and silt and clay. Bedrock, which underlies the glacial and interglacial deposits, ranges in depth from exposure at the land surface to an estimated 2,000 ft below land surface (Jones, 1996).

The study area is incised by rivers and streams that flow from the interior of the Kitsap Peninsula to Puget Sound and Hood Canal. Many rivers and streams flow year-round and are fed by springs and surface runoff after storms. Where cliffs are present along the coastline, springs and seeps discharge water directly onto the beach and into Puget Sound.

The study area has a temperate marine climate that is typical of the Puget Sound lowland, with warm, dry summers and cool, wet winters. Precipitation amounts are controlled largely by the Olympic Mountains to the west and the Cascade Range to the east, both of which impede the flow of humid air masses that are generated over the Pacific Ocean. The long-term average annual precipitation at Bremerton, Washington (fig. 1), in the central part of the study area, is $56.37 \mathrm{in} / \mathrm{yr}$ for 1981-2010; November and December are the wettest months, and July and August are the driest months. Precipitation at Bremerton during the 2 years of data collection for this study was 52.84 in. during 2011 and 69.66 in. during 2012. These amounts are 93.7 percent and 123 percent of the long-term average, respectively. Temperatures are mild throughout the year. The average monthly maximum temperature is $76.6^{\circ} \mathrm{F}$ in August, and the average monthly minimum is $34.5^{\circ} \mathrm{F}$ in December. At times, winter temperatures are sufficiently low for a few inches of snow to accumulate; however, snow accumulation typically is not significant or long lasting.

\section{Groundwater-Flow System}

This section describes the hydrogeologic units that constitute the groundwater-flow system in the model area and includes discussions of recharge, flow direction, discharge, exchange of water between the aquifer system and creeks, temporal fluctuations in groundwater levels, and water budget. This information was used to construct and calibrate the numerical model and is based on the work of Welch and others (2014). 
Numerical Simulation of the Groundwater-Flow System of the Kitsap Peninsula, West-Central Washington

\section{Geologic Setting}

The geology of the Kitsap Peninsula is a complex mix of glacial and nonglacial deposits that have been influenced by erosion. Four glaciations and three interglaciations are recognized in the Puget Sound lowland. For most of the Puget Sound lowland, the glacial deposits of the Vashon Stade of the Frasier Glaciation (the last major glacial advance) are exposed at the surface.

The ice of the Vashon Stade moved out of Canada about 18,000 years ago and split into two lobes. The Puget lobe flowed south into the Puget Sound lowland, occupied all the lowland, and was about 3,000 ft thick near Seattle and about $6,000 \mathrm{ft}$ thick near the United States-Canada border. The glacier began retreating about 14,500 years ago.

Three types of deposits typically are associated with continental glaciation: advance outwash, till, and recessional outwash. As the glacier flowed south, streams and melting ice at the front of the glacier deposited sediments known as advance outwash. Advance outwash units typically are coarse grained and make productive aquifers. As the glacier continued its advance, the advance outwash was covered with glacial till. Glacial till consists of unsorted rocks that range in size from clay to boulders that are transported by the advancing glacier. Till is considered to be a confining unit due to its poor hydraulic permeability, which results from the abundance of fine-grained clays and silts and the overburden stress of thousands of feet of overlying ice. Streams emanating from the glacier deposited recessional outwash over the top of the till as the glacier melted and retreated. Like the advance outwash, recessional outwash is coarse grained and typically forms aquifer units.

Each major glacial period was followed by an extended interglacial period where fluvial, lacustrine, bog, and marsh deposition dominate. Interglacial deposits typically consist of clay, silt, or discontinuous lenses of sand and gravel or peat. Underlying these unconsolidated glacial and interglacial deposits are Tertiary bedrock units consisting primarily of sedimentary claystone, siltstone, sandstone, beds of coal, and volcanic rocks. Since the end of the last glacial period, erosion has been the dominant geomorphic process affecting the peninsula. Alluvial sediments, typically sands and gravels, have been deposited by streams in valleys and marsh deposits formed in poorly drained, low-lying areas.

The study area is bisected by a major fault zone running east-west from the southern tip of Bainbridge Island across to the northern side of Green and Gold Mountains (fig. 1). On the southern side of the fault zone at the southern end of Bainbridge Island, on the opposite shore north of Manchester and at the entrance to Dyes Inlet, a thick sequence of Tertiary marine sedimentary rock is either exposed at the surface or overlain by glacial deposits (Sceva, 1957). This bedrock unit, known as the Blakely Formation, consists of sandstone, siltstone, claystone, and conglomerate. To the west of Bremerton, at Green and Gold Mountains, the exposed bedrock primarily is basalt.

\section{Hydrogeologic Units}

Geologic units were grouped into hydrogeologic units, comprising aquifers and confining units, on the basis of lithologic (depositional facies, grain size, and sorting) and hydrologic (hydraulic conductivity and unit geometry) characteristics. Welch and others (2014) delineated 12 hydrogeologic units in the model area listed from upper to lower:

- Vashon recessional aquifer (Qvr),

- Vashon till confining unit (Qvt),

- Vashon advance aquifer (Qva),

- Upper confining unit (QC1),

- Permeable interbeds (QClpi), included locally within QC1,

- Sea-level aquifer (QA1),

- Middle confining unit (QC2),

- Glaciomarine aquifer (QA2),

- Lower confining unit (QC3),

- Deep aquifer (QA3),

- Basal confining unit (QC4), and

- Bedrock (BR).

Glacial deposits generally are heterogeneous, and although a glacial aquifer may be composed primarily of sand or gravel, locally it can contain varying amounts of clay or silt. Similarly, a confining layer composed predominantly of silt or clay can contain local lenses of coarse material. These variations in lithology may influence the occurrence and movement of groundwater at a scale that is likely too small to be adequately represented by the regional-scale groundwater-flow model constructed for this study. Local-scale variability in the distribution of glacial depositional facies often results in the formation of spatially discontinuous units of varying thickness. Therefore, some units are not spatially contiguous, and unit thickness may vary considerably over short distances throughout the model area (Welch and others, 2014, figs. 5-16).

Within the study area, aquifers primarily are composed of glacial outwash but also may include coarse-grained interglacial deposits. The confining units primarily are composed of fine-grained interglacial deposits but also include glacial till or glaciolacustrine deposits. Unconsolidated glacial and interglacial aquifer and confining units are underlain by low-permeability Tertiary bedrock units, which Jones (1999) described as the basement confining unit.

Unconfined and confined conditions are present in the groundwater-flow system and affect the movement and storage of groundwater. Unconfined conditions occur when the upper surface of the saturated zone (water table) is at atmospheric pressure and the water table is free to fluctuate (rise and decline, filling and draining pore space, respectively), in 
response to changes in groundwater recharge and discharge. A confined, or artesian, aquifer is one that is overlain by another hydrogeologic unit and has a hydraulic head above the top of the aquifer. Changes in fluid pressure or head under confined conditions in response to groundwater recharge and discharge are partially governed by the compressibility of the fluid and the skeletal matrix of the unit and do not result in filling or draining pore space.

\section{Hydraulic Conductivity}

Horizontal hydraulic conductivity was estimated for the hydrogeologic units using specific-capacity data from drillers' logs and results of available aquifer tests (Welch and others, 2014). Specific-capacity data were compiled and analyzed for 902 wells that had a driller's log containing discharge rate, time of pumping, drawdown, static water level, well-construction data, and lithologic descriptions. Aquifer tests results were available for 87 public water supply wells. Median values of estimated hydraulic conductivity for the aquifers (table 1) are similar in magnitude to values compiled by Vaccaro and others (1998) for the Puget Sound lowlands and to values reported by Freeze and Cherry (1979) for similar materials. Median values of estimated hydraulic conductivities (table 1) probably are biased too high because the specific capacity data and aquifer tests were obtained from wells that are preferentially open to the major water-producing aquifers and water-producing coarse material rather than finer grained material in other hydrogeologic units in the model area. These data, therefore, likely represent the more productive zones in these units and not the entire unit.

Table 1. Summary of horizontal hydraulic conductivities estimated from specific-capacity data and aquifer tests, by hydrogeologic unit, Kitsap Peninsula, west-central Washington.

\begin{tabular}{lrlrr}
\hline \multicolumn{1}{c}{ Hydrogeologic unit } & $\begin{array}{c}\text { Number } \\
\text { of wells }\end{array}$ & \multicolumn{3}{c}{$\begin{array}{c}\text { Hydraulic conductivity } \\
\text { (feet per day) }\end{array}$} \\
\cline { 3 - 6 } & \multicolumn{3}{c}{ Minimum Median Maximum } \\
\hline \multicolumn{2}{c}{ Estimated from specific-capacity data } \\
\hline Qva, Vashon advance aquifer & 335 & 0.335 & 51 & 3,527 \\
QC1pi, permeable interbeds & 62 & 0.35 & 27 & 663 \\
QA1, sea-level aquifer & 395 & 0.2 & 38 & 6,111 \\
QA2, glaciomarine aquifer & 82 & 0.18 & 35 & 1,661 \\
QA3, deep aquifer & 22 & 0.75 & 32 & 1,993 \\
BR, bedrock & 6 & 0.004 & 2.3 & 158 \\
\hline \multicolumn{2}{c}{ Estimated from aquifer tests } & & \\
\hline Qva, Vashon advance aquifer & 11 & 10 & 94 & 2,339 \\
QC1pi, permeable interbeds & 4 & 91 & 181 & 334 \\
QA1, sea-level aquifer & 30 & 2 & 64 & 891 \\
QA2, glaciomarine aquifer & 28 & 8 & 72 & 602 \\
QA3, deep aquifer & 14 & 6 & 42 & 2,406 \\
\hline
\end{tabular}

\section{Recharge}

Because precipitation is the dominant source of water that recharges groundwater in the model area, it is reasonable to expect the volume of recharge to vary with the volume of precipitation. However, other factors, such as the permeability of surficial hydrogeologic units and land-cover characteristics, also determine the magnitude of recharge. The distribution of recharge from precipitation in the model area was estimated by applying precipitation-recharge relations (Welch and others, 2014) based on four separate regression equations developed for areas in the Kitsap Peninsula by Bidlake and Payne (2001). The four regression equations compute annual recharge to aquifers and confining units in areas with or without tree cover and monthly recharge amounts were then estimated from the annual amount using estimates of monthly fractional drainage from the root zone (Bidlake and Payne, 2011). The groundwater-flow system in the study area receives about 523,680 acre-ft or about 17 in. of recharge from precipitation during an average year (Welch and others, 2014). Groundwater recharge also occurs through return flows from septic systems and outdoor (irrigation) use; return-flow estimates used in the groundwater-flow model are discussed in the section, "Specified-Flux Boundaries."

\section{Discharge}

Groundwater in the model area discharges to streams, lakes, springs, marshes, and along coastal and river valley bluffs; as evaporation and transpiration of shallow groundwater; as submarine seepage to Puget Sound; and as withdrawals from wells. Groundwater discharge sustains the late-summer and early-autumn streamflow (baseflow) in the model area. The groundwater discharge to streams on the peninsula for 2012 was estimated to be $629 \mathrm{ft}^{3} / \mathrm{s}$ (455,550 acre-ft/yr) (Welch and others, 2014). Submarine seepage to Puget Sound was computed as a residual component in the water budget (see section, "Water Budget”).

Groundwater withdrawals from wells in 2012 were estimated to be 30,866 acre-ft (Welch and others, 2014). This represents the sum of all water pumped for public supply and domestic purposes, fish hatcheries, and golf course irrigation. This quantity represents gross withdrawals and does not include return flows from septic systems and outdoor (irrigation) use.

\section{Groundwater-Level Fluctuations}

Seasonal changes in groundwater levels that follow a typical pattern for shallow wells in western Washington were observed in many wells in the model area (Welch and others, 2014). Water levels rose in autumn and winter when precipitation and river stage were high and declined during spring and summer when precipitation and river stage 
were low. The peak groundwater levels tend to lag behind the peak streamflow by a few months, reflecting the transmission and storage characteristics of the groundwater system. Water levels in wells completed in the unconsolidated hydrogeologic units varied seasonally from less than 1 to about $20 \mathrm{ft}$. The largest fluctuation in water level (33 ft) during the monitoring period was measured in a well completed in the bedrock unit.

\section{Water Budget}

An approximate groundwater budget for 2012, which assumed steady-state conditions (Welch and others, 2014) is presented in table 2. For 2012, virtually all the groundwater recharge (97 percent) derived from precipitation, and only 3 percent was from return flows. Most of this recharge (66 percent) discharged to streams, and only about 4 percent was withdrawn from wells. The remaining groundwater recharge (30 percent) left the groundwater system as discharge to Hood Canal and Puget Sound.

The estimated magnitude of discharge to Hood Canal and Puget Sound is uncertain because it incorporates all the inaccuracies in the other water-budget component estimates, and no attempts have been made to measure it directly.

\section{Numerical Simulation of the Groundwater-Flow System}

Groundwater flow on the Kitsap Peninsula was simulated using the U.S. Geological Survey modular three-dimensional finite-difference groundwater-flow model, MODFLOW-NWT (Niswonger and others, 2011). MODFLOW-NWT is a computer program that numerically solves the three-dimensional groundwater-flow equation for a porous medium using the finite-difference method. The modular design of MODFLOW-NWT uses packages to represent groundwater-flow system processes, such as recharge, groundwater flow, discharge, and interactions between the aquifer and surface-water bodies. The model described in this report was developed to simulate transient conditions. Transient groundwater flow represents a dynamic system in which variable inflows, outflows, and groundwater storage change with time. The simulation of transient conditions incorporates yearly and monthly variations in recharge, discharge, and other groundwater-flow system processes.

\section{Model Grid and Layering}

The MODFLOW program uses data sets that describe the hydrogeologic units, recharge, and discharge of the groundwater-flow system, and calculates hydraulic heads at discrete points and flow within the model domain. The program requires that the groundwater-flow system be subdivided, vertically and horizontally, into model cells. The
Table 2. Estimated annual water budget for the groundwater system of the Kitsap Peninsula, west-central Washington, 2012.

[Values may not sum to 100 due to rounding]

\begin{tabular}{|c|c|c|}
\hline Water-budget component & Acre-feet & Percent \\
\hline \multicolumn{3}{|l|}{ Groundwater recharge } \\
\hline From precipitation & 664,610 & 97 \\
\hline From return flows & 22,122 & 3 \\
\hline Total & 686,732 & 100 \\
\hline \multicolumn{3}{|l|}{ Fate of recharge } \\
\hline Discharge to streams & 455,550 & 66 \\
\hline Other natural discharge & 200,316 & 30 \\
\hline Withdrawals from wells & 30,866 & 4 \\
\hline Total & 686,732 & 100 \\
\hline
\end{tabular}

hydraulic properties of the material in each cell are assumed to be homogeneous. The study area was subdivided by a horizontal grid of 362 columns and 536 rows; cells are a uniform $500 \mathrm{ft}$ per side (fig. 2). The large cell size and uniform grid spacing were selected to reflect the regional scale of this study.

The study area was subdivided into 14 vertical model layers. The hydrogeologic units delineated by Welch and others (2014) were used to represent the three-dimensional hydrogeologic framework and vertical layering in the model. Owing to the complicated geologic history of the area, most hydrogeologic units are not spatially contiguous throughout the model area, and unit thicknesses vary considerably over short distances. Each hydrogeologic unit was assigned a principal model layer that most closely corresponds to the stratigraphic position of the unit in the aquifer system. The extents of active cells in each layer are outlined in figures $3 \mathrm{~A}-\mathrm{M}$. The thickness of each layer varies spatially and corresponds with the thickness mapped by Welch and others (2014). With the exception of the bedrock unit and the upper confining unit, each unit is represented by a single model layer, although overlying or underlying units can occupy a model layer in areas where the primary hydrogeologic unit assigned to the layer is absent. The upper confining unit is represented by layers 4 and 6 in the model as it is bisected by the semi-permeable interbeds aquifer (QC1pi, layer 5) in some places. The bedrock unit was divided into two units to account for an assumed depth dependence of secondary permeability features (joints and fractures). These features are assumed to remain "open" and facilitate groundwater movement within the upper $200 \mathrm{ft}$ of unit thickness. Compressive forces in deep parts of these units (greater than $200 \mathrm{ft}$ ) are assumed to prevent the development and (or) reduce the "open dimension" of secondary permeability features; resulting in a reduction or elimination of groundwater flow through these features. The bottom of the model (bottom of layer 14) was set at a constant altitude of $-2,836 \mathrm{ft}$ and is specified as a no-flow boundary. 


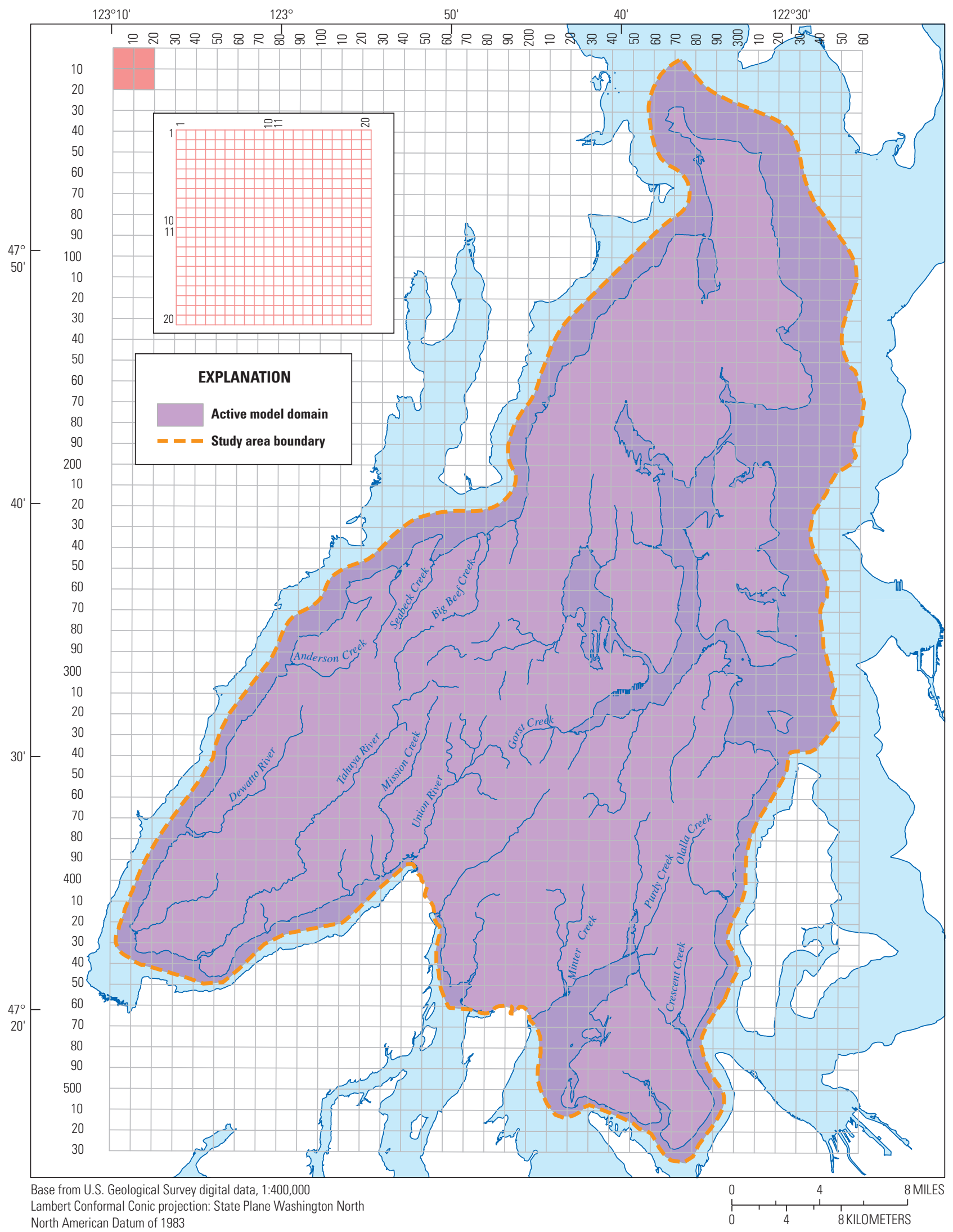

Figure 2. Location and extent of the groundwater model grid, west-central Washington. The insert depicts the detailed horizontal discretization for the first 20 rows and columns of the grid. 


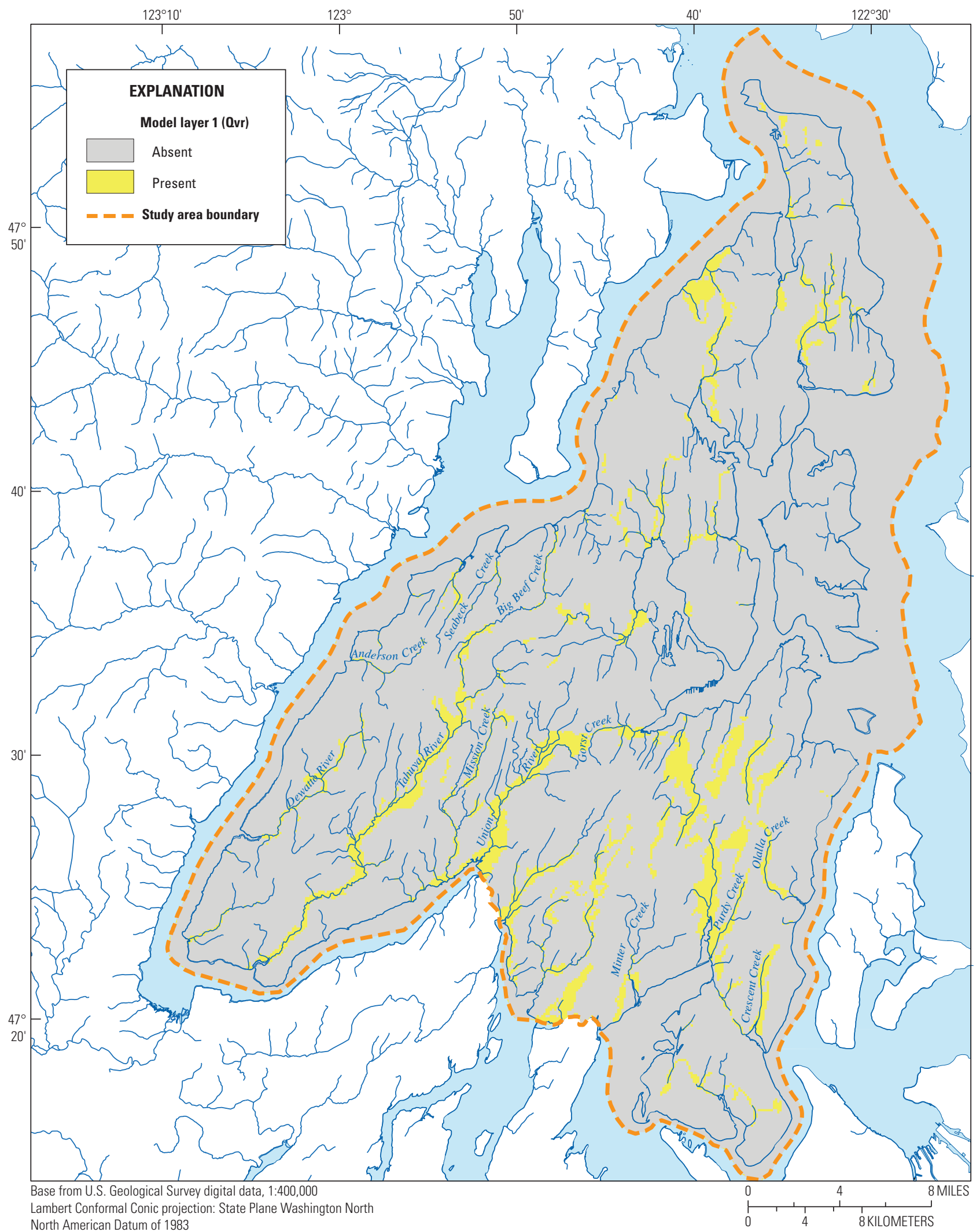

A. Model layer 1—Vashon recessional aquifer (0vr).

Figure 3. Areal extent of model layers, Kitsap Peninsula, west-central Washington. 


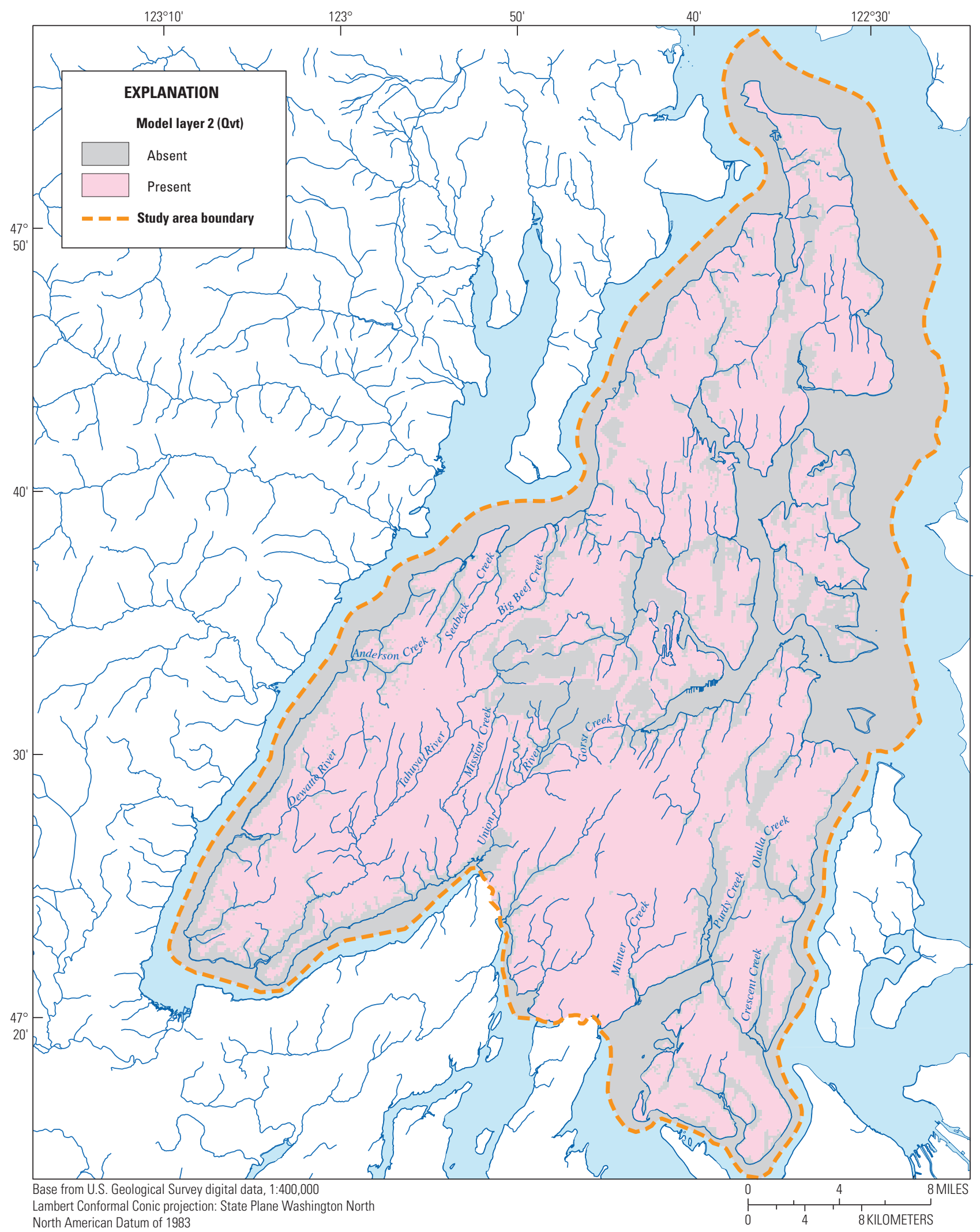

B. Model layer 2-Vashon till confining unit (Qvt).

Figure 3.-Continued 


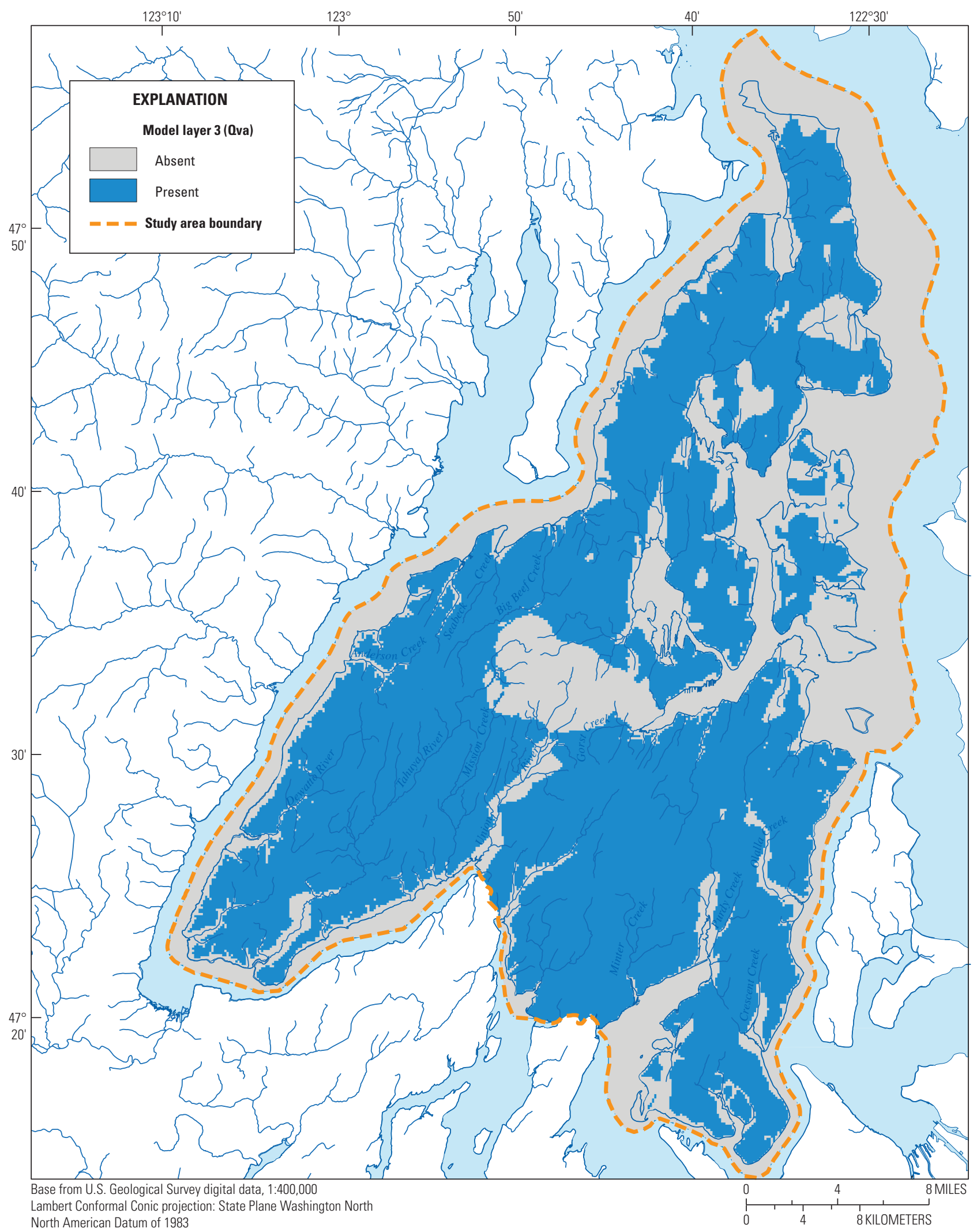

C. Model layer 3-Vashon advance aquifer (Qva).

Figure 3.-Continued 


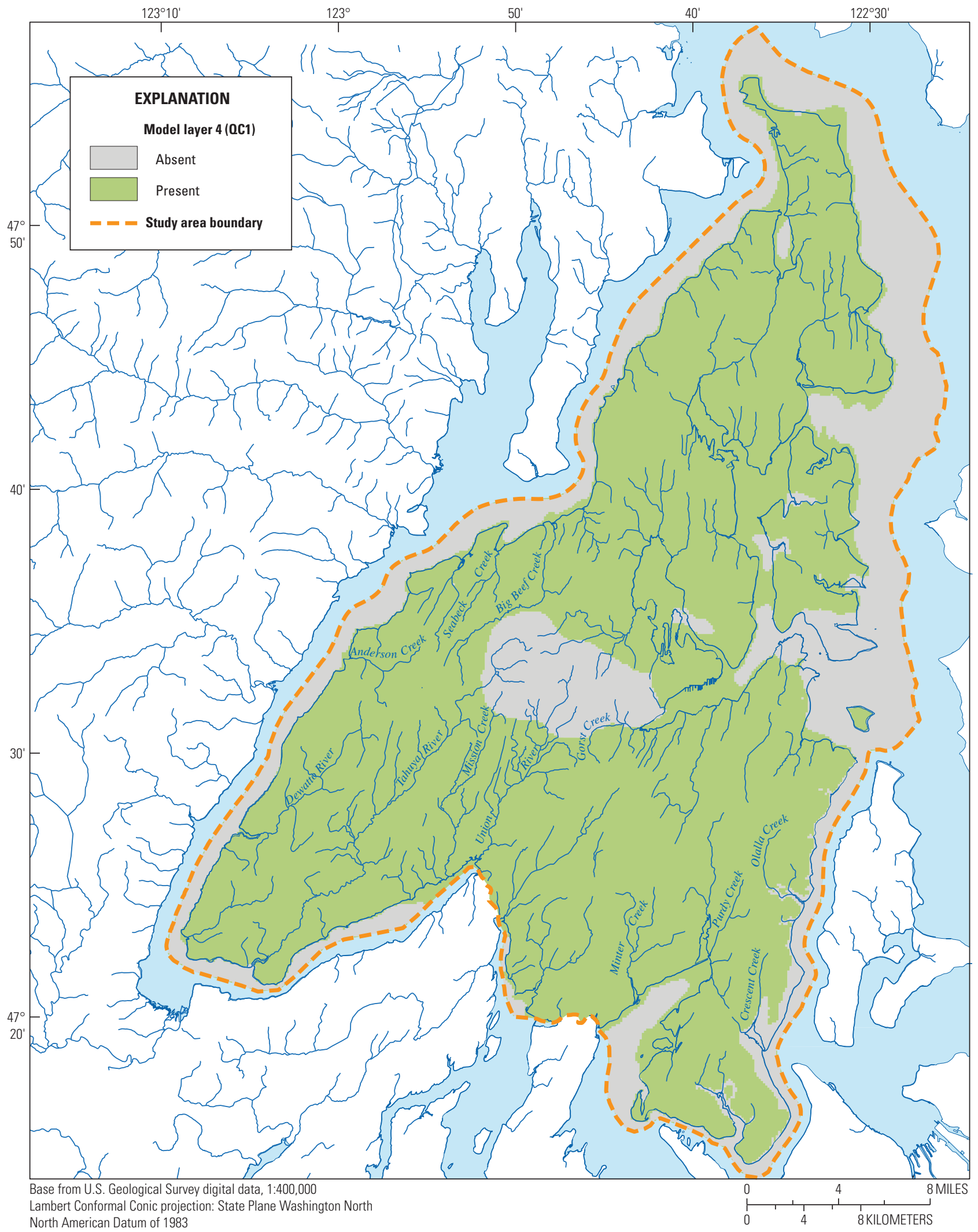

D. Model layer 4-upper confining unit (OC1).

Figure 3.-Continued 


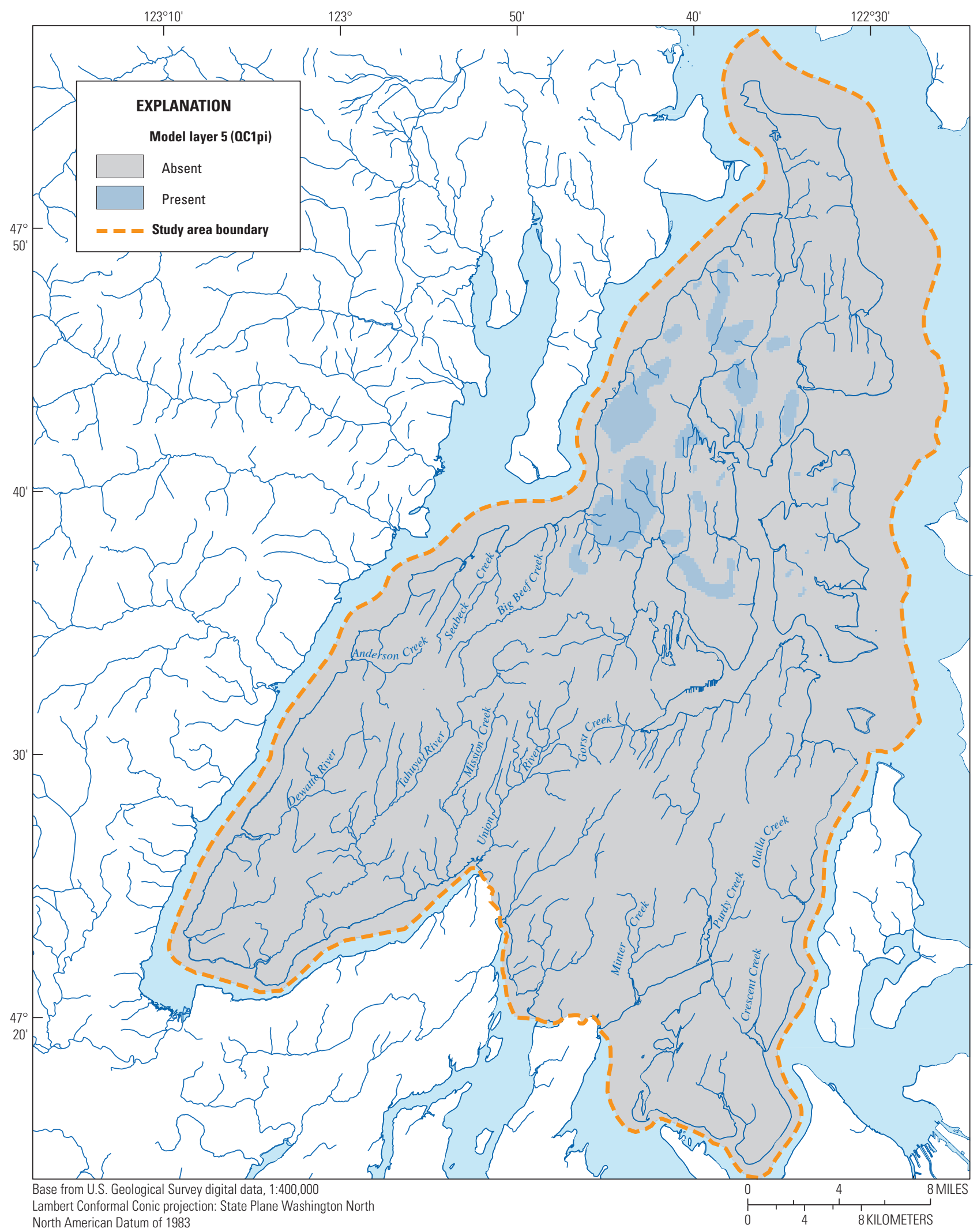

E. Model layer 5-permeable interbeds (OC1pi), included locally within OC1.

Figure 3.-Continued 


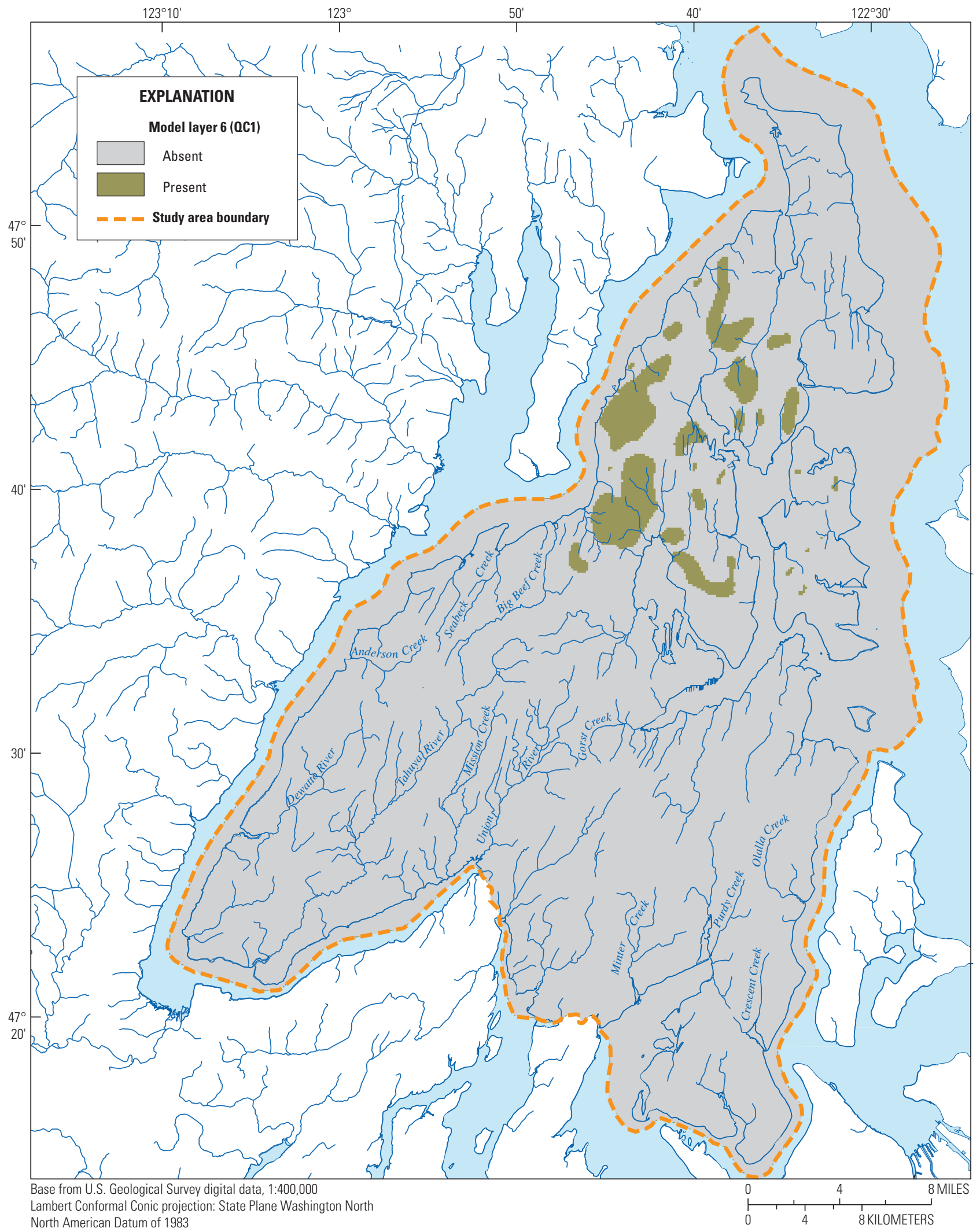

F. Model layer 6-confining unit (OC1).

Figure 3.-Continued 


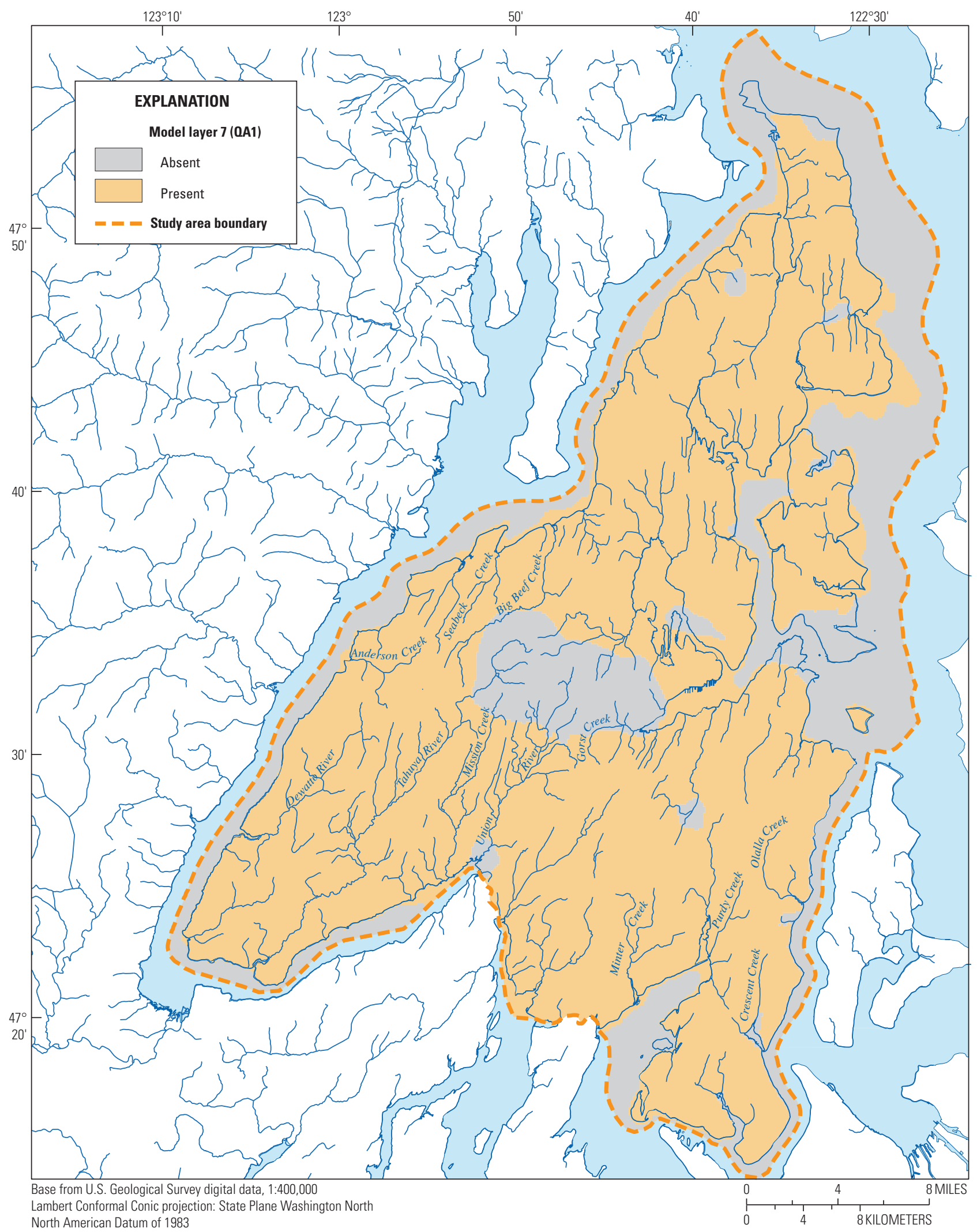

G. Model layer 7—sea level aquifer (QA1).

Figure 3.-Continued 


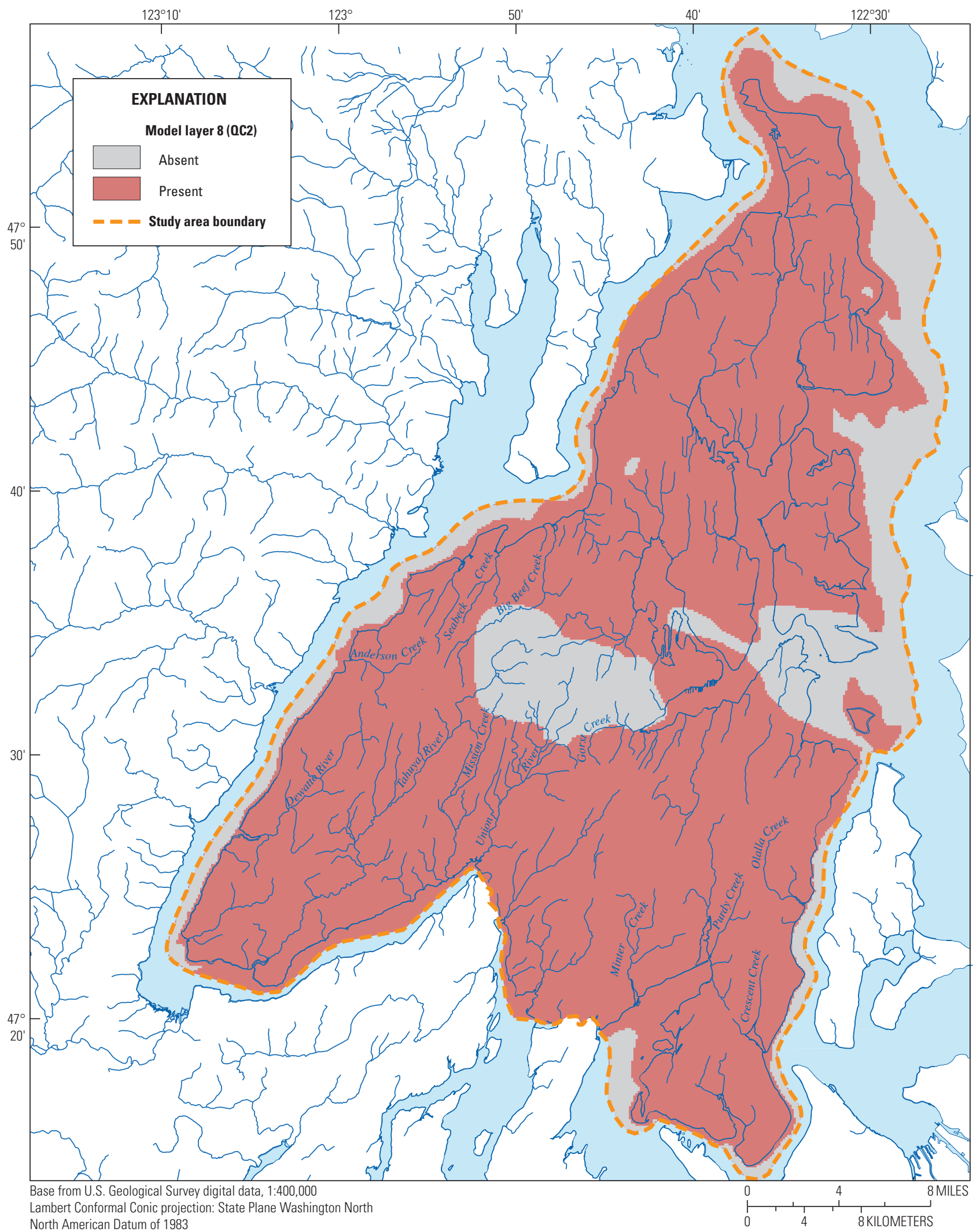

North American Datum of 1983

H. Model layer 8-middle confining unit (OC2).

Figure 3.-Continued 


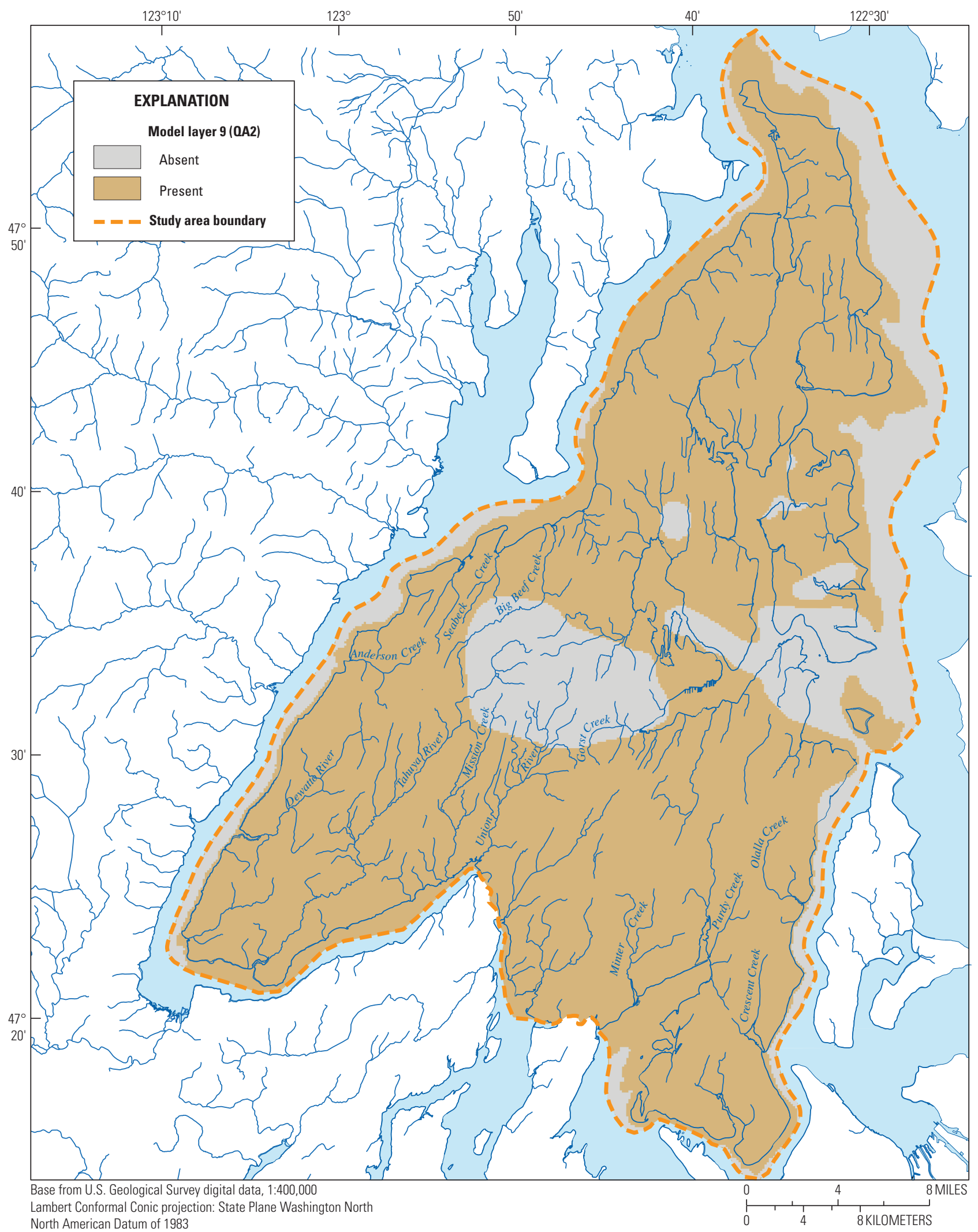

I. Model layer 9-glaciomarine aquifer (QA2).

Figure 3.-Continued 


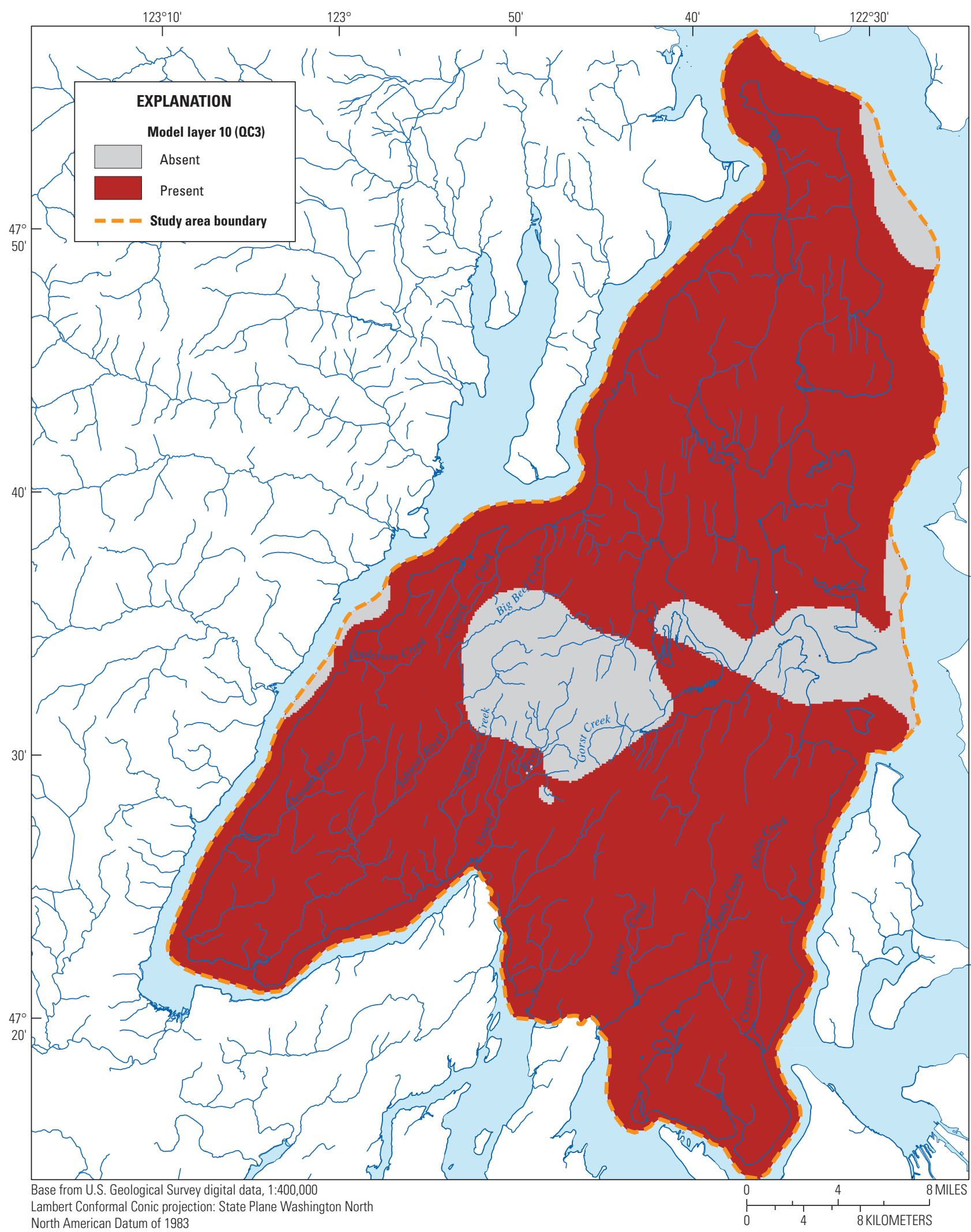

J. Model layer 10-lower confining unit (QC3).

Figure 3.-Continued 


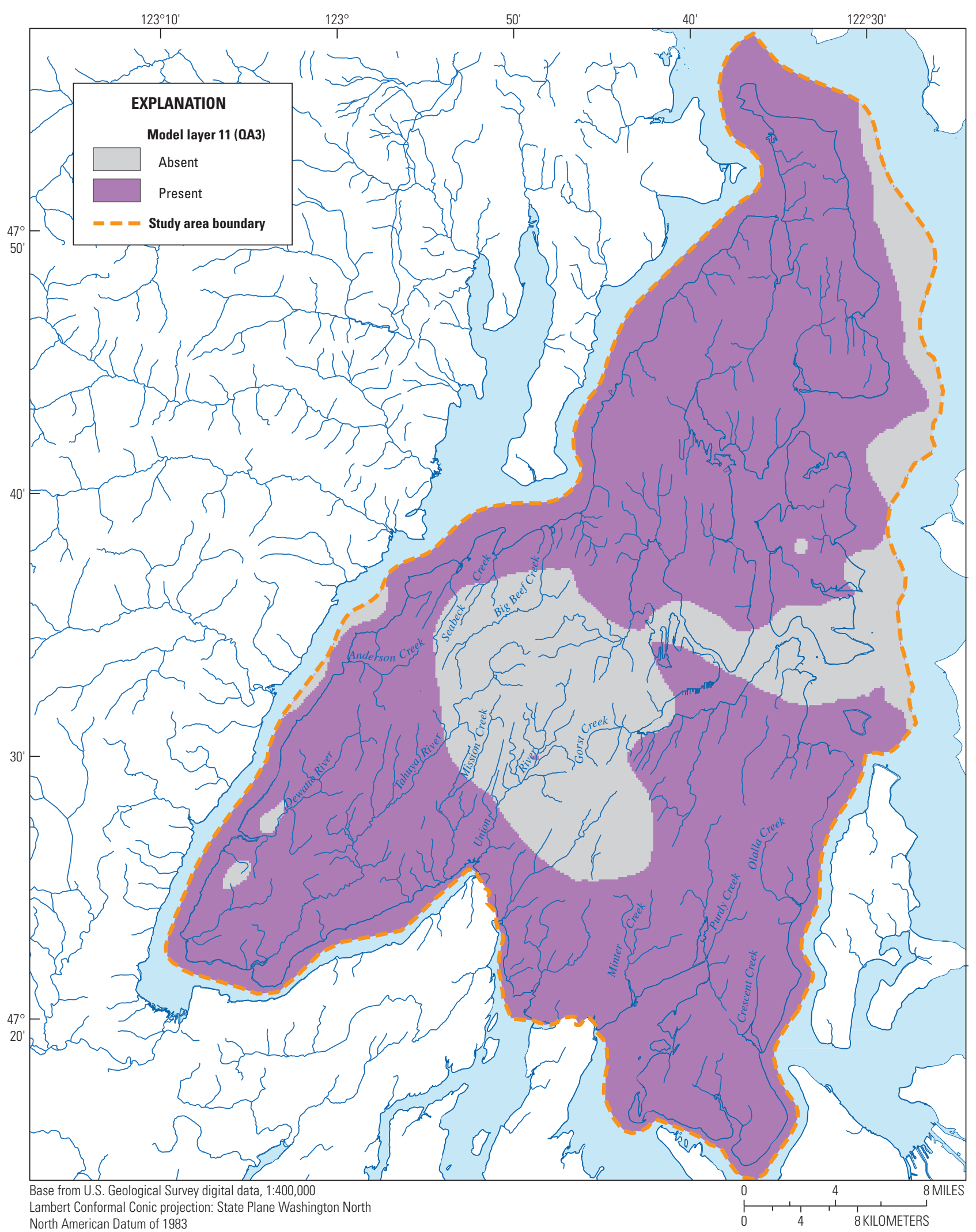

K. Model layer 11—deep aquifer (QA3).

Figure 3.-Continued 


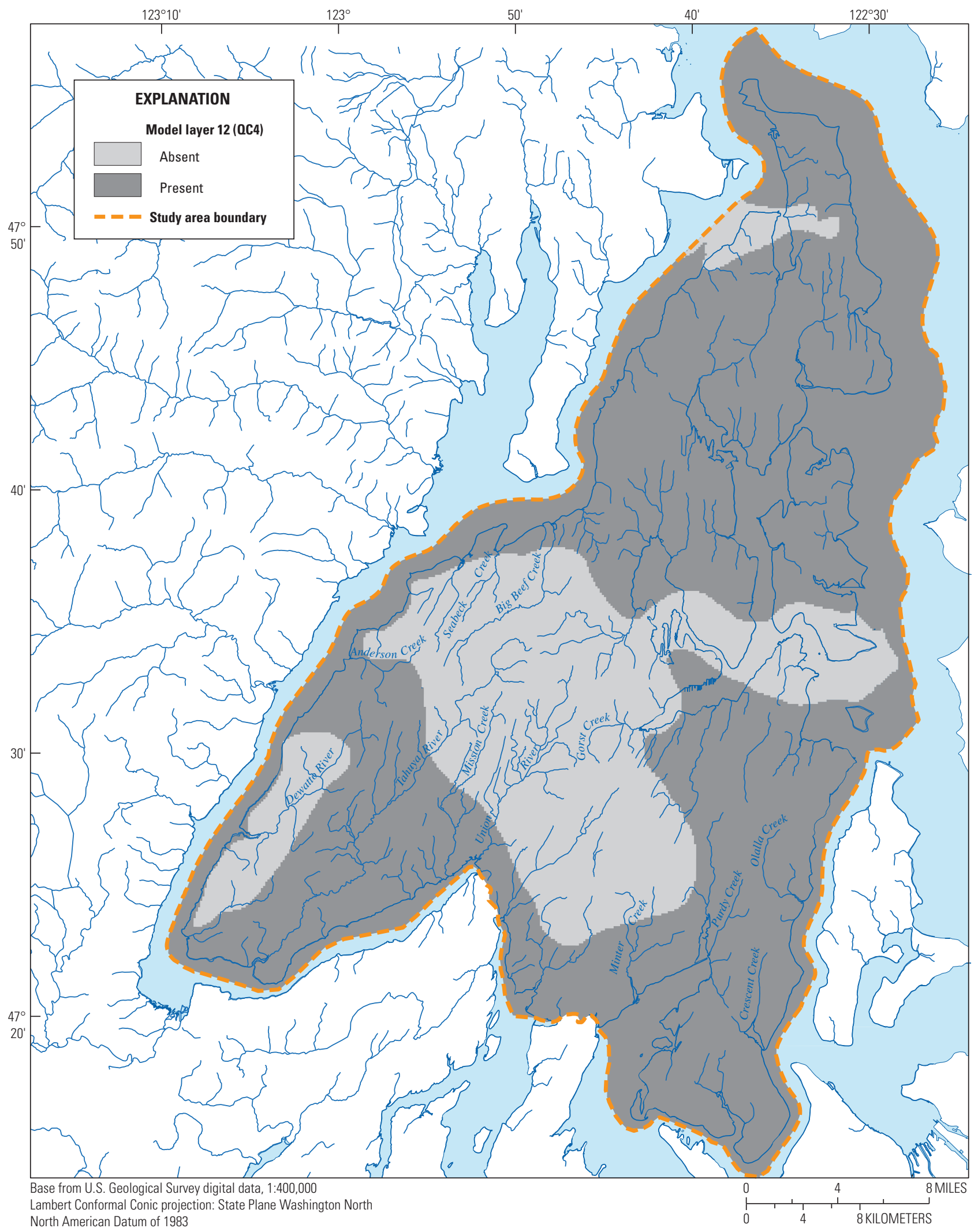

L.. Model layer 12-Basal confining unit (QC4).

Figure 3.-Continued 


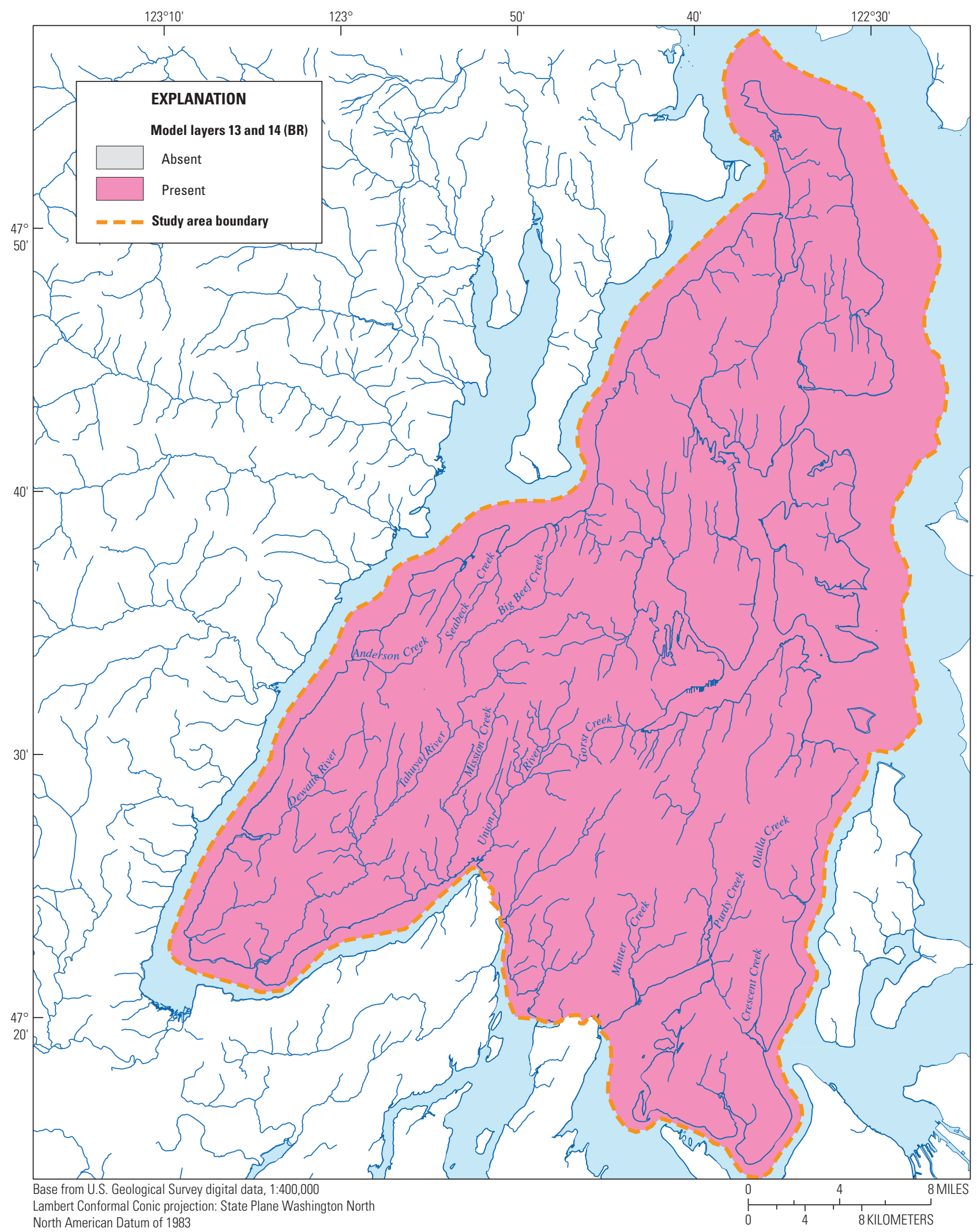

M. Model layers 13 and 14-bedrock (BR).

Figure 3.-Continued 
The model requires that all layers be present in all active cells in the model. In order to ensure proper model operation, where the hydrogeologic units constituting a model layer were absent, the layer was altered. A 1-ft thickness was assigned to the model layer and the specified hydraulic properties were changed to represent hydraulic conductivities of the layer below. This results in the simulated flow passing through the "altered" layer as if it were part of an adjacent model layer. All model layers were simulated as convertible between confined and unconfined conditions.

\section{Temporal Discretization}

The transient simulation period (January 1985December 2012) was divided into 116 stress periods to represent temporal variations in recharge, discharge, and other groundwater-flow system processes. Annual stress periods were used from 1985 to 2004, and monthly stress periods were used from January 2005 to December 2012. Each stress period consists of only one time step to coincide with the frequency of data collected in the field, because smaller time steps were not necessary for stable operation of the model. The method for developing initial conditions for the model used a 22-year "lead-in" period (January 1985-December 2006) to establish water levels in the model for use in the beginning of the calibration period (January 2007-December 2012). Temporal discretization of the "lead-in" period consisted of: an initial steady-state condition stress period, followed by twenty 1-year transient stress periods and 24 monthly transient stress periods. Each of the "lead-in" stress periods simulated recharge based on precipitation records for each period. Well withdrawals (and return flows) were simulated using the same spatial distribution of wells used in the transient calibration period.

\section{Boundary Conditions}

Boundary conditions define the locations and manner in which water enters and exits the active model domain. Conceptually, water enters the aquifer system as recharge from precipitation (rainfall and snowmelt) and exits the system as streamflow, submarine groundwater discharge, and groundwater pumpage. The boundaries of the model coincide as much as possible with natural hydrologic boundaries. Three types of model boundaries were used: (1) no-flow boundaries (bottom of model and groundwater divides), (2) head-dependent flux boundaries (streams, drains, and general-head boundaries), and (3) specified-flux boundaries (pumpage and recharge).

\section{No-Flow Boundaries}

The model boundaries that coincide with the center of Hood Canal and Puget Sound are simulated as no-flow boundaries because they are assumed to be groundwater divides. No flow-boundaries also occur between the ends of Hood Canal and Case Inlet and between Case Inlet and Henderson Bay as these boundaries are parallel to the presumed direction of groundwater flow.

\section{Head-Dependent Flux Boundaries}

\section{Streams}

The exchange of groundwater and surface water is an important hydrologic process on the Kitsap Peninsula, and the model was constructed to capture this process to the best extent possible. Rivers and creeks were simulated using the MODFLOW Streamflow-Routing (SFR) Package to route streamflow and calculate river-aquifer exchanges (Niswonger and Prudic, 2005). The model has 317 simulated stream segments that are coincident with the underlying MODFLOW cells (U.S. Geological Survey, 2014); the locations of the simulated stream cells are shown in figure 4.

The exchange of water between streams and groundwater is controlled by the difference in the groundwater level and stream stage in each cell, and by the hydraulic properties of the streambed at the river-aquifer boundary in each cell, which is represented in the model by a user-specified streambed conductance term. The depth of each stream within each reach was computed by SFR using Manning's equation for open channel flow assuming a wide rectangular channel. Average stream depth and stream width for the cross sections were based on mean annual streamflow using regression equations determined by Magirl and Olsen (2009) and data from the USGS National Hydrography Dataset (U.S. Geological Survey, 2014).

The simulated quantity of water moving between the groundwater and surface-water systems is equal to the product of streambed conductance and the simulated head difference between the stream and underlying model hydrogeologic units. Initial values of streambed conductance were based on stream length (determined using geographic information systems) and width (Magirl and Olsen, 2009), estimated streambed hydraulic conductivity, and streambed thickness. Streambed thickness was set to $1 \mathrm{ft}$ for all stream reaches. The model internally multiplies the hydraulic conductivity value (feet per day) by the stream reach length (feet) and wetted width (feet), divided by the streambed thickness (feet), resulting in the streambed conductance (square foot per day). For routing streamflow, a constant value of 0.04 was used for Manning's coefficient. 


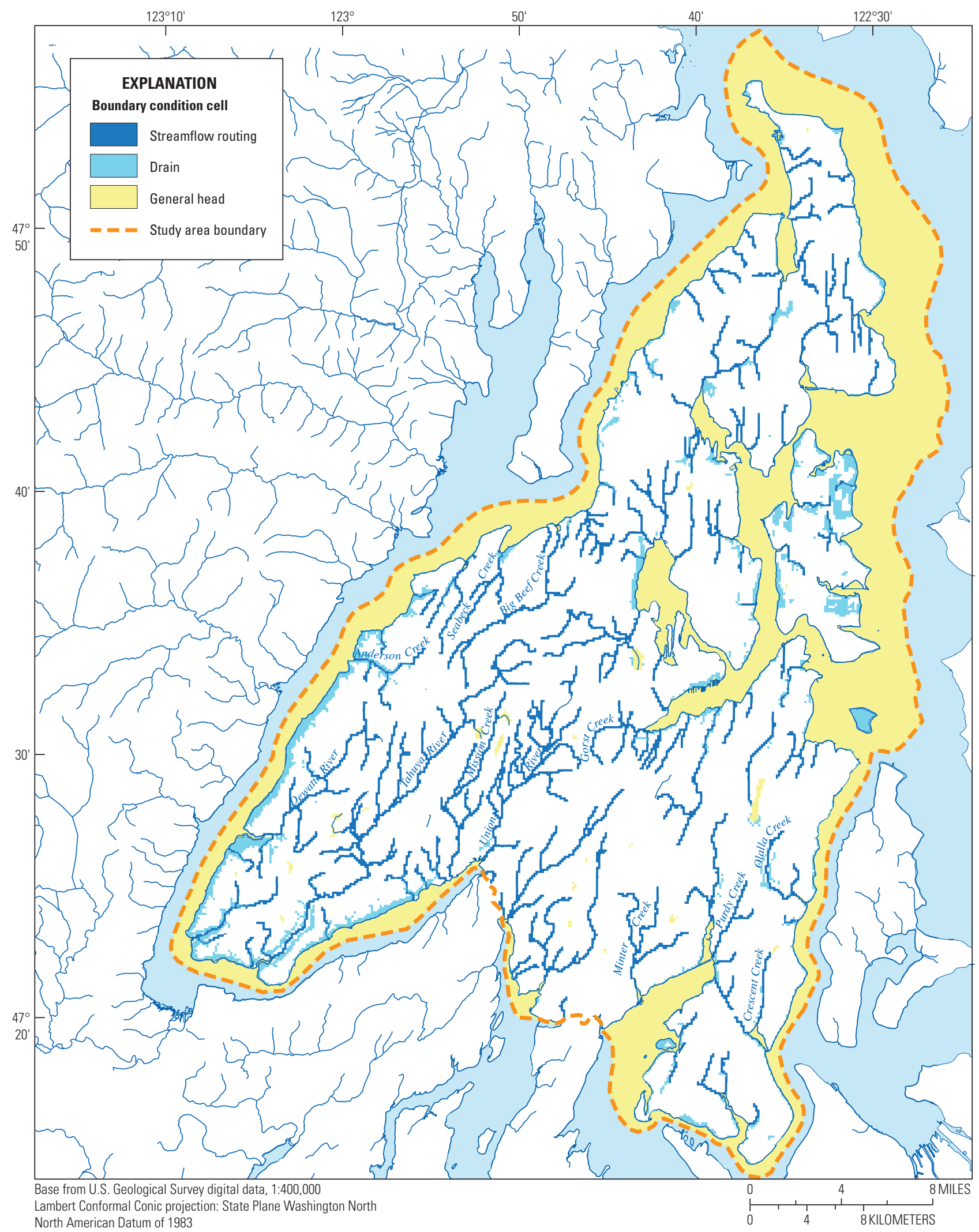

Figure 4. Locations of model streamflow-routing, drain, and general head boundary condition cells, Kitsap Peninsula, west-central Washington. 


\section{General-Head Boundaries}

The General-Head Boundary (GHB) Package of MODFLOW was used to simulate subsurface discharge from the lakes to the underlying aquifers and the exchange of water between the aquifer system and Puget Sound (fig. 4). Representation of the lakes in this way allows flow into and out of a lake cell in proportion to the difference between the head in the cell and the specified head of the lake. The specified lake stages were determined from USGS 1:24,000-scale topographic maps because no data about changes in lake stages were available. The specified stage for cells in Puget Sound were set to fresh-water equivalent heads at the seafloor. Freshwater equivalent heads were set equal to 0.023 times the depth of saltwater at the cell (van Heeswijk and Smith, 2002, p. 39).

\section{Drain Boundaries}

Drains (using the Drain Package of MODFLOW) were placed along the shorelines of the model to simulate springs and groundwater seeps that occur throughout the area in bluffs along the coast. Drains also were placed in areas where low hydraulic conductivity units outcrop at the surface to simulate the routing of recharge in those areas to nearby streams. The altitude of these drain cells was set to the land-surface altitude.

\section{Specified-Flux Boundaries}

Two types of specific fluxes were simulated in the model: (1) recharge and (2) groundwater withdrawals (pumpage).

\section{Recharge}

The Recharge Package (RCH) of MODFLOW was used to simulate groundwater recharge from precipitation, and the Well Package was used to simulate return flows from septic systems and outdoor (irrigation) use. Recharge (in units of feet per day) is applied as a specified flux to the uppermost active cell. Precipitation is the dominant source of water recharging the groundwater system in the study area, and variations in recharge are related to spatial and temporal variations in precipitation, the permeability of surficial hydrogeologic units, and landcover characteristics. The distribution of annual recharge from precipitation in the study area (Welch and others, 2014) was estimated by applying precipitation recharge relations based on regression equations developed for areas in Puget Sound, Washington (Bidlake and Payne, 2001) that incorporate the effects of surficial hydrogeology and tree canopy characteristics. Monthly recharge amounts were estimated using the monthly fractional drainage from the root zone from Bidlake and Payne (2001). The groundwater system received an average (from 1980 to 2010) of about 523,680 acre-ft, or about $17 \mathrm{in}$. of recharge from precipitation a year (Welch and others, 2014). Recharge was applied to the highest active model layer.
Water use by humans also generates groundwater recharge from application of water at or near the land surface. On the Kitsap Peninsula, this includes septic systems and outdoor irrigation return flows. The consumptive use rate for indoor domestic use was set at 10 percent in non-sewered areas, and the consumptive use rate for outdoor use was set at 90 percent (Washington State Department of Ecology, 2009). Consumptive use is the amount of water that is lost from the system through means such as evapotranspiration. Groundwater pumpage totals (Welch and others, 2014) were apportioned between sewered and non-sewered parts of the water-service area, with only non-sewered areas having return flows. Return flows were applied to cells that were located in areas that had non-sewered full-time residential parcels based on county parcel information. In addition to groundwater, the city of Bremerton also uses surface water from the Union River for some of its drinking water supply, so that amount of water used in non-sewered areas was included in the septic system return-flow values. The return flows were simulated as an injection well with a specified flux located in the uppermost active model layer at the cell location (row-column) of each non-sewered full-time residential parcel.

A recharge multiplier was used in conjunction with the Recharge Package so that recharge was allowed to vary within plus or minus 5 percent during calibration.

\section{Groundwater Withdrawals}

The Well Package (WEL) of MODFLOW (McDonald and Harbaugh, 1988) was used to simulate groundwater withdrawals from pumping wells. The well package simulates a specified-flux boundary in each model cell to which a well is assigned based on the withdrawal rate for each well or group of pumping wells in the cell. Withdrawals (in cubic feet per day) (Welch and others, 2014) were specified for each stress period. If the specified pumping rates resulted in drawdowns to the base of the aquifer (model layer) in a particular model cell, then the pumping rate was automatically reduced to an amount that could be supplied by the aquifer.

Locations of public-supply wells were obtained from the Washington Department of Health. Locations of domestic wells were estimated by assuming that a well was located at each full-time residential parcel that was not connected to a public-water system. The vertical distribution of public-supply well, golf course, and fish hatchery withdrawals among model layers was based on the reported depth of the open interval of the well and the nearest aquifer unit in the hydrogeologic framework. The model layer assigned to each domestic well was initially determined by assigning it to the same aquifer unit as the nearest known hydrogeologic framework or public-supply system well. Well assignments then were reviewed and adjusted as needed based on known locations of wells in the deeper units. 


\section{Initial Hydraulic Properties}

The initial hydraulic properties of horizontal hydraulic conductivity $\left(\mathrm{K}_{\mathrm{h}}\right)$, anisotropy $\left(\mathrm{K}_{\mathrm{h}}: \mathrm{K}_{\mathrm{v}}\right)$, and specific storage were assigned on the basis of values tabulated from analysis of specific-capacity data (Welch and others, 2014) and previous studies (Frans and others, 2010; Johnson and others, 2011). A uniform distribution of hydraulic parameter values was initially specified in the numerical model for each hydrogeologic unit. These values are considered the initial hydraulic properties for calibrating the model.

\section{Horizontal Hydraulic Conductivity}

Initial values of horizontal hydraulic conductivity $\left(K_{h}\right)$ for the hydrogeologic units were based on analyses of specific-capacity data and results of aquifer tests (Welch and others, 2014). Because there is no evidence to suggest that hydraulic conductivity varies with direction (no preferential flow), horizontal isotropy $\left(K_{x}=K_{y}\right)$ was assumed. Initial values of horizontal hydraulic conductivity in aquifer units ranged from $200 \mathrm{ft} / \mathrm{d}$ in the Qvr aquifer to $9 \mathrm{ft} / \mathrm{d}$ in the QA2 aquifer. Initial values of horizontal hydraulic conductivity in confining units ranged from $3.5 \mathrm{ft} / \mathrm{d}$ in the Qvt confining unit to $1 \mathrm{ft} / \mathrm{d}$ in the QC1, QC2, QC3, and QC4 confining units. The initial horizontal hydraulic conductivity of the bedrock units were set to $0.1 \mathrm{ft} / \mathrm{d}$.

\section{Vertical Hydraulic Conductivity}

Initial values of vertical hydraulic conductivity $\left(K_{v}\right)$ were assigned to each hydrogeologic unit as the ratio of horizontal to vertical hydraulic conductivity (vertical anisotropy). Assignment of vertical anisotropy to hydrogeologic units was based on unit lithologic and hydraulic characteristics, and initial vertical anisotropy values used in a previous groundwater-flow model for a nearby area (Drost and others, 1999). The vertical hydraulic conductivity values were initially set relative to the horizontal hydraulic conductivity during calibration using the following anisotropy ratios:

- Aquifers composed of primarily well-sorted sand and gravel (hydrogeologic units Qvr, Qva, QC1pi, QA1, QA2, and QA3) were assigned a vertical anisotropy of 10 (that is, $\mathrm{K}_{\mathrm{v}}=\mathrm{K}_{\mathrm{h}} / 10$ );

- Confining units composed of primarily poorly sorted and fine-grained deposits (hydrogeologic units QC1, QC2, QC3, and QC4) were assigned a vertical anisotropy of 100. The confining unit Qvt was assigned a vertical anisotropy of 20 based on input from local geologists (Mike Krautkramer, Robinson and Noble, Inc., written commun., 2014).

- The shallower part (upper $200 \mathrm{ft}$ of unit thickness) of the bedrock unit was assigned a vertical anisotropy of 0.1 to account for an assumed greater flow along subvertical secondary permeability features (joints and fractures).

- The deeper part (greater than $200 \mathrm{ft}$ ) of the bedrock unit was considered to be isotropic to account for an assumed reduction or elimination of groundwater movement along secondary permeability features, and the reduction of primary porosity due to compressive forces.

\section{Storage Properties}

Specific storage values were assigned to model cells to represent the change in groundwater storage that results from changes in water levels in a confined aquifer. Unconfined and confined conditions occur within the groundwater system, so each unit was assigned a specific yield and a specific storage value. Values of specific storage in confined aquifers commonly range from $1.0 \times 10^{-5}$ to $1.0 \times 10^{-6} \mathrm{ft}^{-1}$ (Riley, 1998), and values for clay-bearing confining units could be an order of magnitude larger, based on reported compressibility values (Freeze and Cherry, 1979). An initial specific storage value of $1.0 \times 10^{-6} \mathrm{ft}^{-1}$ was assigned to all aquifer units. An initial specific storage value of $1.0 \times 10^{-5} \mathrm{ft}^{-1}$ was assigned to all confining units and the bedrock units. The initial specific yield value of 0.2 was assigned to all units.

\section{Model Calibration}

Model calibration is the adjustment of model parameters within reasonable limits so that the differences (residuals) between measured and simulated groundwater levels and stream baseflows are minimized with respect to an objective function. The calibration is assessed by examining how well the simulated quantities fit the measured quantities from previous investigations (Welch and others, 2014).

\section{Calibration Procedure}

The model was calibrated using a combination of traditional trial-and-error adjustment of parameters and the parameter estimation program (PEST; Doherty, 2005, 2006), enhanced with Pilot-Point Parameterization (Doherty, 2003; Doherty and others, 2010), Tikhonov Regularization (Doherty, 2003; Fienen and others, 2009), and Singular Value Decomposition (Doherty and Hunt, 2010). PEST automatically adjusted model parameters (horizontal and vertical hydraulic conductivity, specific storage for layers 2 through 14, specific yield for layers 1 through 3 and 13 through 14, recharge multiplier, and stream and general head boundary conductance) within specified limits through a series of model runs. After each model run, simulated groundwater levels and stream baseflows were compared to measured 
values. Model runs continued until the differences (residuals) between simulated and measured values were minimized.

Pilot-point parameterization was used to represent spatial heterogeneity in horizontal and vertical hydraulic conductivity and specific storage. Pilot points were evenly distributed over the entire model domain by hydrogeologic unit and were used as surrogate parameters at which values for horizontal and vertical hydraulic conductivity were estimated during calibration. Estimated values of horizontal and vertical hydraulic conductivity and storage coefficients at pilot points were interpolated throughout the active model domain using kriging (a geostatistical algorithm) procedures in PEST. The result is a smooth variation of the hydraulic property over the model domain. Numerous studies have used pilot points for groundwater model calibration (de Marsily and others, 1984; LaVenue and Pickens, 1992; Petkewich and Campbell, 2007) and have proven them to be powerful, flexible tools for representing spatial heterogeneity in various types of aquifer-hydraulic properties.

Pilot points generally were spread in a regular grid pattern where possible. The pilot points were distributed vertically so that each hydrogeologic unit contained pilot points. If a pilot point for any given hydrogeologic unit occupied a location where that unit was absent, it was deleted from that location for that unit to ensure that the pilot points for each hydrogeologic unit were kriged only to other points within that unit.

Where possible, hydraulic conductivity information from Frans and others (2011) was honored for Bainbridge Island because the smaller scale and localized calibration of that model generated a better fit for the observed data on Bainbridge Island than recalibrating that area using the more disparate pilot point distribution in the larger Kitsap Peninsula model.

\section{Calibration Data}

The groundwater-flow model was calibrated to water level and stream baseflow measurements. A total of 18,835 water-level measurements were used from 618 wells from January 2007-December 2012. Water levels, as depth below land surface, were converted to a water-level altitude (NAVD 88) based on the LiDAR-derived land-surface altitude at the location of the well. Wells used to measure water levels were located within a model cell at a location given by the measured latitude and longitude of the well. The reported depth of the well screen and the well log were used to determine the model layer that represented the hydrogeologic unit screened by the well.

Stream baseflow was measured at 43 locations (Welch and others, 2014). The USGS made six synoptic streamflow measurements during the summers of 2011 and 2012. The KPUD also made synoptic baseflow measurements and maintained various streamgages. Hydrograph separation was done on daily discharge from the streamgages to estimate the baseflow portion of the discharge measurement. The model was calibrated against baseflow measurements made between July and October.

\section{Observations Weighting}

Calibration using both measured groundwater levels and streamflows was done with observation weights adjusted to ensure equal contribution by the three groups (heads, differences in water levels for transient targets, and streamflows) to the model objective function, in accordance with the guidelines presented by Doherty and Hunt (2010). Observations and, therefore, residuals, are weighted to allow a meaningful comparison of measurements with different units (weighted residuals are dimensionless) and to reduce the influence of measurements with large errors or uncertainty. Model calibrations using observations of different types require a weighting scheme that adequately represents the contribution to total model error of observations made in different measurement units. A weighting scheme was designed to balance the contribution of the numerically larger mean baseflow measurements over water-level measurements (different measurement units: cubic feet per day for baseflow rather than feet for the water-level measurements) To redress this imbalance, weights for each class of observations were proportionally scaled such that waterlevel observations and baseflow observations each made roughly equivalent contributions to total model error. All water-level observations were assigned equal relative weights and baseflow observations were assigned equal relative weights. For the final parameter values, the contributions to the sum of squared weighted residuals of each of the observation groups were flow observations ( 30 percent), head ( 30 percent), and head differences (40 percent.)

\section{Final Parameter Values and Sensitivities}

The ability to estimate a parameter value during the calibration process is related to the model-simulated output's sensitivity to changes in the parameter value. For example, if a parameter has a high sensitivity, the observation data effectively estimate the value. For parameters with low sensitivity changes in the value have little effect on the model-calibration process. Insensitive parameters may or may not be close to their corresponding field values and are not likely to be estimated accurately during the parameter-estimation process.

Relative composite sensitivities are a measure of composite changes in model outputs that are caused by small changes in the value of a modeled parameter (Doherty, 2005). For a given modeled parameter, the larger that the value of the associated relative composite sensitivity is, the more sensitive the model is to that parameter. Relative composite sensitivities were calculated and analyzed for 1,418 parameters used in the model-calibration process (table 3). Median sensitivities are presented for each hydrogeologic unit for the horizontal and vertical hydraulic conductivities, the storage coefficients, and other parameters. 


\section{Numerical Simulation of the Groundwater-Flow System of the Kitsap Peninsula, West-Central Washington}

Table 3. Parameter sensitivities and final values for calibration parameters, Kitsap Peninsula, west-central Washington.

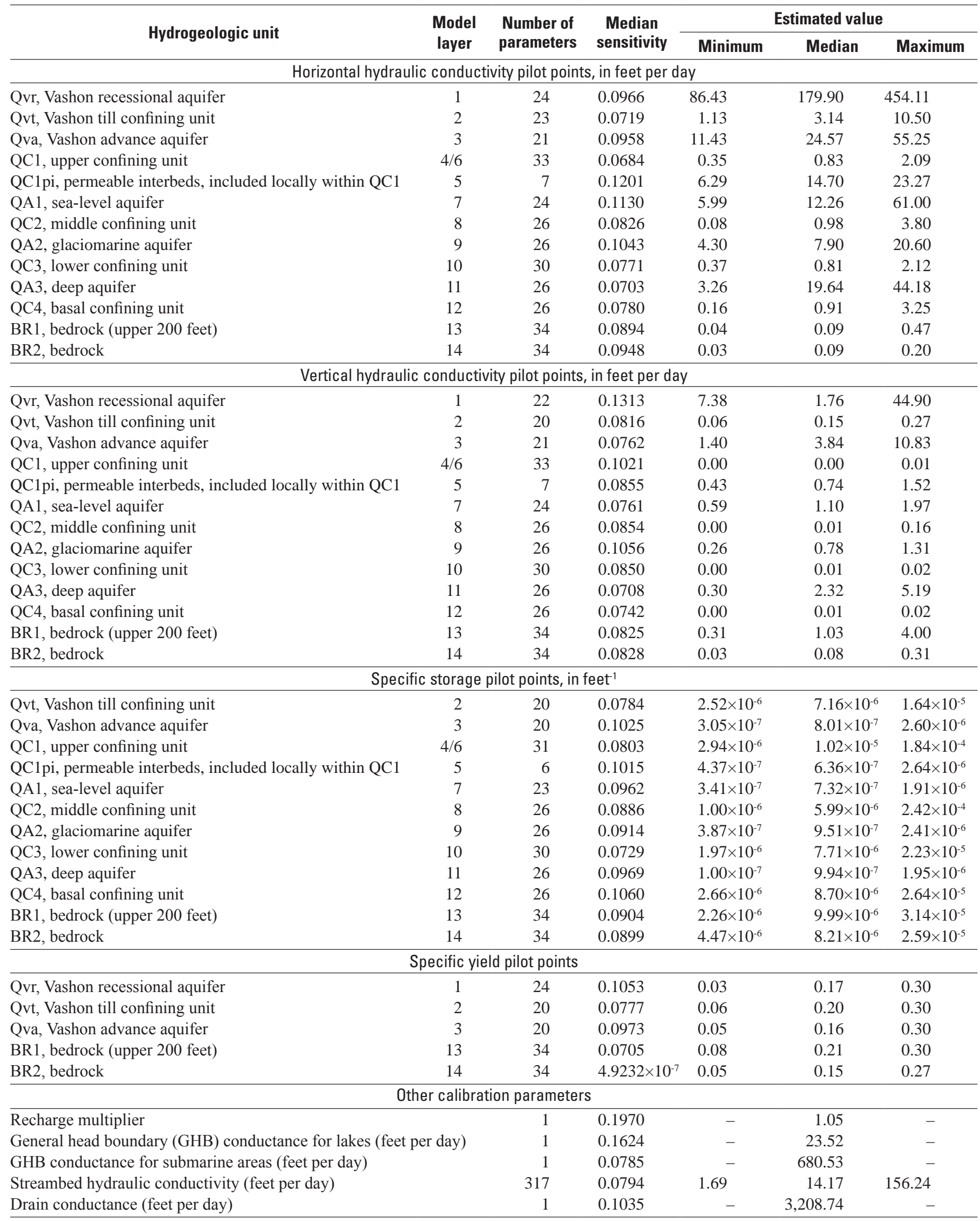


Overall, the model is most sensitive to the recharge multiplier, as expected, because the amount of recharge principally controls the inflow to the groundwater-flow system. For the horizontal hydraulic-conductivity pilot points, the aquifers were more sensitive than the confining units. For the vertical hydraulic-conductivity pilot points, the confining units were generally more sensitive than the aquifers, except for the Qvr aquifer unit (model layer 1). The hydraulic conductivity of the Qvr layer likely is more sensitive because many of the streamflow sites are in this layer. These results were as expected, with the aquifers being most sensitive to changes in horizontal hydraulic conductivity, and the confining units being most sensitive to the vertical hydraulic conductivity.

The final parameter values for the 1,097 pilot points are shown in table 3 . The highest median value for estimated horizontal hydraulic conductivity was in the Qvr aquifer $(179.9 \mathrm{ft} / \mathrm{d})$, followed by the Qva aquifer $(24.57 \mathrm{ft} / \mathrm{d})$. Of the aquifers, the QA2 aquifer had the lowest median value for the estimated horizontal hydraulic conductivity at $7.90 \mathrm{ft} / \mathrm{d}$. These values were within the range of values estimated using specific-capacity data (Welch and others, 2014). The median vertical hydraulic conductivities for the aquifers generally were an order of magnitude smaller than the horizontal hydraulic conductivities and ranged from $0.74 \mathrm{ft} / \mathrm{d}$ for the QC1pi aquifer to $16.76 \mathrm{ft} / \mathrm{d}$ for the Qvr aquifer.

\section{Assessment of Model Fit}

A graphical and descriptive comparison of simulated and measured groundwater levels and streamflow values provides a clear insight to the model fit and complements the statistical measures of model fit. Such a comparison indicates how well the model replicates the flow system. It is important to determine that the model accurately simulates the regional direction and amounts of flow in the groundwater-flow system.

\section{Comparison of Measured and Simulated Hydraulic Heads and Baseflows}

The results of the calibration were assessed by comparing measured and simulated quantities (groundwater levels and stream baseflows) and by examining the mean and standard deviation of residuals (unweighted) and the root mean-square error (RMSE) of residuals for groundwater levels and baseflow measurements. The mean of residuals represents the average difference between all measured and simulated values (residuals), and the sign of the mean of residuals (bias) indicates whether the model is over- or under-predicting values (negative and positive mean of residuals, respectively). The standard deviation of residuals is a measure of how much variation there is in residual values greater than and less than the mean residual value. A low standard deviation indicates that the residuals tend to be close to the mean, whereas high standard deviation indicates that residuals are spread out over a large range of values around the mean. The RMSE of weighted residuals provides a measure of variation that considers measurement accuracy. The RMSE of the difference between simulated and measured hydraulic heads in the observation wells, divided by the total range in water levels in the groundwater system (Anderson and Woessner, 1992, p. 241), also should be less than 10 percent to be acceptable (Drost and others, 1999).

The calibration statistics for groundwater levels (by hydrogeologic unit) and stream baseflow are shown in table 4. Calibration statistics were used to evaluate how well the model simulates measured values (fit). The best fit for simulated and measured groundwater-level values based on the RMSE occurred in aquifers Qvr and QA2; the worst fit occurred in aquifer QC1pi. Aquifers QA1, QA2, and Qvr had the lowest value of mean residuals, indicating simulated groundwater levels in these units had the lowest model bias.

Table 4. Calibration statistics for numerical flow model of the Kitsap Peninsula, west-central Washington.

[Hydrogeologic unit: Qvr, Vashon recessional aquifer; Qva, Vashon advance aquifer; QC1pi, permeable interbeds; QA1, sea-level aquifer; QA2, glaciomarine aquifer; QA3, deep aquifer]

\begin{tabular}{|c|c|c|c|c|c|c|c|c|}
\hline \multirow{2}{*}{ Calibration statistic } & \multicolumn{6}{|c|}{ Hydrogeologic unit } & \multirow{2}{*}{$\begin{array}{c}\text { All head } \\
\text { measurements } \\
\text { (feet) }\end{array}$} & \multirow{2}{*}{$\begin{array}{c}\text { All flux } \\
\text { measurements } \\
\text { (cubic feet } \\
\text { per day) }\end{array}$} \\
\hline & Qvr & Qva & QC1pi & QA1 & QA2 & QA3 & & \\
\hline Number of observations & 70 & 5,292 & 677 & 8,916 & 2,348 & 1,290 & 18,834 & 321 \\
\hline Mean residual, in feet or cubic feet per day & -12.35 & 16.24 & 53.48 & -0.69 & -7.46 & -26.23 & 3.70 & $8,700.92$ \\
\hline $\begin{array}{l}\text { Standard deviation of residuals, in feet or } \\
\text { cubic feet per day }\end{array}$ & 16.55 & 54.41 & 64.00 & 41.60 & 30.84 & 19.42 & 47.01 & $212,445.73$ \\
\hline Root mean-square error & 20.65 & 56.78 & 83.40 & 41.61 & 31.73 & 32.64 & 47.16 & $214,125.69$ \\
\hline
\end{tabular}


The final calibration has a RMSE for all water levels and stream baseflows of $47.16 \mathrm{ft}$ and $214,125.69 \mathrm{ft}^{3} / \mathrm{d}$, respectively. Given that the total range of average measured groundwater levels is $647.4 \mathrm{ft}$, the RMSE of $47.16 \mathrm{ft}$ is about 7 percent of the total range. Similarly, the range of average stream baseflow- measurements is $3,442,455 \mathrm{ft}^{3} / \mathrm{d}$, and the RMSE of $214,125.69 \mathrm{ft}^{3} / \mathrm{d}$ is about 6 percent of the total range. Overall, the groundwater levels and baseflow measurements have a RMSE divided by the total range of values of less than 10 percent indicating a good model fit (Drost and others, 1999).

A plot of measured and simulated groundwater-level altitudes provides a useful graphical assessment of model calibration (fig. 5). Measured and simulated values should plot close to a line with a slope of 1.0 and an intercept of zero. This diagonal line represents perfect agreement between measured and simulated values (the line of equal measured and simulated values), and the magnitude of the residual (difference between measured and simulated values) is reflected in the distance of the value above or below the line. Positive residuals (measured value is greater than simulated) and negative residuals (measured value is less than simulated) plot below and above the line, respectively. Measured and simulated values shown in figure 5 generally are along the line of equal measured and simulated values; groundwater-level altitudes in the range of 200-400 ft tend to be underpredicted.

The results of the calibration also were evaluated by displaying the simulated water levels (heads) in each aquifer unit (figs. 6A-E). The residuals (measured target value minus model-simulated value in that well) for each of the monthly and synoptic wells screened in the hydrogeologic unit are posted at well locations. Simulated water-level altitudes (figs. 6A-E) indicate that the model reasonably simulated the groundwater conditions observed by Welch and others (2014). The spatial distribution of the hydraulic-head residuals does not indicate any major patterns of bias except for the QC1pi unit where the model tends to under -predict the hydraulic heads and the QA3 unit where the model tends to over-predict the hydraulic heads.

Simulated water-level altitudes in the Qva aquifer (fig. 6A) indicate flow moving from the interiors of the Kitsap Peninsula and Bainbridge Island toward Puget Sound and toward major stream channels. For the Qva aquifer, the mean residual was $16.24 \mathrm{ft}$ (table 4), so the model tended to underpredict the hydraulic heads overall for this aquifer. Simulated heads mostly are between $\pm 60 \mathrm{ft}$ of measured values. The model accurately estimated the same general flow pattern as was mapped by Welch and others (2014).

Simulated water-level altitudes in the QA1 aquifer (fig. 6C) indicate flow moving from the interiors of the Peninsula and Bainbridge Island towards Puget Sound. For the QA1 aquifer, the mean residual was $-0.69 \mathrm{ft}$ (table 4), so the model tends to slightly over -predict the hydraulic heads. Simulated heads mostly are between $\pm 60 \mathrm{ft}$ of measured values. The model accurately estimated the same general flow pattern as was mapped by Welch and others (2014).

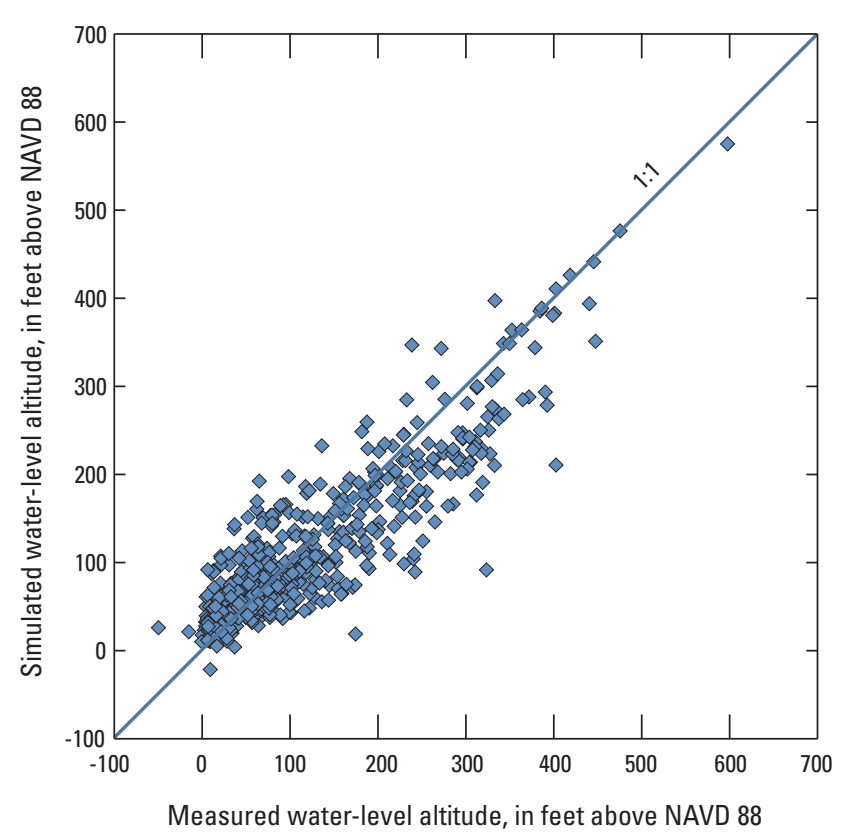

Figure 5. Simulated and measured water-level altitudes in the groundwater-flow model of the Kitsap Peninsula, west-central Washington. NAVD 88, North American Vertical Datum of 1988.

Simulated water-level altitudes in the QA2 aquifer (fig. 6D) indicate flow moving from the interiors of the Kitsap Peninsula and Bainbridge Island toward Puget Sound. For the QA2 aquifer, the mean residual was $-7.46 \mathrm{ft}$ (table 4), so the model tended to slightly over-predict the hydraulic heads. Although the overall flow patterns were not distinguishable based on the observation-well data alone (Welch and others, 2014), the model accurately estimated the same general flow pattern as the one mapped by Welch and others (2014) for those areas where sufficient measurements were present to make a determination of flow direction.

The mean residual for the QA3 aquifer was $-26.23 \mathrm{ft}$, so the model tended to overpredict the hydraulic heads in this unit. As with the QA2 aquifer, general flow patterns for the Kitsap Peninsula as a whole were not distinguishable based on the observation-well data (Welch and others, 2014); however, the model indicated that flow occurs radially off the center of the Kitsap Peninsula and that water flows from the Kitsap Peninsula beneath Bainbridge Island and then discharges to Puget Sound in the east (fig 6E). This flow pattern is consistent with the limited amount of observation data that is available (Welch and others, 2014).

The results of the calibration also were evaluated by comparing measured and simulated groundwater-level hydrographs. One hydrograph from a well in each major aquifer is shown in figure 7. Measured water levels generally fluctuate in response to seasonal changes in recharge. Simulated water levels also fluctuate in response to seasonal variation in recharge and, in many but not all cases, the magnitude and timing of these fluctuations are similar to the changes in measured water levels. 


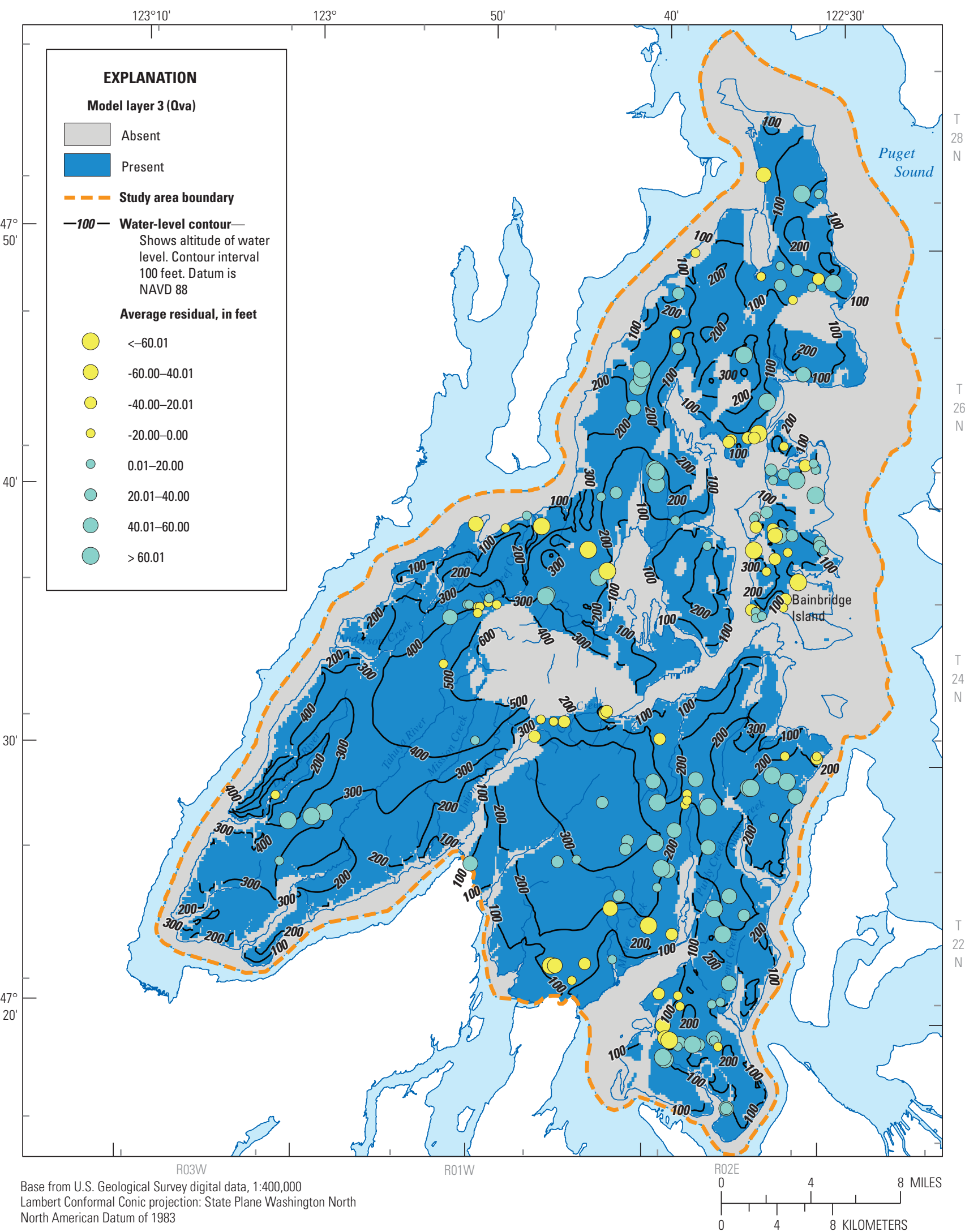

A. Model layer 3-Vashon advance aquifer (Qva).

Figure 6. Simulated water-level altitudes and location and simulated average magnitude of hydraulic-head residuals, Kitsap Peninsula, west-central Washington. 


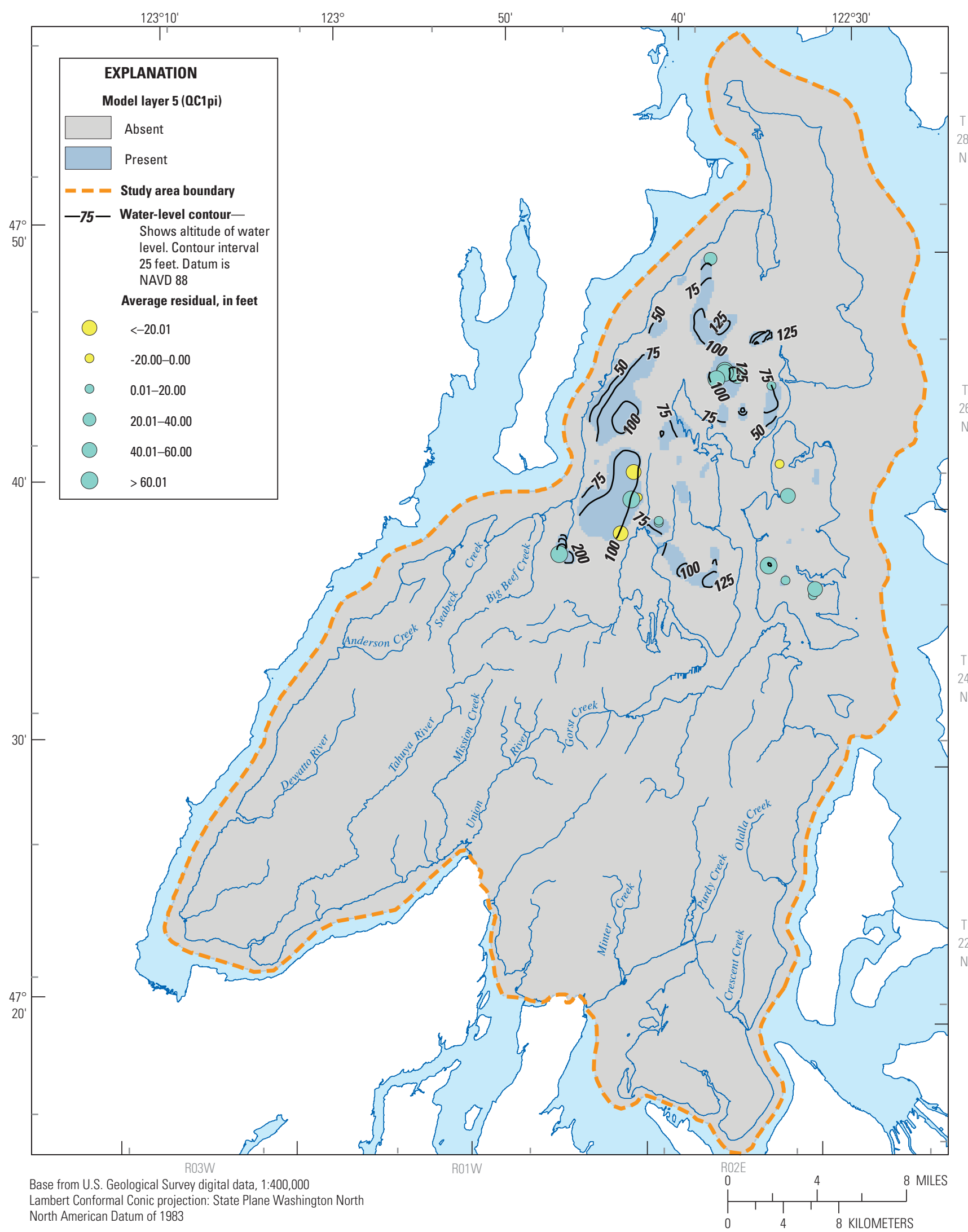

B. Model layer 5-permeable interbeds (QC1pi).

Figure 6. - Continued 


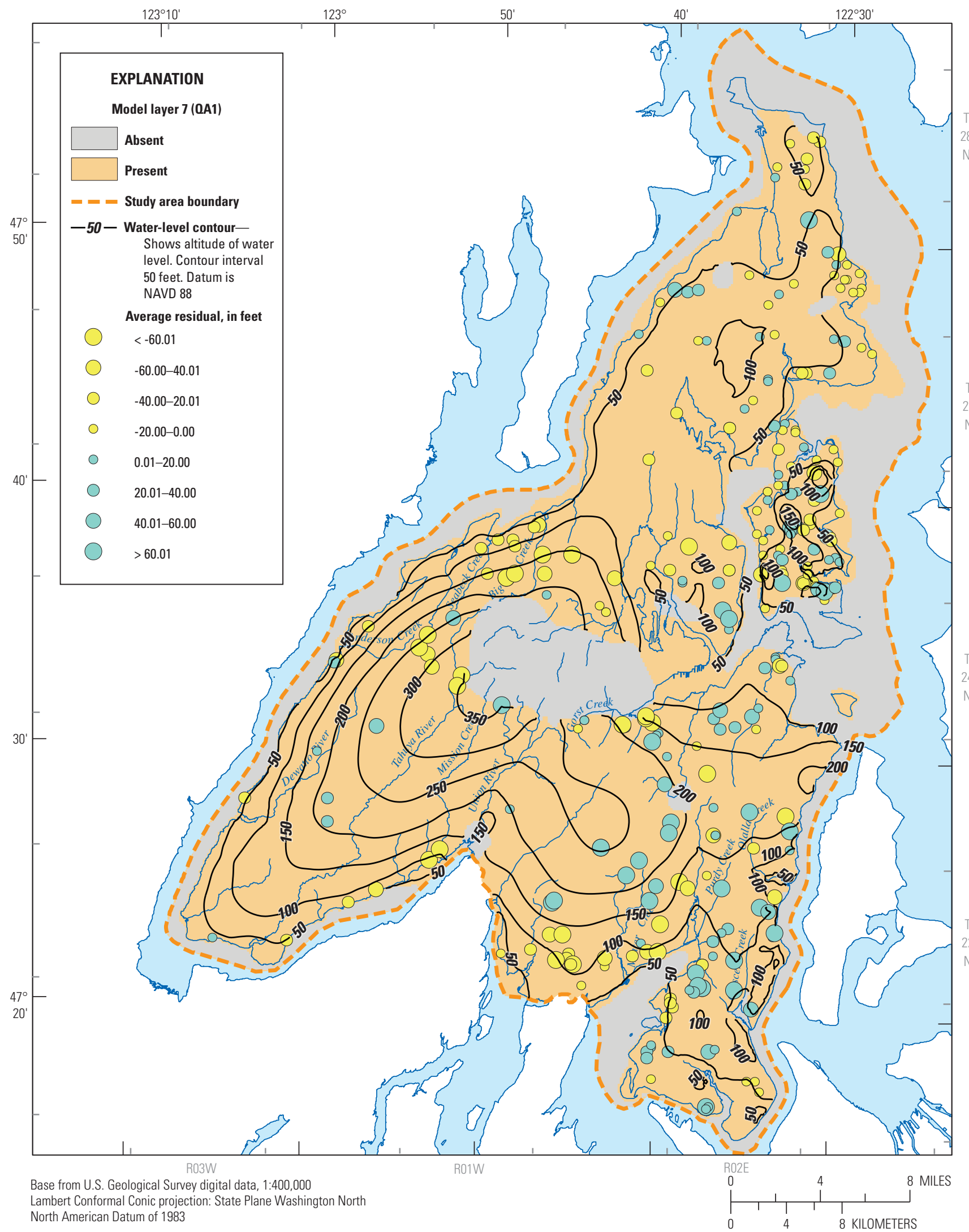

C. Model layer 7—sea level aquifer (QA1).

Figure 6. - Continued 


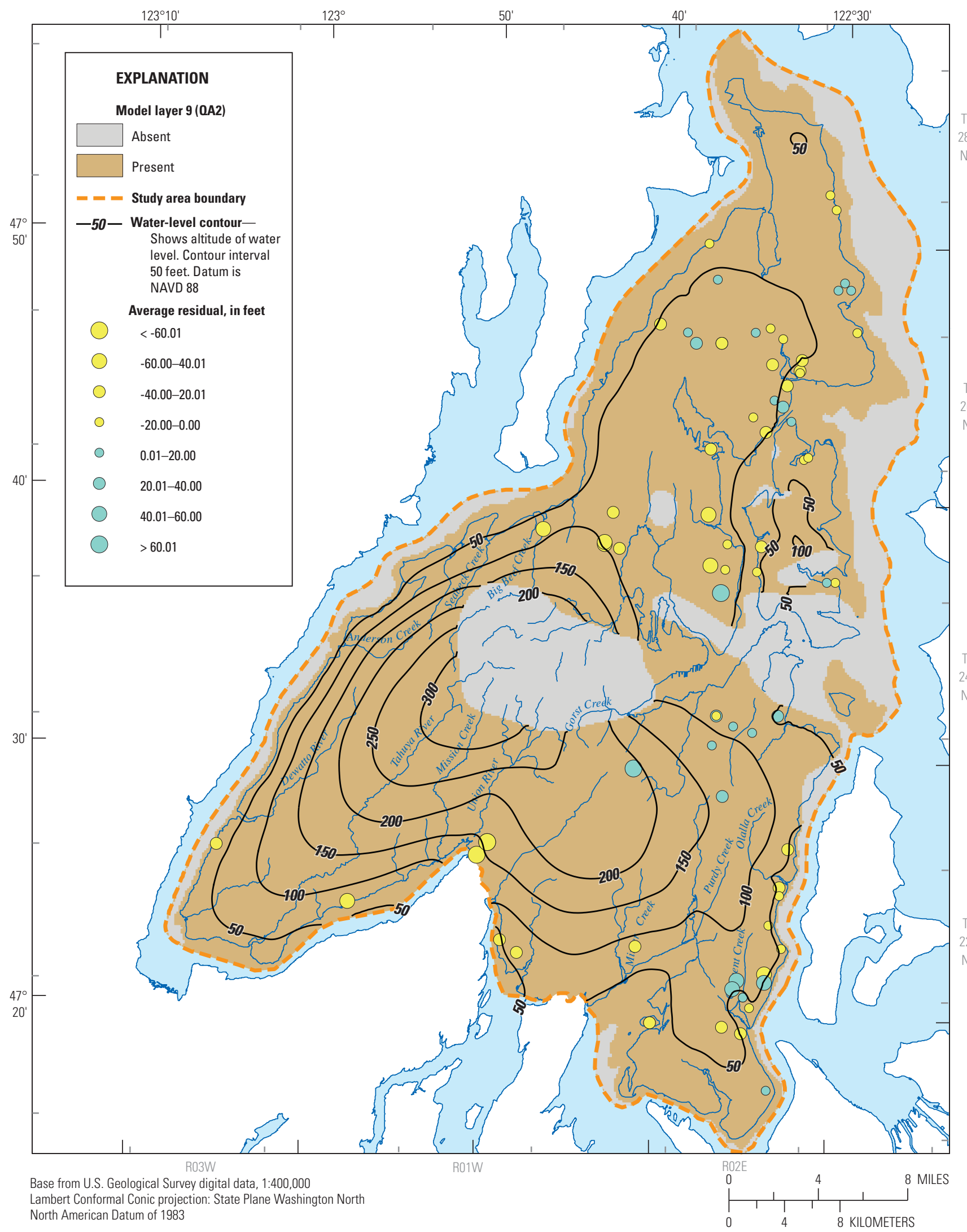

D. Model layer 9-glaciomarine aquifer (OA2).

Figure 6.-Continued 


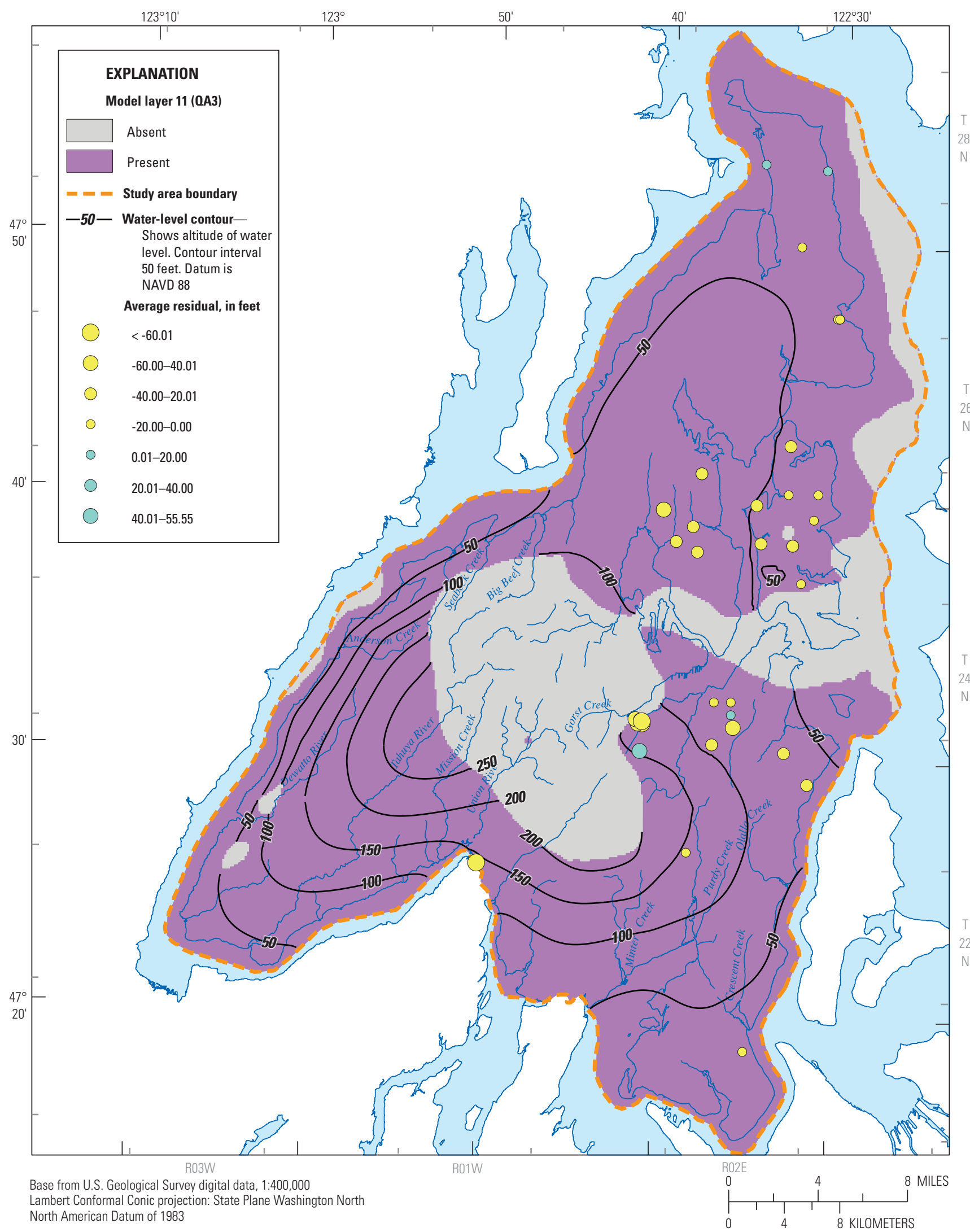

E. Model layer 11—deep aquifer (QA3).

Figure 6.-Continued 

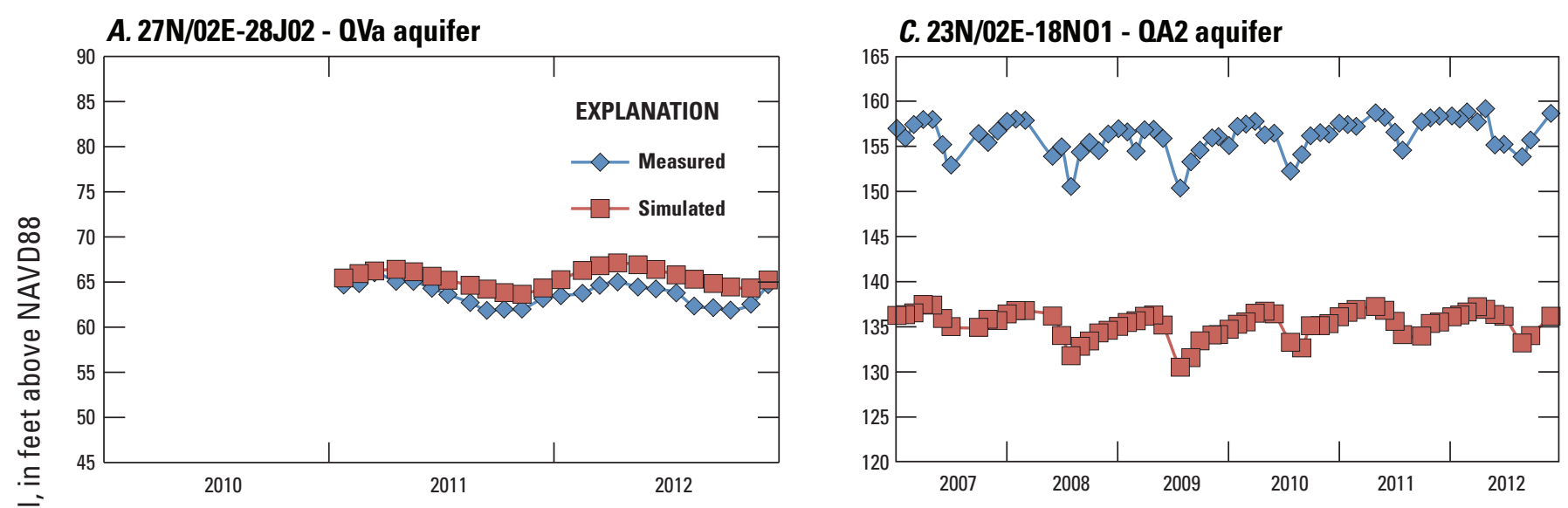

\section{B. 22N/03W-20001 - QA1 aquifer}
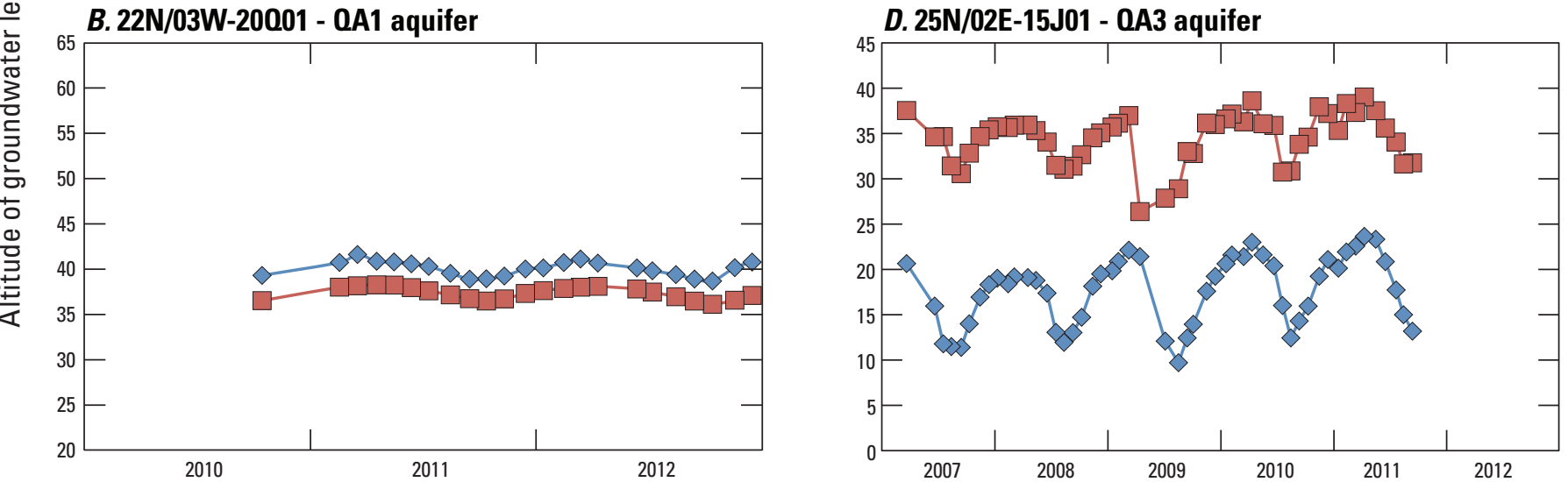

Figure 7. Simulated and measured groundwater-level altitudes for selected wells, Kitsap Peninsula, west-central Washington.

A comparison of the measured and simulated groundwater discharge to streams (baseflow) in the model area was based on stream baseflow measurements made during the summer months of July-October. Baseflow measurements from 43 measurement sites (Welch and others, 2014) were compared to simulated groundwater discharge to streams at the same locations (fig. 8). Baseflow was reasonably well simulated by the calibration, as indicated by the line of equal measured and simulated values. Positive residuals (measured value is greater than simulated) and negative residuals (measured value is less than simulated) plot below and above the line, respectively.

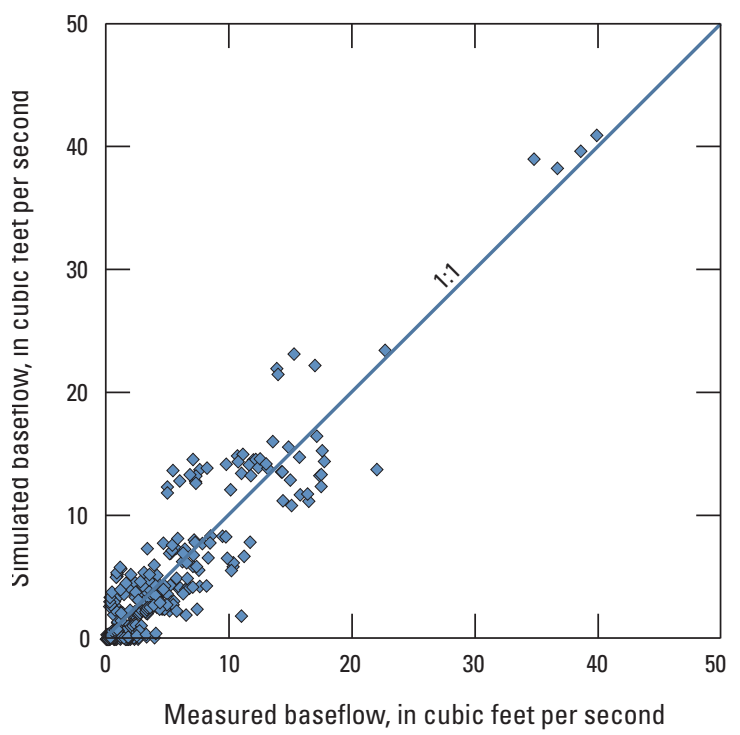

Figure 8. Simulated and measured water-level baseflows in the groundwater-flow model of the Kitsap Peninsula, west-central Washington. 


\section{Model Limitations}

A groundwater-flow model represents a complex, natural system with a set of mathematical equations that describe the groundwater-flow system. Intrinsic to the model is the error and uncertainty associated with the approximations, assumptions, and simplifications that must be made. Hydrologic-modeling errors typically are the consequence of a combination of (1) input data, (2) representation of the physical processes by the algorithms of the model, and (3) parameter estimation during the calibration procedure (Troutman, 1985). Examples of the three types of model errors and how those errors limit application of the model are listed below:

1. Input data on types and thicknesses of hydrogeologic units, water levels, and hydraulic properties represent only approximations of actual values. Parts of the model domain include areas that are poorly characterized. In areas without lithologic well logs, variability in hydrogeologic properties or depths of contacts may be outside the range of values in areas that have been better characterized, and the errors associated with this variability would remain unrepresented. Specific conclusions drawn from regions of the model with sparse observations should be limited to general flow directions and relative magnitudes. The calibration bounds for hydraulic-property data generally came from specific-capacity tests, which typically measure drawdown at one time and at one pumping rate, and typically are not as accurate as aquifer tests. Thus, broad ranges of hydraulic-property parameter values are possible. Lack of information on streambed hydraulic conductivity values resulted in these values being poorly constrained, which may limit the accuracy of groundwater/surface-water exchanges.

2. All the physical processes within a watershed cannot be represented completely or “captured” in a numerical model. Determining if a weakness in a simulation is attributable to input data error or model shortcomings is almost impossible, but the simplifying assumptions and generalizations that are incorporated into a model undoubtedly affect the results of the simulation. Model-discretization errors (including effects of averaging elevation information over the model cell size) result from inaccuracies in the geometric representation of hydrogeologic units, in the representation of the bedrock areas and their contact with unconsolidated units, and in the location of the fault zone. For this reason, interpretations of simulation results should be limited to scales several times greater than the model spatial and temporal resolutions of $500 \mathrm{ft}$ and 1 month.

3. Errors in parameter estimates occur when improper values are selected during the calibration process. Various combinations of parameter values can result in low residual error, yet improperly represent the actual system. An acceptable degree of agreement between simulated and measured values does not guarantee that the estimated model-parameter values uniquely and reasonably represent the actual parameter values. The use of automatic parameter estimation techniques and associated statistics, such as composite scaled sensitivities and correlation coefficients, removes some of the effects of non-uniqueness, but certainly does not eliminate the problem entirely. The comparison of calibrated values to literature values also can reduce error caused by parameter estimation if the model simulation results are within previously accepted ranges. Limitations of the observation weighting scheme used in this study include non-varying weights for heads and streamflow that did not take into account measurement errors within each group of measurements.

If the regional groundwater-flow model is used appropriately, the effects of the simplifications and other potential errors can be limited. If the model is used for simulations beyond which it was designed, however, the generalizations and assumptions used could significantly affect the results. Because of the model scale and level of detail, the model generally is most applicable to analysis of regional-scale groundwater problems. Local scale heterogeneity in hydrologic properties, recharge, and discharge are not represented adequately by the regional-scale, groundwater-flow model constructed for this study. 


\section{Model Applications}

The calibrated model is an appropriate tool to estimate components of the groundwater budget for Kitsap Peninsula and the response of the groundwater system to changes in future pumpage and recharge conditions. Water-resource managers can use the model to inform decisions about future groundwater management. The uncertainties associated with the model discussed in section, "Model Limitations" are carried forward to these model applications.

\section{Model-Derived Groundwater Budget}

An approximate groundwater budget for 2012 for the study area is expressed in equation 1 :

$$
R+S_{\text {in }}=D+S_{\text {out }}
$$

where

$$
\begin{array}{ll}
R & \text { is recharge, } \\
S_{\text {in }} & \text { is groundwater coming in from storage, } \\
D & \text { is discharge, and } \\
S_{\text {out }} & \text { is groundwater going out to storage. }
\end{array}
$$

Recharge to the groundwater system primarily occurs as recharge from precipitation and seepage from lakes and streams and secondarily as seepage from septic systems. Discharge from the system occurs as seepage to streams, lakes, springs, and seepage faces; as evaporation from soils and transpiration by plants; as submarine seepage to Puget Sound; and as withdrawals from wells. A more detailed representation of the groundwater budget of the study area is

$$
\begin{gathered}
R_{p p t}+R_{\text {sec }}+R_{\text {sw }}+R_{\text {lake }}+S_{\text {in }} \\
=D_{\text {sw }}+D_{\text {sub }}+D_{e t}+D_{\text {ppg }}+D_{\text {springs }}+S_{\text {out }}
\end{gathered}
$$

where

$\begin{array}{cl}R_{\text {ppt }} & \text { is recharge from precipitation, } \\ R_{\text {sec }} & \text { is recharge from septic system returns, } \\ R_{s w} & \text { is recharge from streams, } \\ R_{\text {lake }} & \text { is recharge from lakes and Puget Sound, } \\ S_{\text {in }} & \text { is amount coming in from storage, } \\ D_{\text {sw }} & \text { is discharge to streams, } \\ D_{\text {sub }} & \text { is discharge to Puget Sound and lakes } \\ D_{\text {et }} & \text { is discharge by evapotranspiration, } \\ D_{\text {ppg }}^{\text {ing }} & \text { is pumpage from wells, } \\ D_{\text {springs }} & \text { is discharge to springs and seeps, and } \\ S_{\text {out }} & \text { is amount going out to storage. }\end{array}$

Table 5. Water budget for 2005-12 conditions, Kitsap Peninsula, west-central Washington.

\begin{tabular}{|c|c|c|c|}
\hline In & Rate & Out & Rate \\
\hline $\mathrm{R}_{\mathrm{pot}}$ & 563,130 & $D_{s w}$ & 303,032 \\
\hline $\mathrm{R}_{\mathrm{sw}}^{\mathrm{ppl}}$ & 41,395 & $D_{\text {sub }}^{\text {sw }}$ & 220,905 \\
\hline $\mathrm{R}_{\mathrm{sec}}^{\mathrm{sw}}$ & 22,193 & $D_{\text {pog }}^{\text {suo }}$ & 30,761 \\
\hline $\mathrm{R}_{\text {lakes }}^{\mathrm{sec}}$ & 2,509 & $\mathrm{D}_{\text {springs }}^{\text {ppg }}$ & 70,658 \\
\hline $\mathrm{S}_{\text {in }}^{\text {Ines }}$ & 231,060 & $\mathrm{~S}_{\text {out }}^{\text {Spings }}$ & 235,091 \\
\hline Total & 860,288 & & 860,448 \\
\hline
\end{tabular}

[Rate values are in acre-feet per year; may not sum due to rounding. $R_{\text {pot' }}$ recharge from precipitation; $R_{s w^{\circ}}$ recharge from streams; $R_{s e c}$, recharge from septic system returns; $R_{\text {lakes, }}$, recharge from lakes and Puget Sound; $S_{i n,}$, amount taken in from storage; $D_{\text {sw }}$ discharge to streams; $D_{\text {sub }}$, discharge to Puget Sound and lakes; $D_{\text {ppg }}$ pumping from wells; $D_{\text {springs }}$, discharge to springs and seeps; $\mathrm{S}_{\text {out }}$ amount going out to storage]

All of the water-budget components can be quantified based on the calibrated model except discharge by evapotranspiration. Evapotranspiration from the groundwater $\left(D_{\mathrm{e}}\right)$ is not known, but is assumed to be relatively insignificant to the total budget (assume $D_{e t}=0$ ) and therefore was not represented explicitly in the model.

The calibrated-model groundwater budget can be used to make some general observations of the groundwater system. For example, for 2005-2012, total flow through the groundwater system of the study area averaged more than 860,000 acre-ft/yr (table 5) including movement of water into and out of storage. The primary form of groundwater recharge was from precipitation. Recharge from septic systems accounted for a small amount of recharge (less than 4 percent), but this number may increase as residential development continues. Primary forms of groundwater discharge were to streams (303,032 acre-ft/yr), springs and seepage faces $(70,658 \mathrm{acre}-\mathrm{ft} / \mathrm{yr})$ and as groundwater outflow to marine waters and lakes $(220,905 \mathrm{acre}-\mathrm{ft} / \mathrm{yr})$ for a total of $594,595 \mathrm{acre}-\mathrm{ft} / \mathrm{yr}$. Total groundwater withdrawals averaged about 5 percent $(30,761 \mathrm{acre}-\mathrm{ft} / \mathrm{yr})$ of the total flow excluding changes in storage.

The groundwater budget indicates that the system was not at a steady-state condition during 2005-2012, based on the difference between the Sin and Sout values. The net amount being added to storage is 4,031 acre-ft/yr. However, the amount moving into and out of storage in the groundwater system shows significant variation from year to year. Simulated annual water budgets for 2005-2012 show the variations between the range of climatic conditions, including 


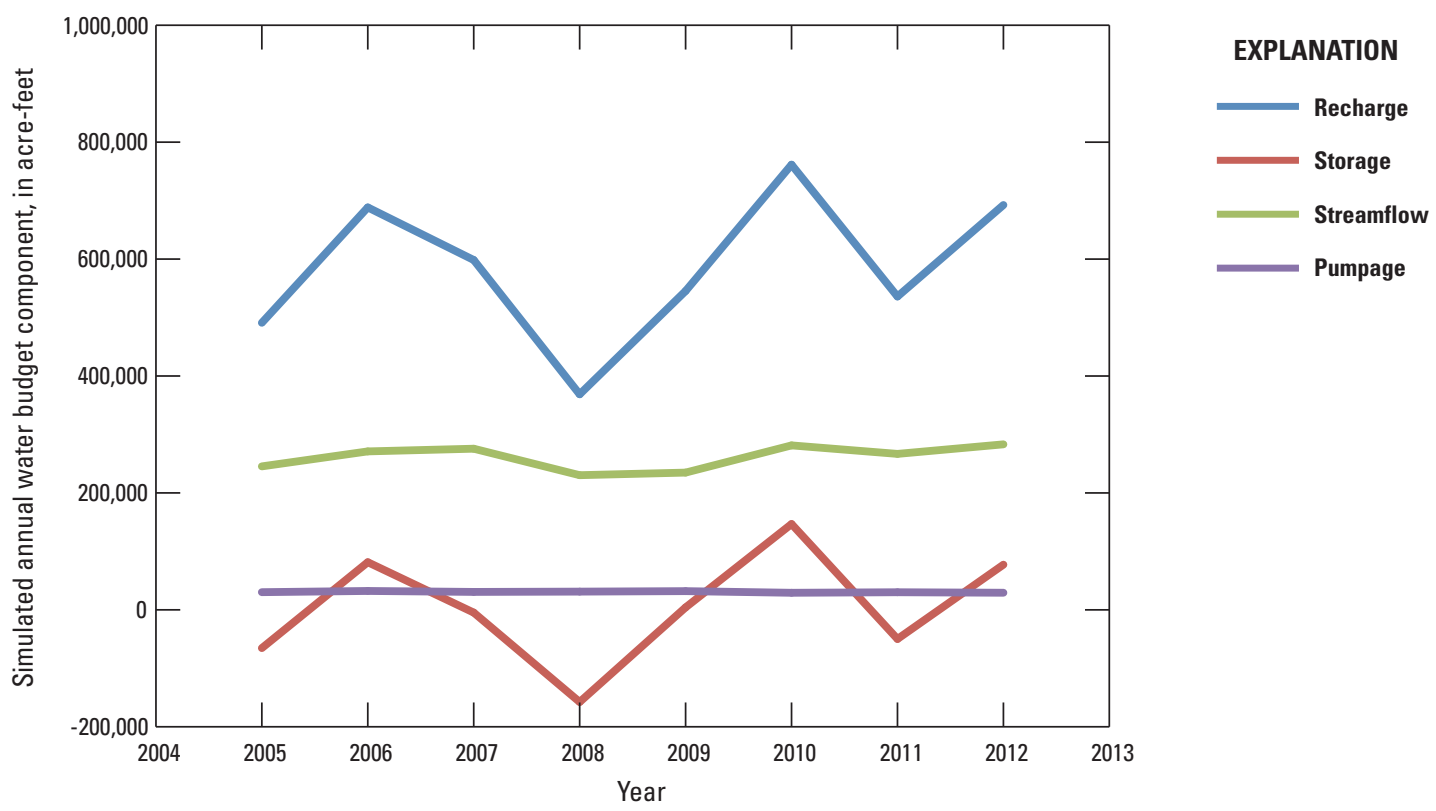

Figure 9. Simulated annual water budgets, Kitsap Peninsula, westcentral Washington, 2005-12.

an extremely dry year (2008) and wet years (2006, 2010, and 2012) (fig. 9). During above average precipitation years, recharge increases, baseflow in streams increases and more water is added to the groundwater system, which is indicated by positive storage numbers. In dry years, recharge decreases, baseflow in streams decreases, and water is withdrawn from storage, which is indicated by negative storage numbers. Groundwater pumping remained nearly constant.

Water budgets also were computed for the individual aquifer units for 2012 (fig. 10). All of the aquifers added water to storage during 2012, with the largest increase occurring in the Qva aquifer. The total amount added to storage for the five aquifers in 2012 was slightly more than 50,600 acre-ft/yr, as opposed to 77,319 acre-ft/yr for all of the units in the study area. This indicates that during 2012 most of the water went into storage in the aquifers with lesser amounts going to the confining units. The largest amount of groundwater pumping occurs from the QA1 aquifer, followed by the QA2 and Qva aquifers, respectively. Of the primary production aquifers, the QA3 had the least amount of groundwater withdrawals. The QC1pi aquifer has only a minor amount of groundwater pumping because it is not as widespread as the other aquifers.
The quantity of water that discharges naturally is not necessarily available for further groundwater development. Withdrawals superimposed on a previously stable system must be balanced by an increase in recharge, a decrease in discharge, a loss of storage within the aquifer, or a combination of these factors (Theis, 1940; Bredehoeft and others, 1982). Additional withdrawals, therefore, would result in a loss of storage (with an attendant decline in water levels) and a decrease in natural discharge. The effects of additional groundwater withdrawals are somewhat mitigated by septic-system returns. Furthermore, an important factor regarding septic-system returns or secondary recharge is a probable decrease in groundwater quality associated with increasing volumes of secondary recharge. Not all natural discharge in the model area is to Puget Sound; a large quantity of groundwater discharges to streams, lakes, springs, and seepage faces. The magnitude of potential groundwater development, therefore, depends on the hydrologic effects on discharge that can be tolerated. Because the initial effect of pumping is to remove water from storage, the effect of capture of groundwater discharge might not be apparent for many months or even many years after the onset of pumping. 
Simulated water bugets for individual aquifers (Units are acre-feet per year)
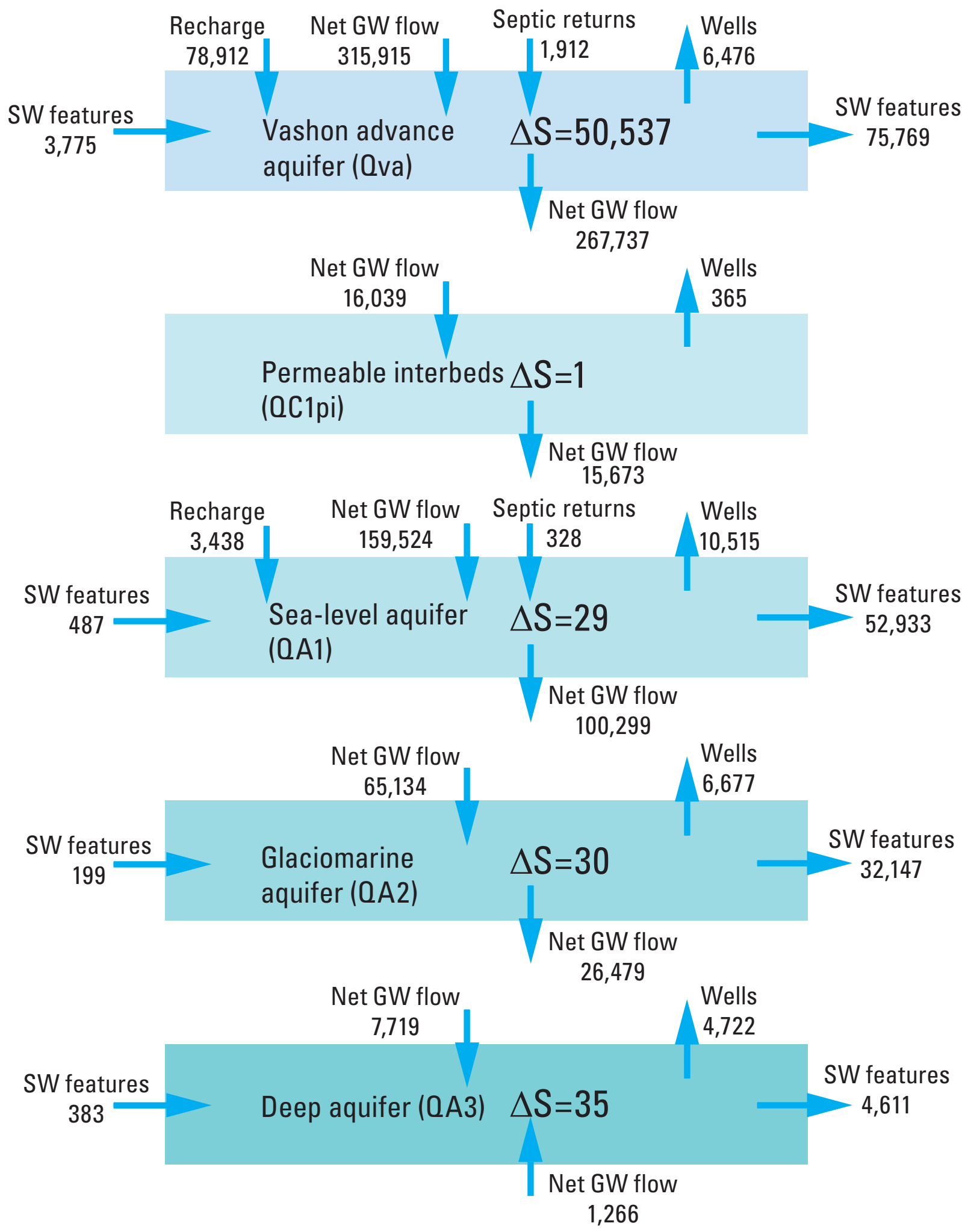

Figure 10. Simulated water budgets for individual aquifers, Kitsap Peninsula, west-central Washington, 2012. GW, groundwater; SW, surface water. 


\section{Model Scenarios}

The groundwater-flow model was used to simulate possible effects on water levels and groundwater discharge caused by potential changes in well withdrawals and recharge. Six scenarios were formulated and simulated using the calibrated model to demonstrate how the model could be used to investigate water-resource issues. Model results were compared to "base simulation" results that represent conditions for 2005-2012 prior to modification for simulations. Resultant changes in water-budget components (such as streamflows) were evaluated as well as changes to water-level altitudes. Results are shown for the Qva, QA1, and QA3 aquifers. Model simulations were made to evaluate the following conditions:

Simulation 1. A steady-state simulation using an average of 2005-2012 pumping rates and the 30-year annual average recharge.

Simulation 2. Remove all pumping and return flows throughout the model area to assess the effects the current amount of pumping has had on streamflows and water levels while maintaining all other "base simulation" conditions.

Simulation 3. Increase current withdrawals in all wells by 15 percent (with corresponding increases in return flows) for 2005-2012 while maintaining all other "base simulation” conditions.

Simulation 4. Decrease current outdoor water use by 80 percent for 2005-2012 to simulate effects of conservation efforts while maintaining all other "base simulation” conditions.

Simulation 5. Decrease recharge from precipitation by 15 percent throughout the model area for 2005-2012 to simulate drier conditions while maintaining all other "base simulation” conditions.

Simulation 6. Utilize reverse particle tracking to evaluate flow paths and source areas for select wells.
Simulation 1 is a steady-state simulation using the average 2005-2012 pumping and return flow rates and the 30-year average recharge from 1980 to 2010 to determine if the groundwater system is in an approximate steady state. If the transient simulation were in equilibrium, then there would be little difference between the water levels; however, a comparison of water-level altitudes at the end of the transient simulation with the steady-state simulation indicates that the system has not reached equilibrium by the end of 2012 (figs. 11A-C). In the steady state simulation, most of the Qva aquifer would have declines in water levels of as much as $10 \mathrm{ft}$, with some areas having declines greater than $50 \mathrm{ft}$, that likely result from pumping. Some areas, particularly in the southwestern area of the peninsula would see rising water levels. In the QA1 aquifer, water levels decline more than $10 \mathrm{ft}$ in some areas, particularly along the southeastern edge of the peninsula. As with the Qva aquifer, some areas of the QA1 aquifer also have rising water levels. In the QA3 aquifer, there is little change from the transient simulation with water-level changes mostly declining $\pm 3 \mathrm{ft}$. The net baseflow for steady state conditions is 262,553 acre-ft/yr, which is slightly more than the 2005-2012 average of 261,637 acre-ft/yr.

In simulation 2, all pumping and return flows were removed from the model to assess the effects of the current amount of pumping on baseflows in streams and water-level altitudes. Water-level altitudes would be higher in most locations if no pumping and resulting return flows had ever occurred (figs. 12A-C). In Qva, water-level altitudes generally would be between 0 and $10 \mathrm{ft}$ higher, with limited locations exceeding $10 \mathrm{ft}$. There are also some areas where the water levels would be lower as return flows are supporting groundwater levels in those locations. Water-level altitudes in QA1 would be higher in almost all locations with a few small locations having lower water levels, particularly on the northern end of the peninsula. Water-level altitudes would all be higher in the QA3 aquifer with no pumping occurring. Those areas that currently have the most pumping have generally drawn down the water levels by 5-25 ft. Baseflow in streams would be between 1 and 3 percent higher than under current conditions (fig. 13). 


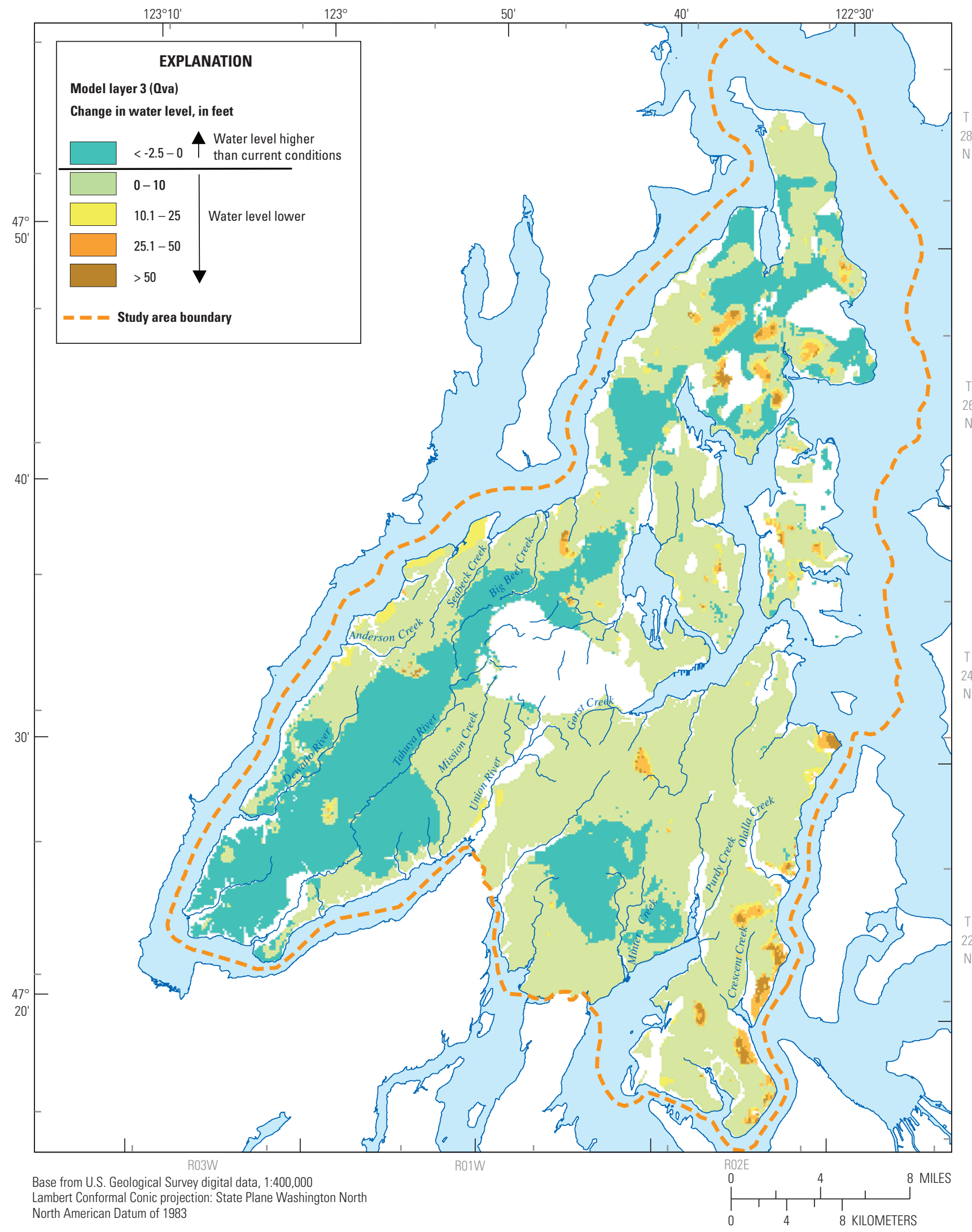

A. Model layer 3-Vashon advance aquifer (Qva).

Figure 11. Water-level altitude changes between the current conditions simulation and steady-state simulation, westcentral Washington. 


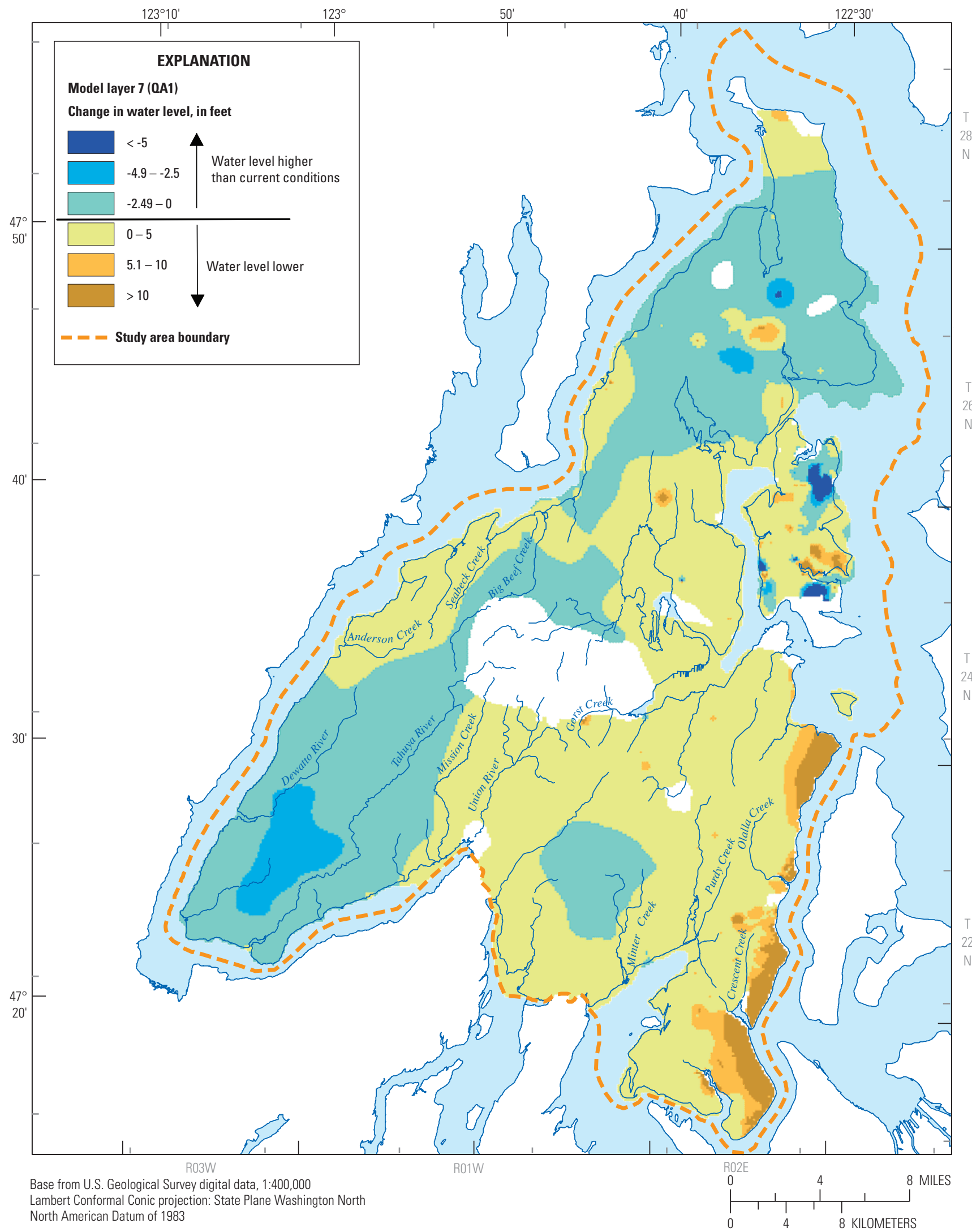

B. Model layer 7-sea-level aquifer (OA1).

Figure 11.-Continued 


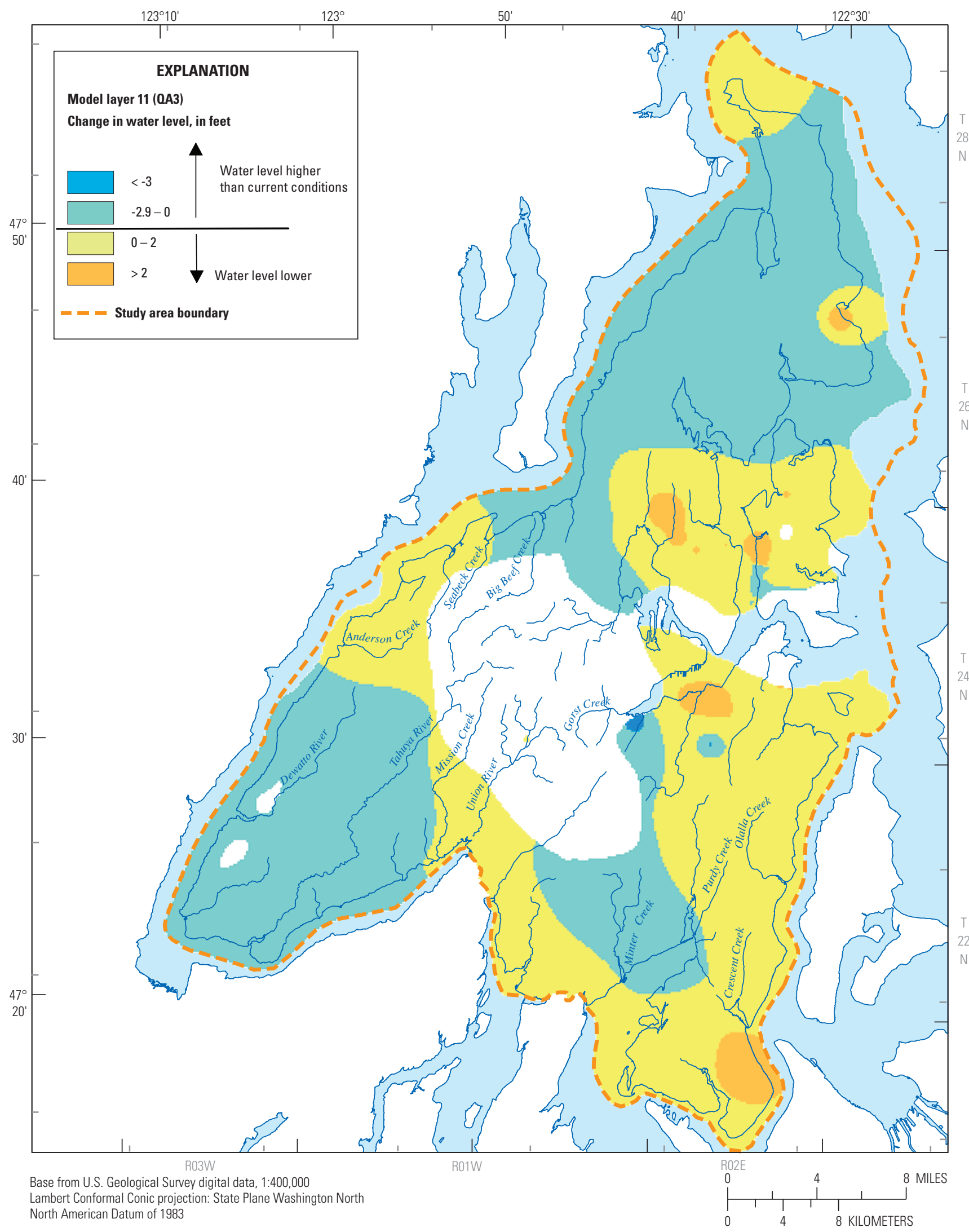

C. Model layer 11—deep aquifer (OA3).

Figure 11.-Continued 


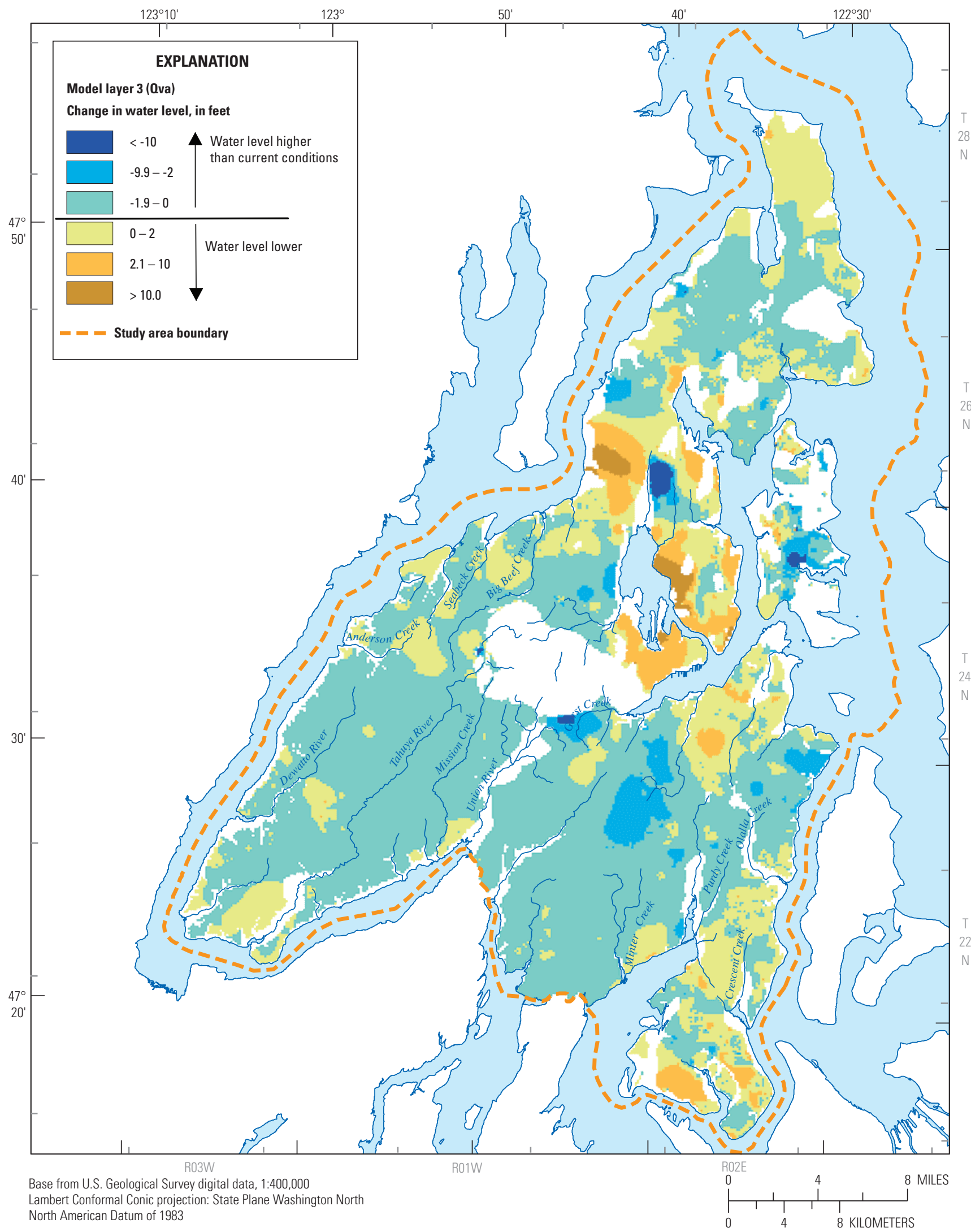

A. Model layer 3-Vashon advance aquifer (Qva).

Figure 12. Simulated water-level altitude changes between the current conditions simulation and no-pumping simulation, west-central Washington. 


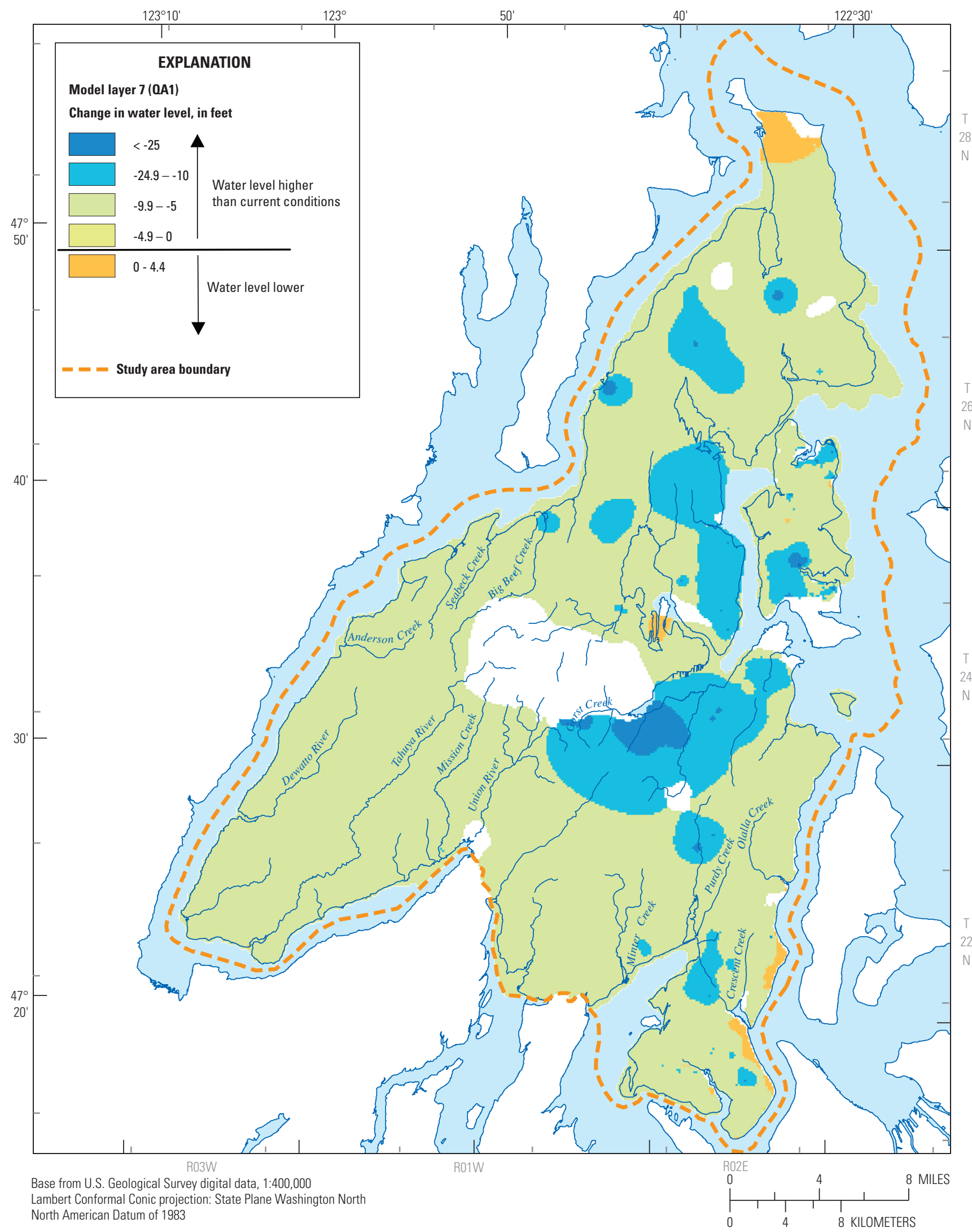

B. Model layer 7—sea-level aquifer (QA1).

Figure 12.-Continued 


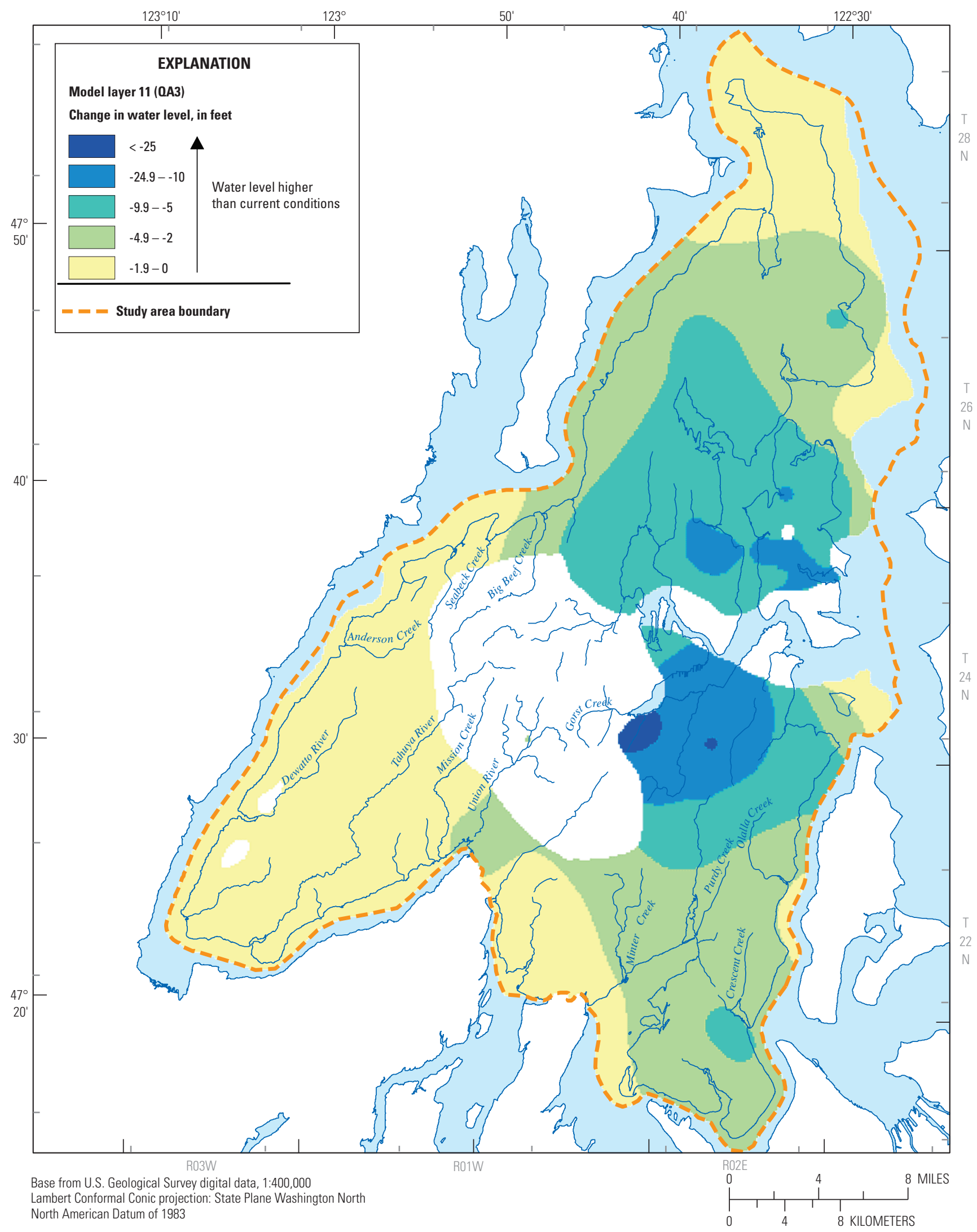

C. Model layer 11—deep aquifer aquifer (OA3).

Figure 12.-Continued 


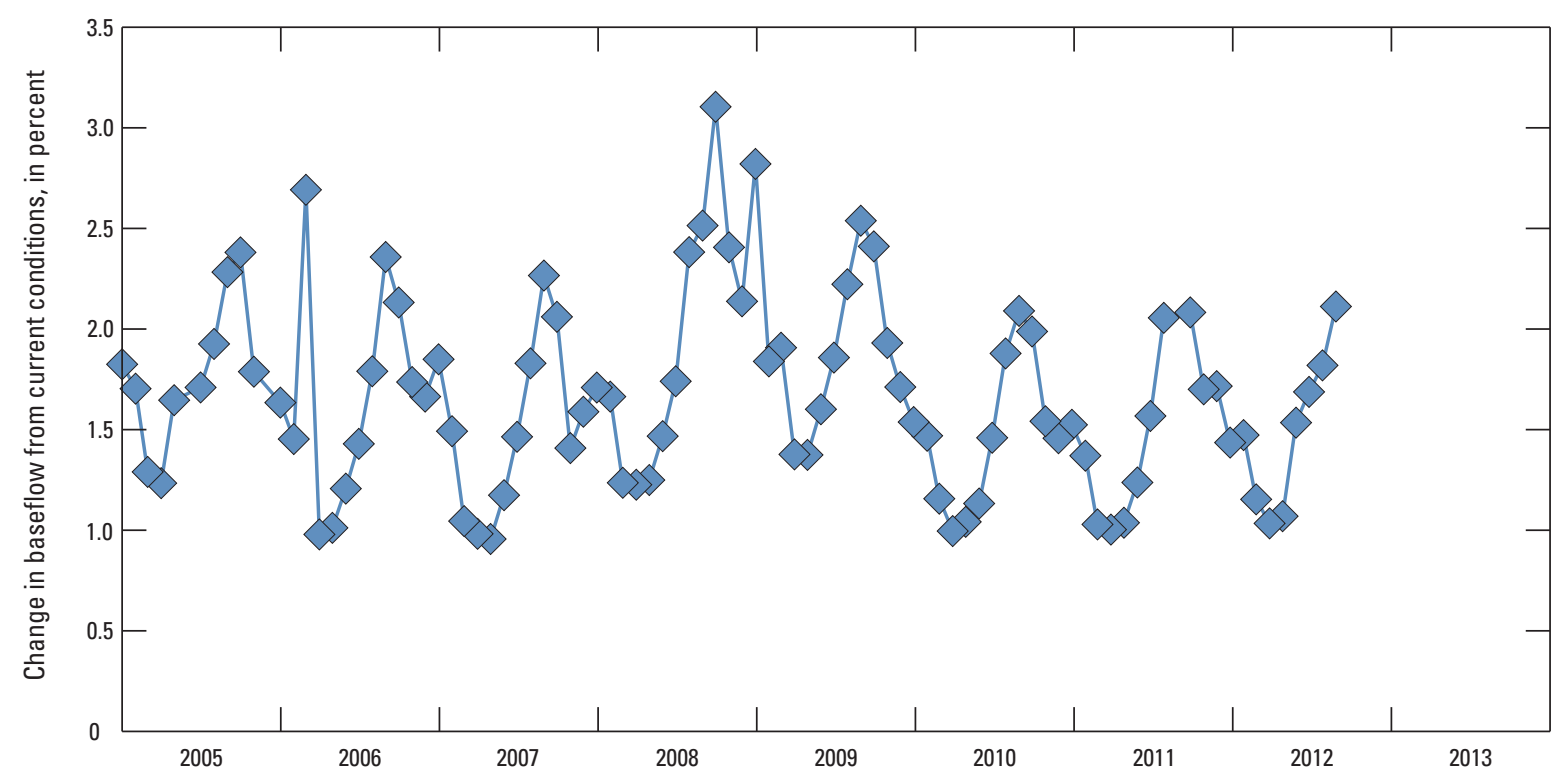

Figure 13. Change in baseflow between the current conditions simulation and the no pumping simulation, west-central Washington. Note: June 2005, December 2005, and September 2011 are not shown due to mass balance errors for those stress periods.

In simulation 3, all pumping was increased by 15 percent along with the resulting increase in return flows between 2005 and 2012. For this simulation, water-level altitudes in Qva generally would decline between 0 and $1 \mathrm{ft}$ due to the increased pumping with localized areas experiencing increased water levels generally between 0 and $2.5 \mathrm{ft}$ due to the increased return flows (fig. 14A). Water-level altitudes would all be lower in the QA1 and QA3 aquifers because of the increased pumping (figs. 14B-C). Most of the QA1 aquifer water levels would decline by $0-2 \mathrm{ft}$, as would the QA3 aquifer. Localized areas would have slightly greater declines. Baseflow in streams would be as much as 0.3 percent lower over the 2005-2012 period than under current conditions (fig. 15) as the increased pumping would capture some of the groundwater that would otherwise flow into the streams.

In simulation 4, pumping was reduced throughout the model assuming an 80 percent decrease in the amount of water that is used outdoors during 2005-2012 for May-October when outdoor residential irrigation is occurring. Return flows also were adjusted correspondingly to reflect the lower amount of water being returned as secondary recharge. In the Qva aquifer, water-level altitudes generally rise between 0 and $2 \mathrm{ft}$ with a few isolated areas rising further (fig. 16A). Declining water-level altitudes of between 0 and $3.6 \mathrm{ft}$ would occur in some areas as less water is returned to the system through secondary recharge. Water-level altitudes in the QA1 aquifer generally would rise about $1 \mathrm{ft}$, with some areas that have more pumpage rising between 1 and $6 \mathrm{ft}$ (fig. 16B). Water-level altitudes would decline in a few small areas due to less secondary recharge. All water-level altitudes in the QA3 aquifer would rise between 0 and about $4 \mathrm{ft}$ due to less pumping (fig. 16C). Baseflow in streams would be as much as 0.6 percent higher, particularly during the summer months, during 2005-2012 than under current conditions (fig. 17) as the decreased pumping would allow more of the groundwater that otherwise would be captured by the pumping wells to flow into the streams. 


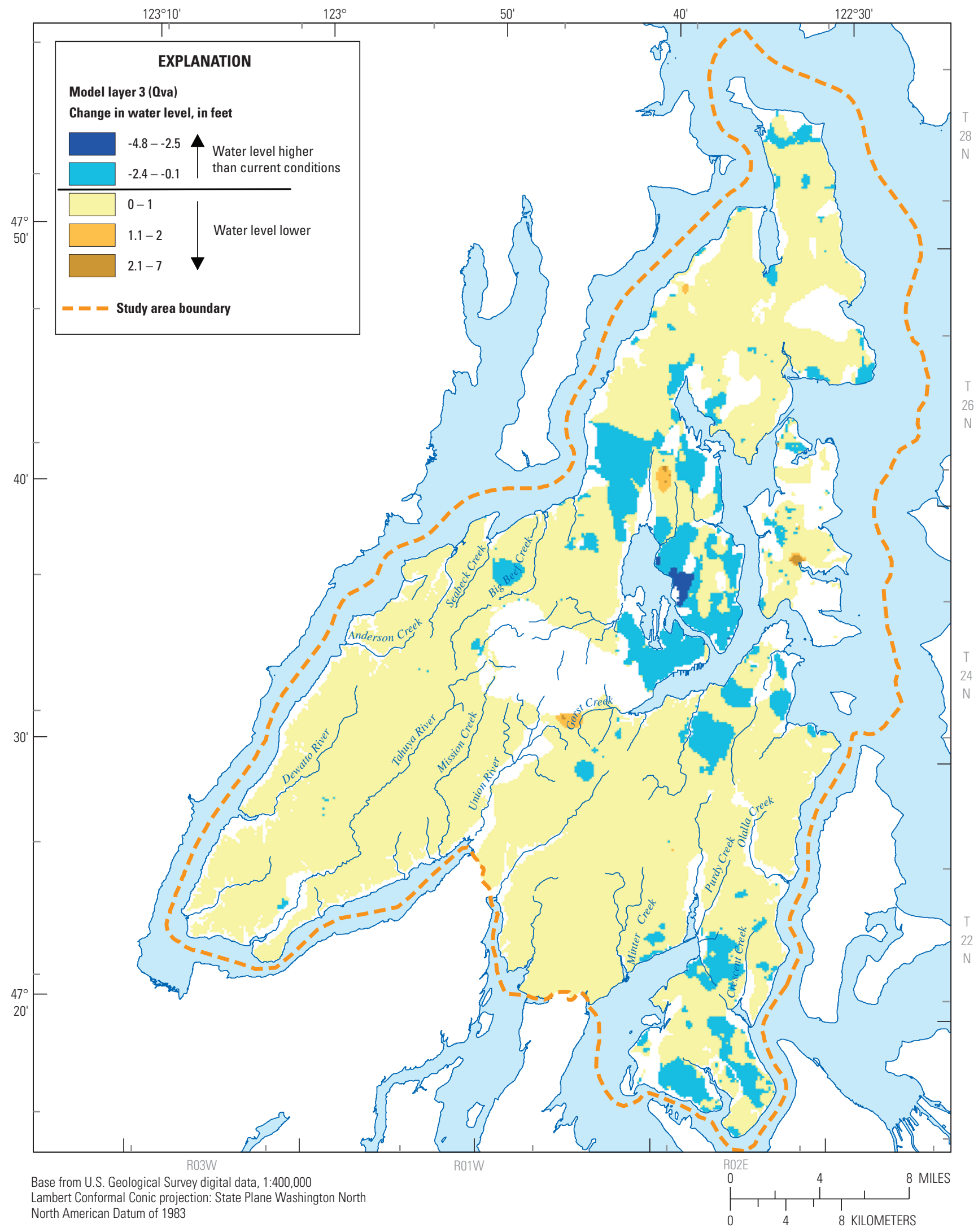

A. Model layer 3-Vashon advance aquifer (Qva).

Figure 14. Simulated water-level altitude changes between the current conditions simulation and increased pumpage simulation, west-central Washington. 


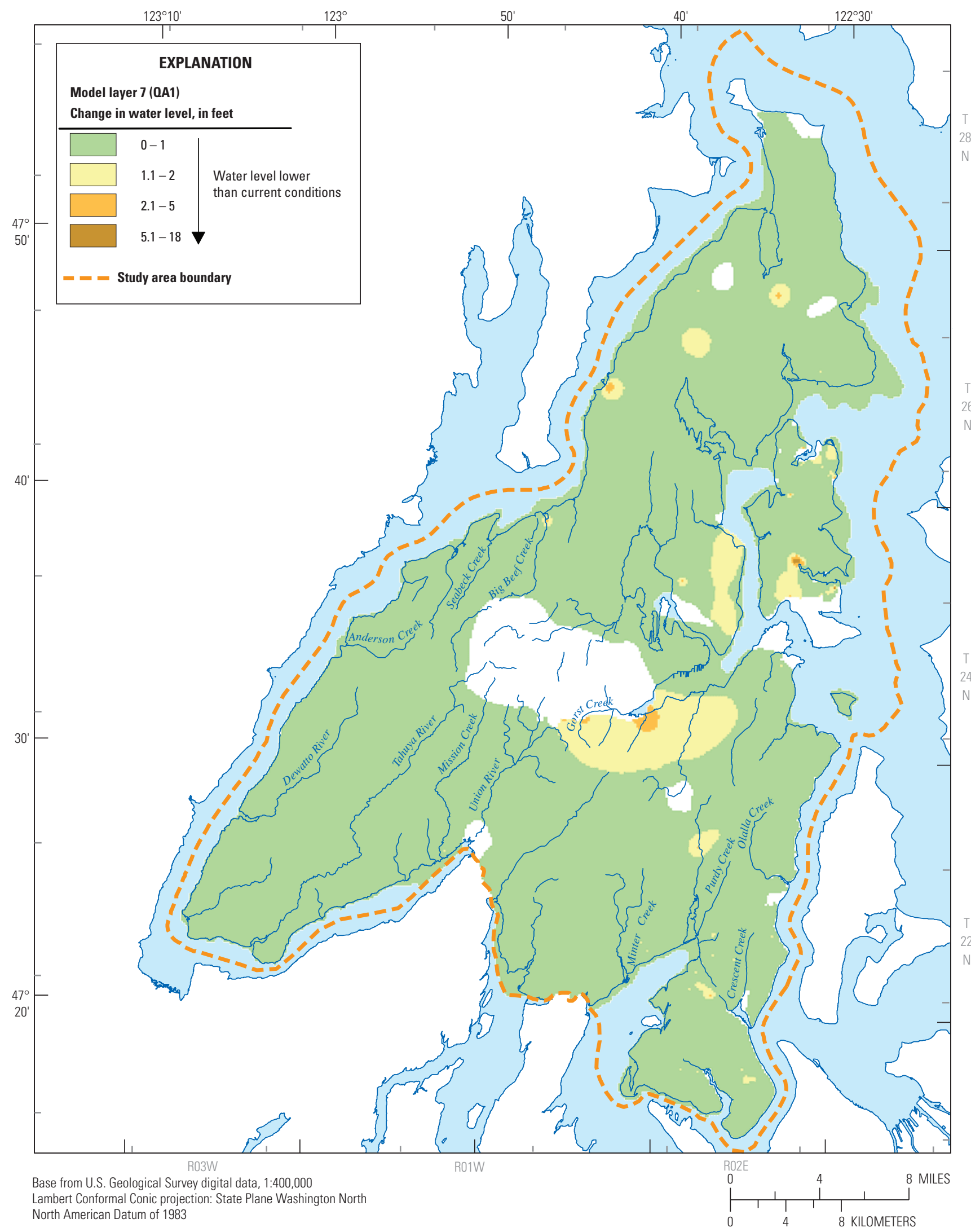

B. Model layer 7—sea-level aquifer (QA1).

Figure 14.-Continued 


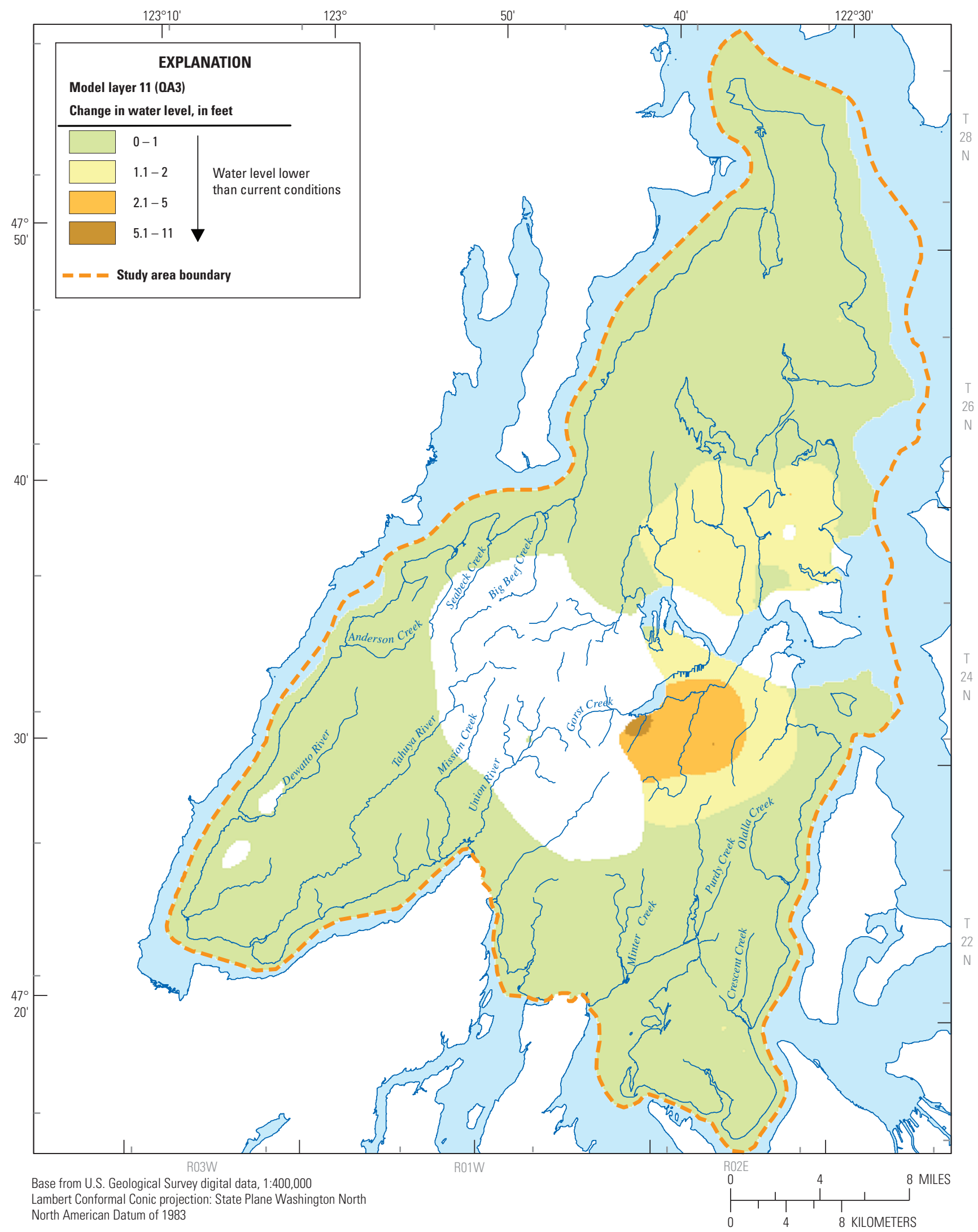

C. Model layer 11—deep aquifer (OA3).

Figure 14.-Continued 


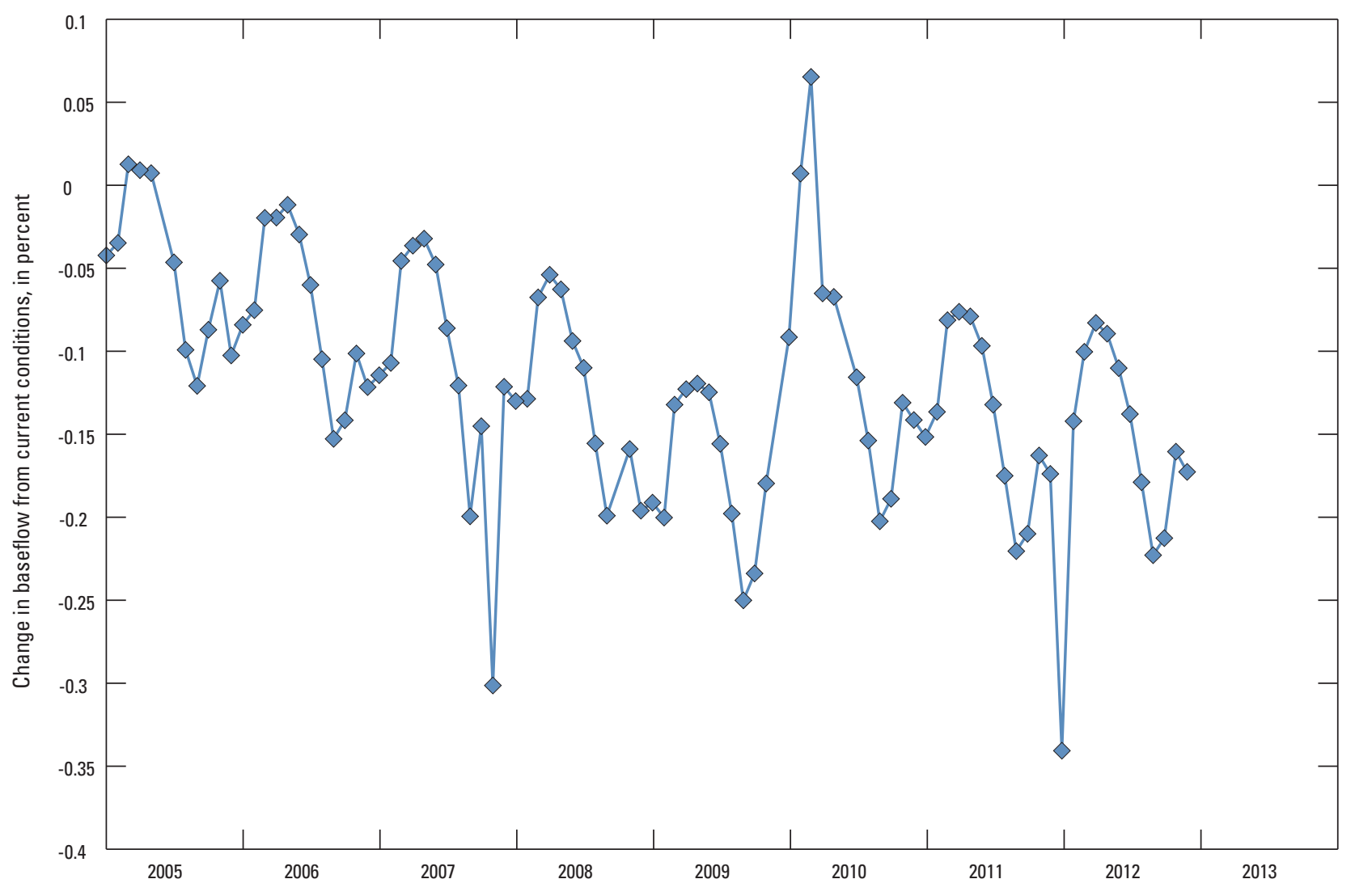

Figure 15. Change in baseflow between the current conditions simulation and the increased pumping simulation, west-central Washington. Note: June 2005, October 2008, December 2009, and June 2010 are not shown due to mass balance errors for those stress periods. 


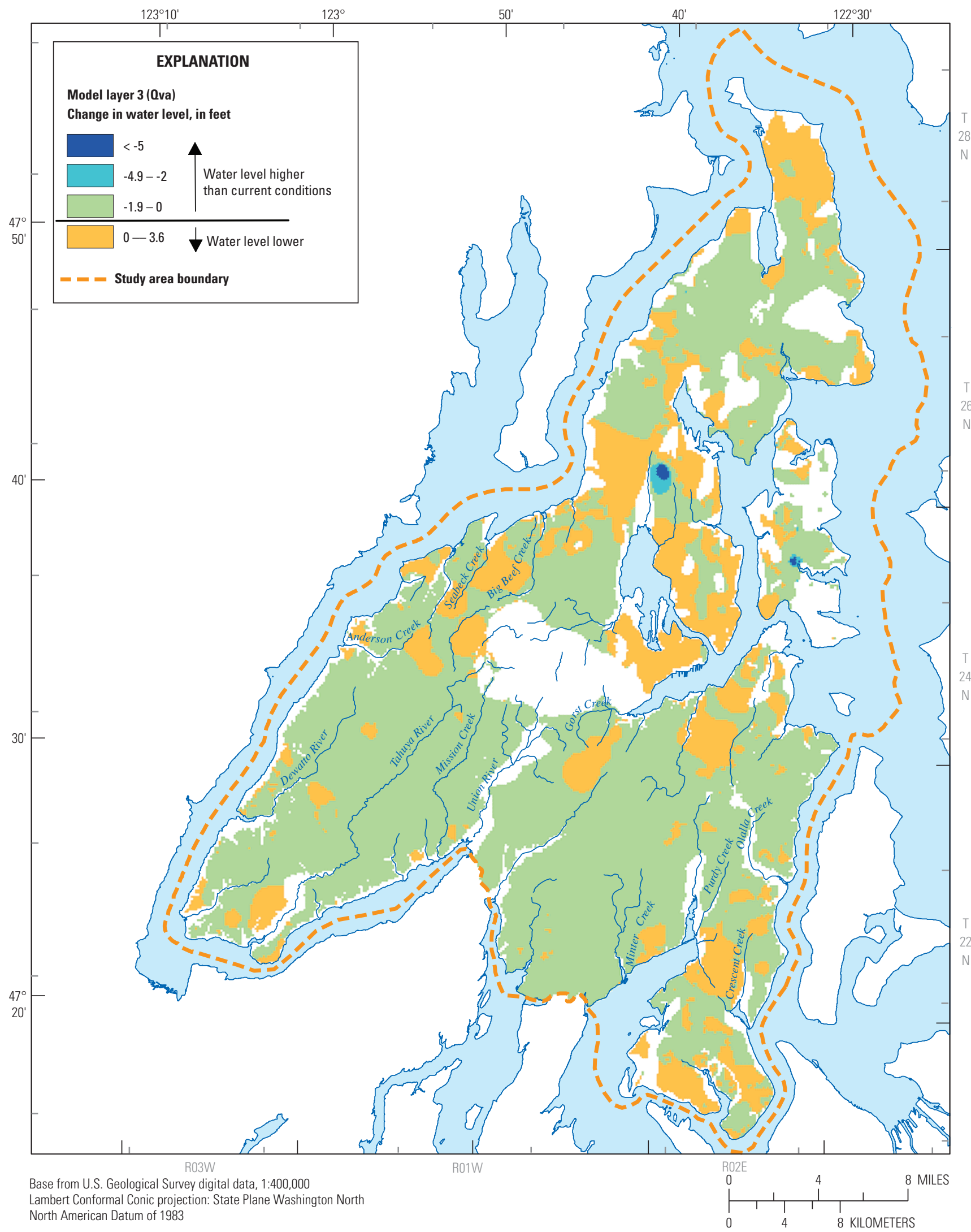

A. Model layer 3-Vashon advance aquifer (Qva).

Figure 16. Simulated water-level altitude changes between the current conditions simulation and conservation pumpage simulation for the Qva aquifer, west-central Washington. 


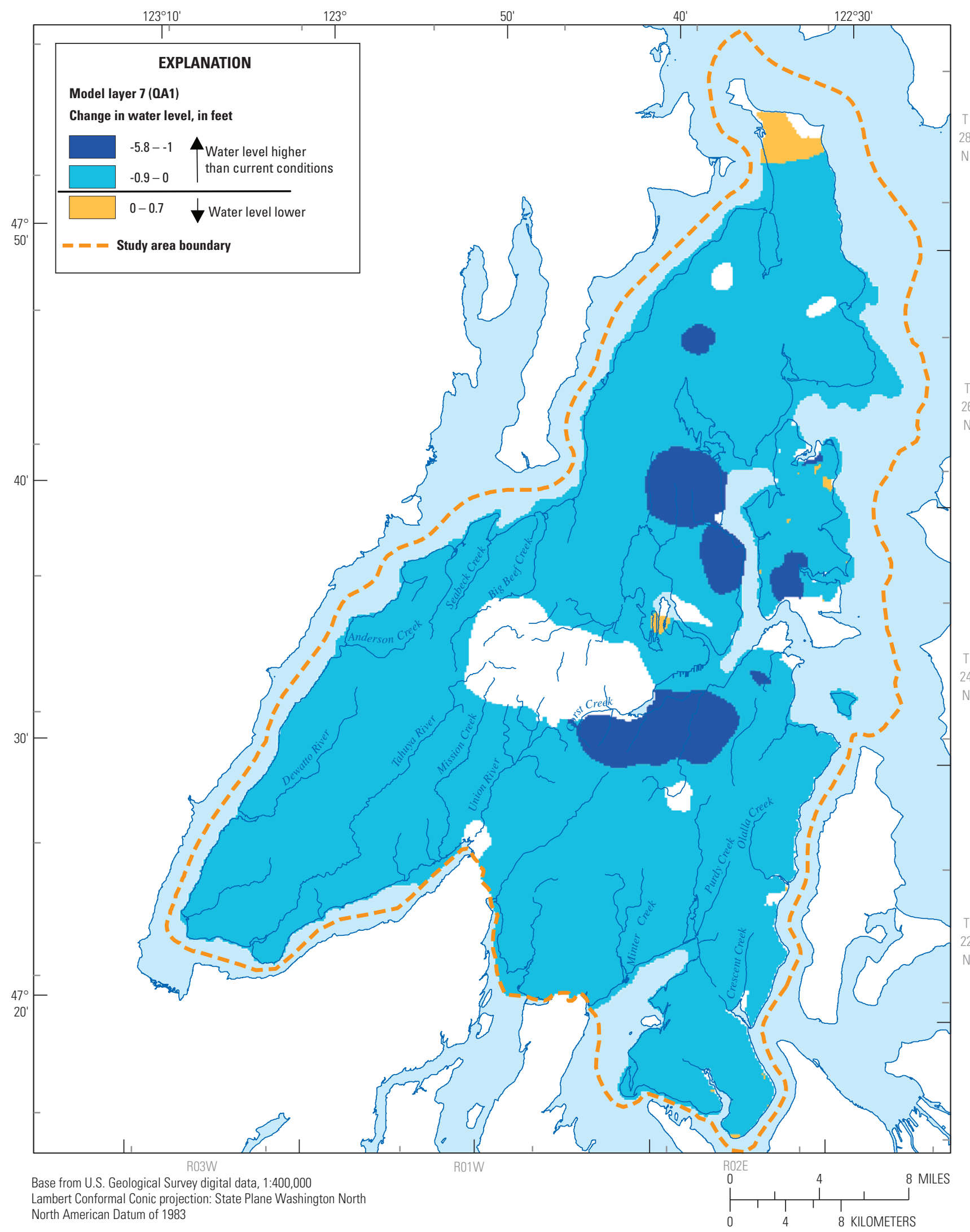

B. Model layer 7-sea-level aquifer (QA1).

Figure 16.-Continued 


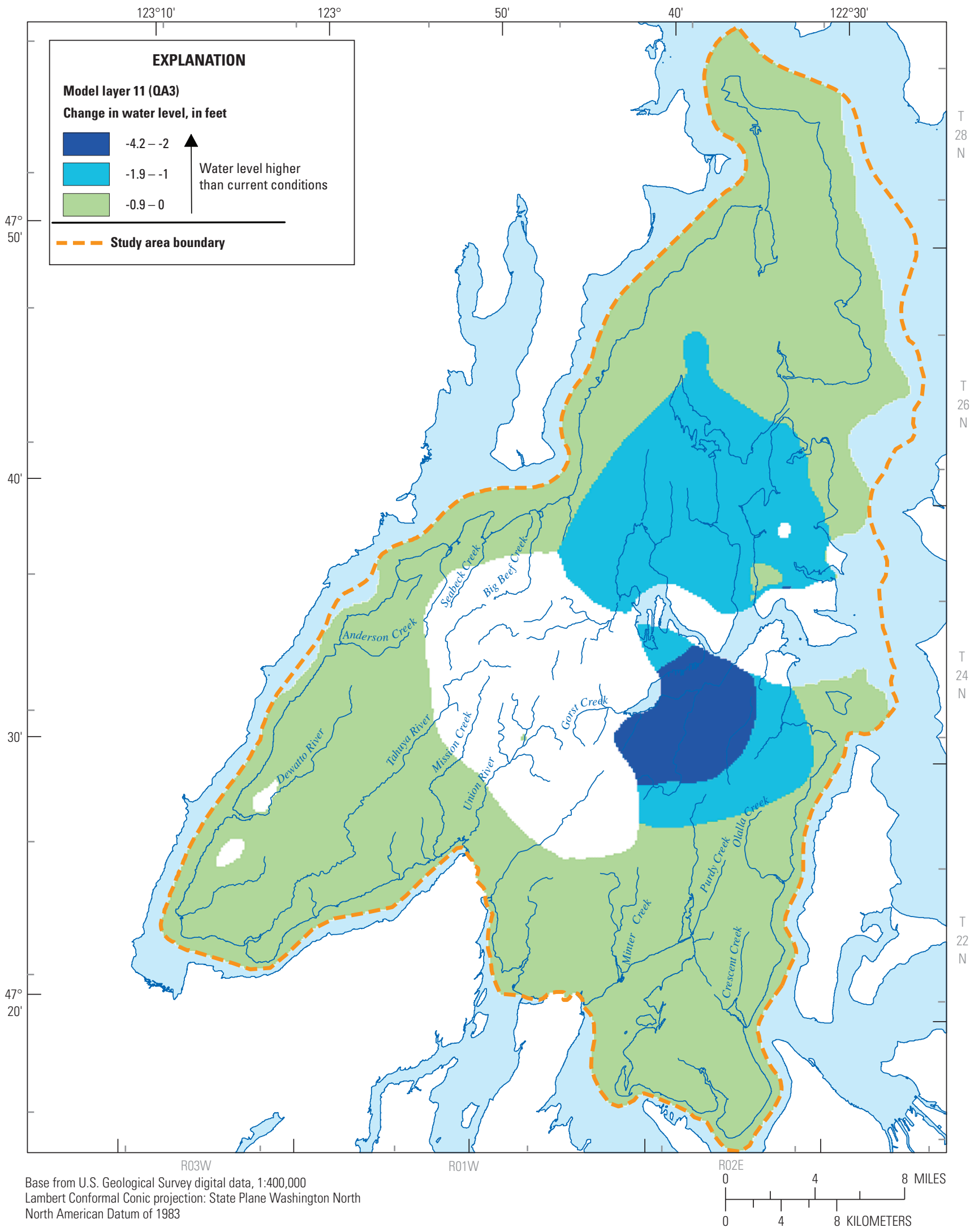

C. Model layer 11—deep aquifer (QA3).

Figure 16.-Continued 


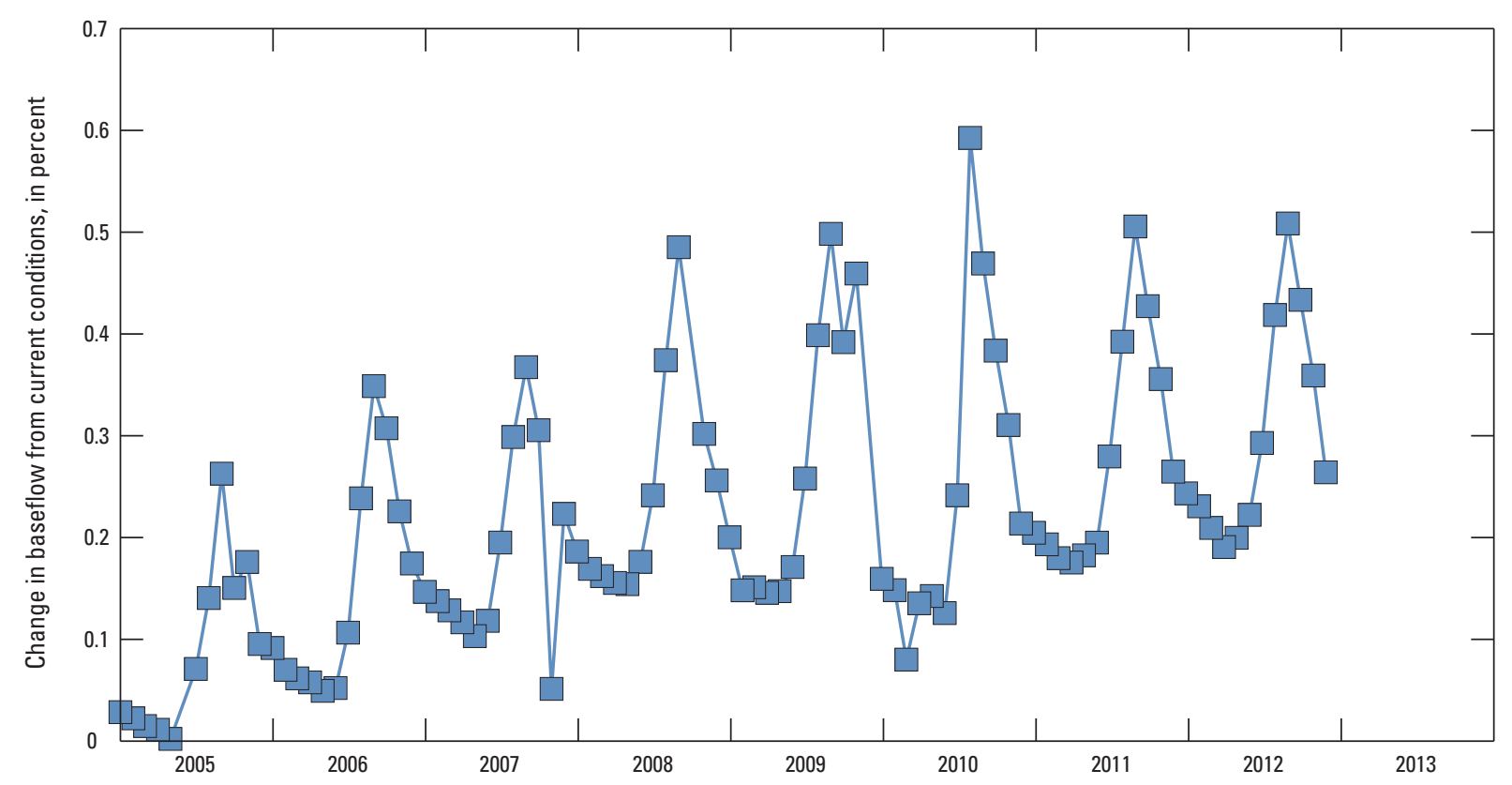

Figure 17. Change in baseflow between the current conditions simulation and the conservation simulation, west-central Washington. Note: June 2005, 0ctober 2008, and December 2009 are not shown due to mass balance errors for those stress periods.

In simulation 5, recharge was reduced by 15 percent for 2005-2012 to simulate a drought. In this simulation, all water-level altitudes declined in the Qva, QA1, and QA3 aquifers (figs. 18A-C). Water-level altitudes would decline the most in the Qva aquifer with declines generally between 0 and $25 \mathrm{ft}$. In the QA1 aquifer, most water-level altitudes generally would decline by 0 to $10 \mathrm{ft}$, with isolated areas showing greater declines. Water-level altitudes in the QA3 aquifer would decline between 0 and $5 \mathrm{ft}$. Baseflow in streams would be as much as 18 percent lower during 2005-2012 than under current conditions (fig. 19) because the decreased recharge would reduce the amount of groundwater available to flow into the streams.
In simulation 6, MODPATH was used to simulate areas that contribute recharge to water-supply wells. Protection of areas that contribute recharge for wells that provide water for water-supply systems is of interest to water purveyors. The contributing areas were delineated using the post-processing, particle-tracking computer code, MODPATH (Pollock, 1994), to backtrack simulated groundwater-flow paths from the areas of discharge to the areas of recharge. 


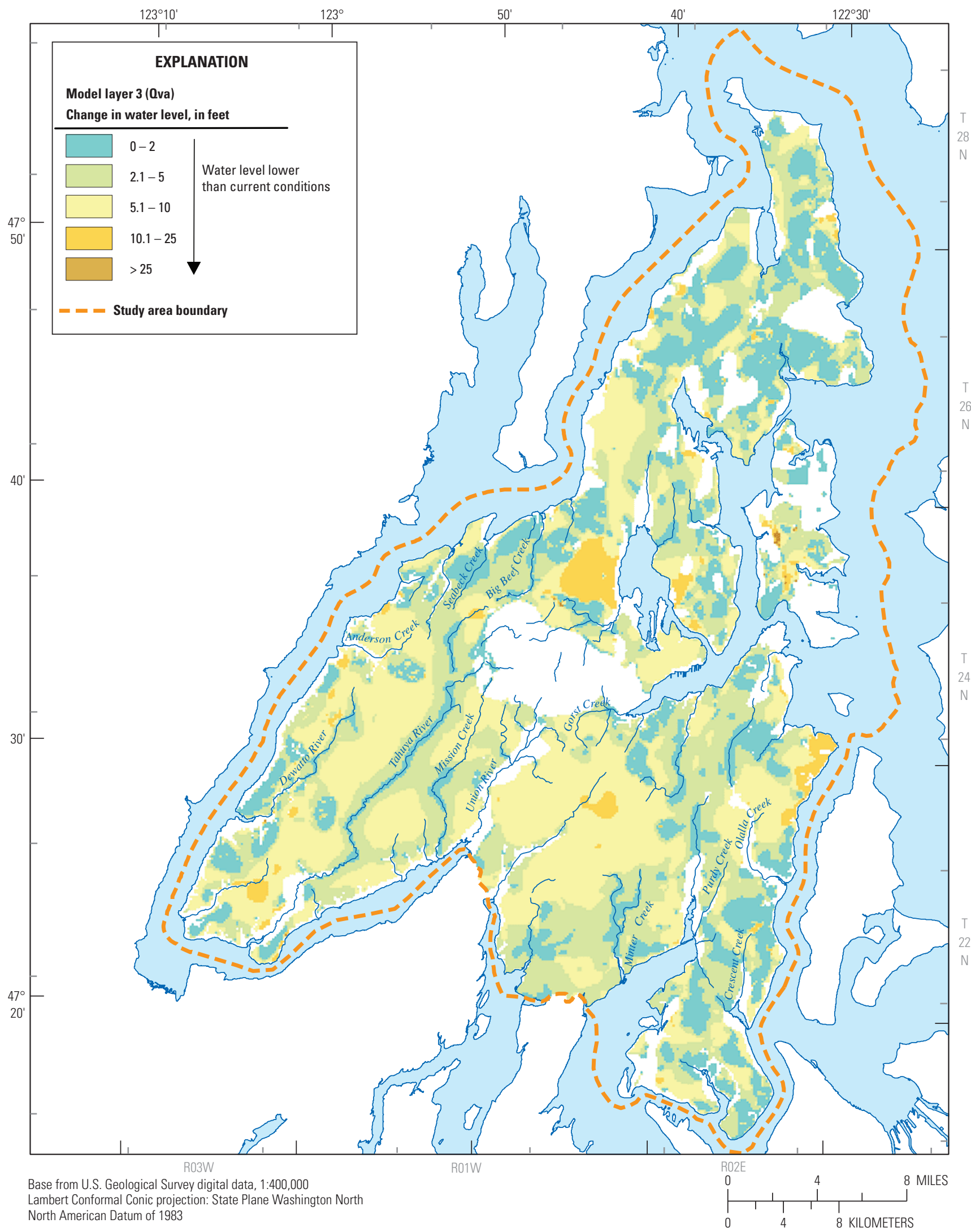

A. Model layer 3-Vashon advance aquifer (Ova).

Figure 18. Simulated water-level altitude changes between the current conditions simulation and decreased recharge simulation, west-central Washington. 


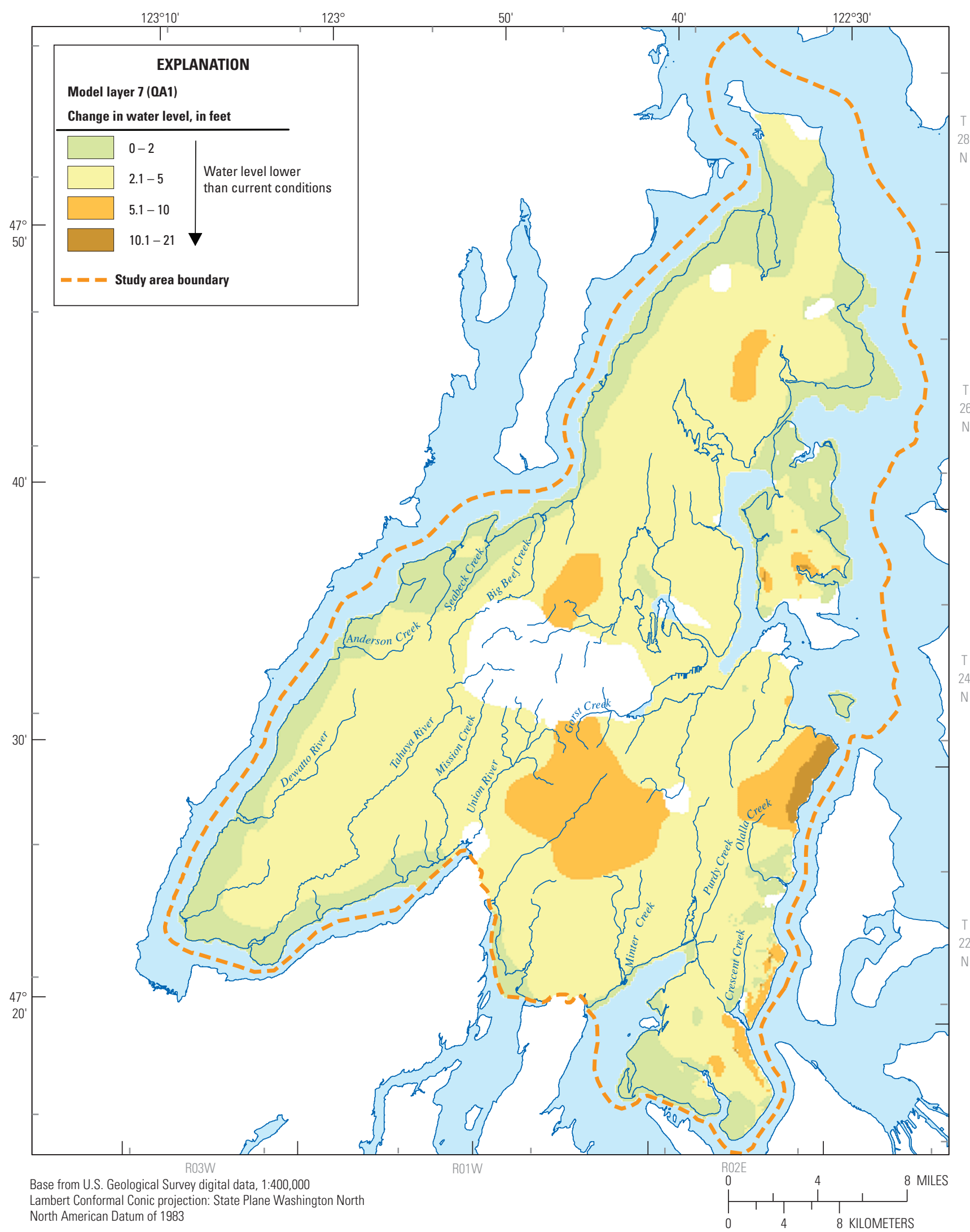

B. Model layer 7-sea-level aquifer (QA1).

Figure 18.-Continued 


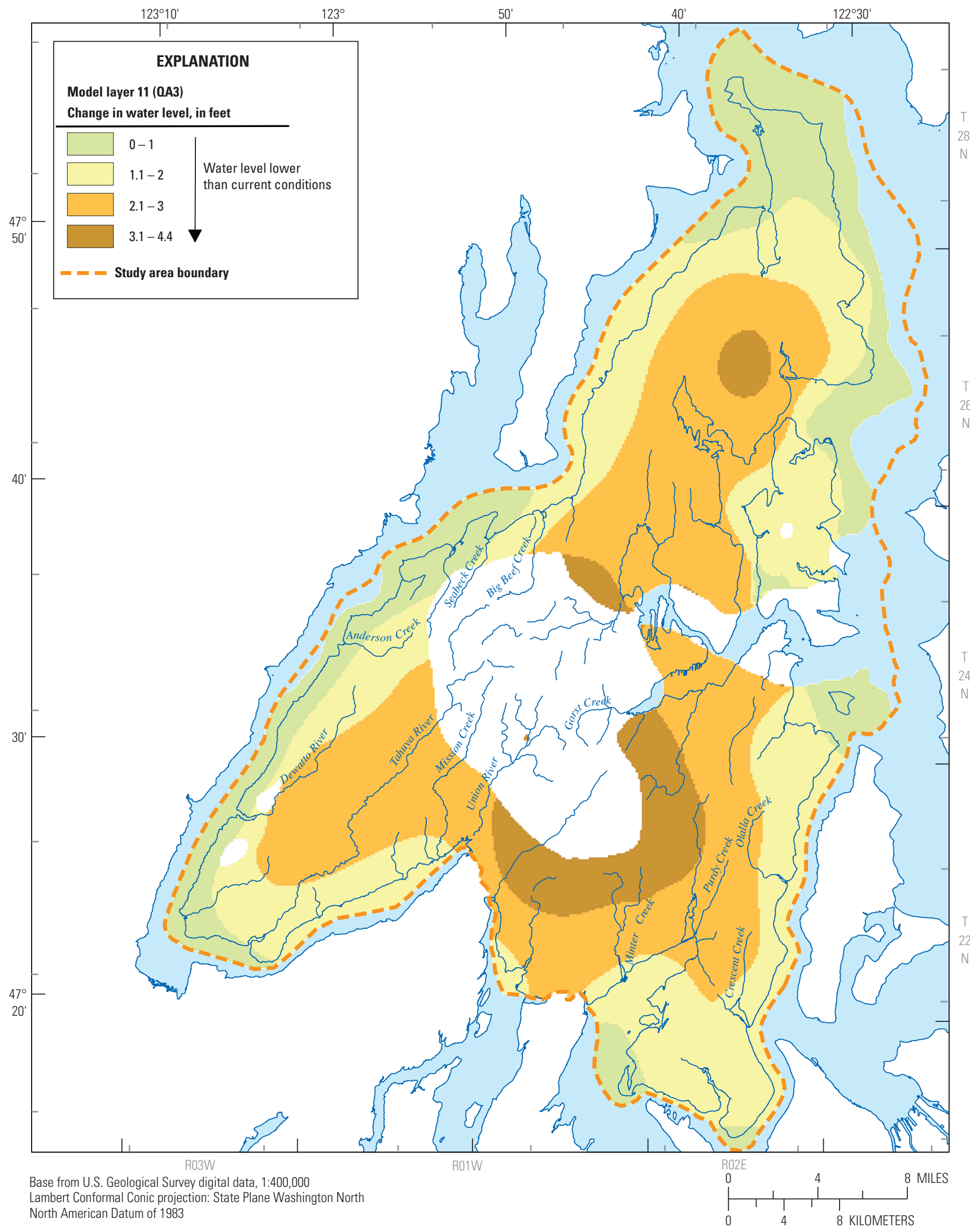

C. Model layer 11—deep aquifer (QA3).

Figure 18.-Continued 


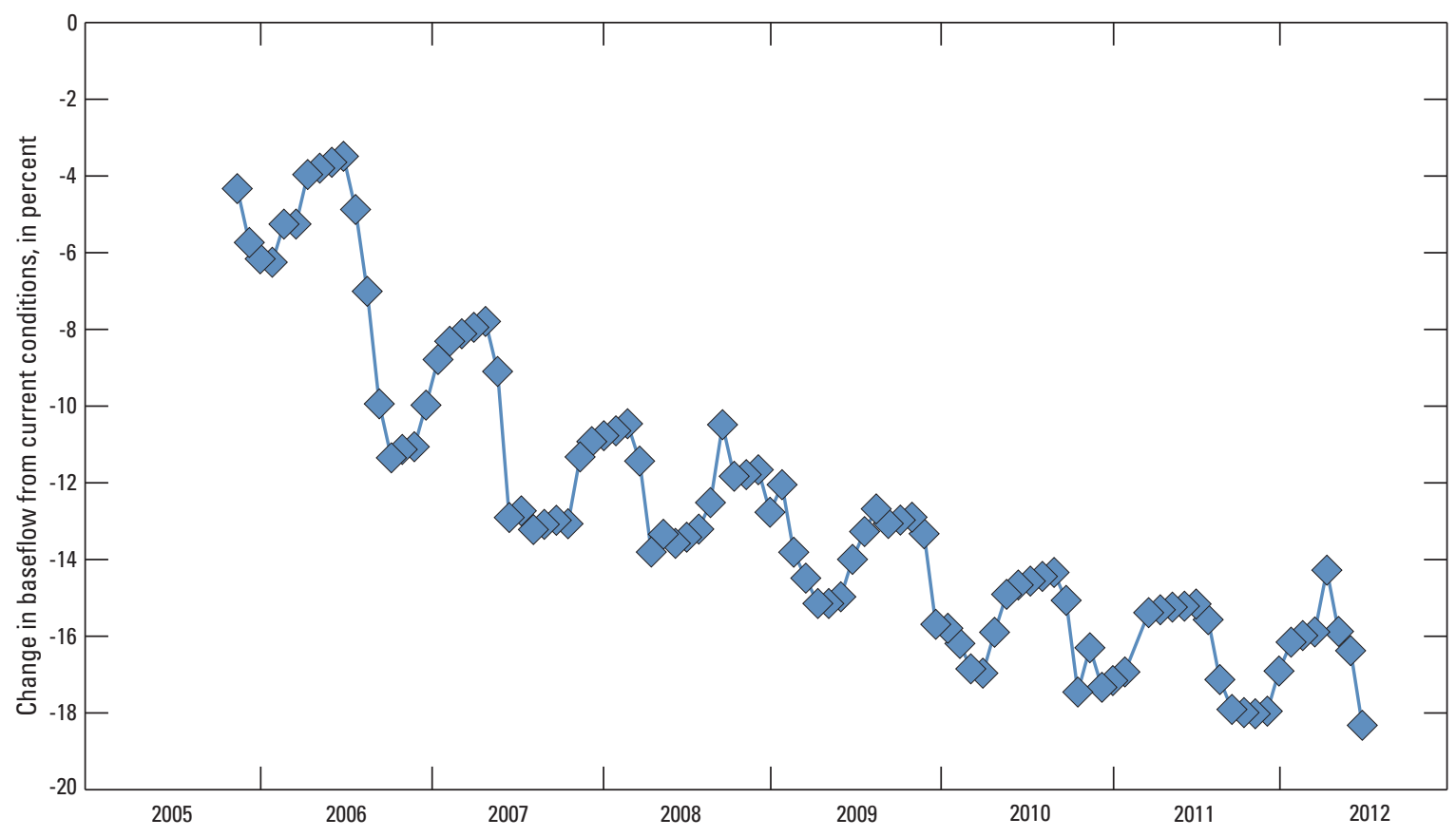

Figure 19. Change in baseflow between the current conditions simulation and the recharge decrease simulation, west-central Washington. Note: May 2011 is not shown due to mass balance errors for that stress period.

\section{MODPATH Procedure}

The computer model MODPATH uses a semi-analytical, particle-tracking scheme. The method is based on the assumption that each directional-velocity component (calculated from MODFLOW output) varies linearly within each model cell. This assumption allows an analytical expression describing the flow path within each cell to be obtained using the simulated flows through the faces of the cell. The velocity of groundwater is affected by the porosity of the material through which the groundwater is flowing. Specified porosities were 0.2 for till, 0.3 for sand and gravel aquifers, and 0.4 for clay-rich confining units (Fetter, 1994). Given the initial position of a particle, the position of the particle at any future time can be calculated. A series of calculations for successive locations of a particle provide a picture of its path through the cell and into adjacent cells if appropriate. See Pollock (1994) for a detailed discussion of the procedure. MODPATH requires initial locations of the particles to be tracked. For each cell that contained 1 of the 40 selected water-supply wells, particles were placed at the middle of each cell, at each of the 8 cell corners, at the midpoint of each of the 12 cell edges, and at the center of each of the 6 cell faces, for a total of 27 particles per cell ( 9 particles in a $3 \times 3$ array in each of 3 layers). A total of 1,080 particles were released for the simulation. The simulation was run in reverse, starting with 2012 conditions to backtrack the particles and locate areas that have contributed the bulk of the recharge to the selected wells.
Over the duration of the simulation, most particles intersected the water table and therefore were considered to have entered the model as recharge at the water table (fig. 20). Forty-eight of the particles were stranded in dry cells and did not intersect the water table. The simulated particle ending locations outline the approximate area of land surface that contributed recharge to the cells containing the water-supply wells. Travel times to the water table ranged from less than 1 day for particles placed at the water table to thousands of years for particles placed in the deepest aquifer. The median travel time for those particles that reached the water table was 236 years. Particles that started in shallower aquifers generally have shorter travel times. Particles that originated in the Qva aquifer had travel times that ranged from less than 1 day to 835 years; QC1pi particles had travel times between 16 days and 441 years; QA1 particles had travel times between 18 days and 1,500 years; QA2 particles had travel times between 1 and 2,800 years; and QA3 particles had travel times between 1 and more than 25,000 years. Simulated particle travel times are shown for one well as an example of the amount of time required for the particles to travel to the well (fig. 21). The uncertainties associated with inaccuracies in the flowsystem simulation are carried forward to these analyses, and new uncertainties are introduced. Refer to the discussion of uncertainty in the section "Model Limitations." 


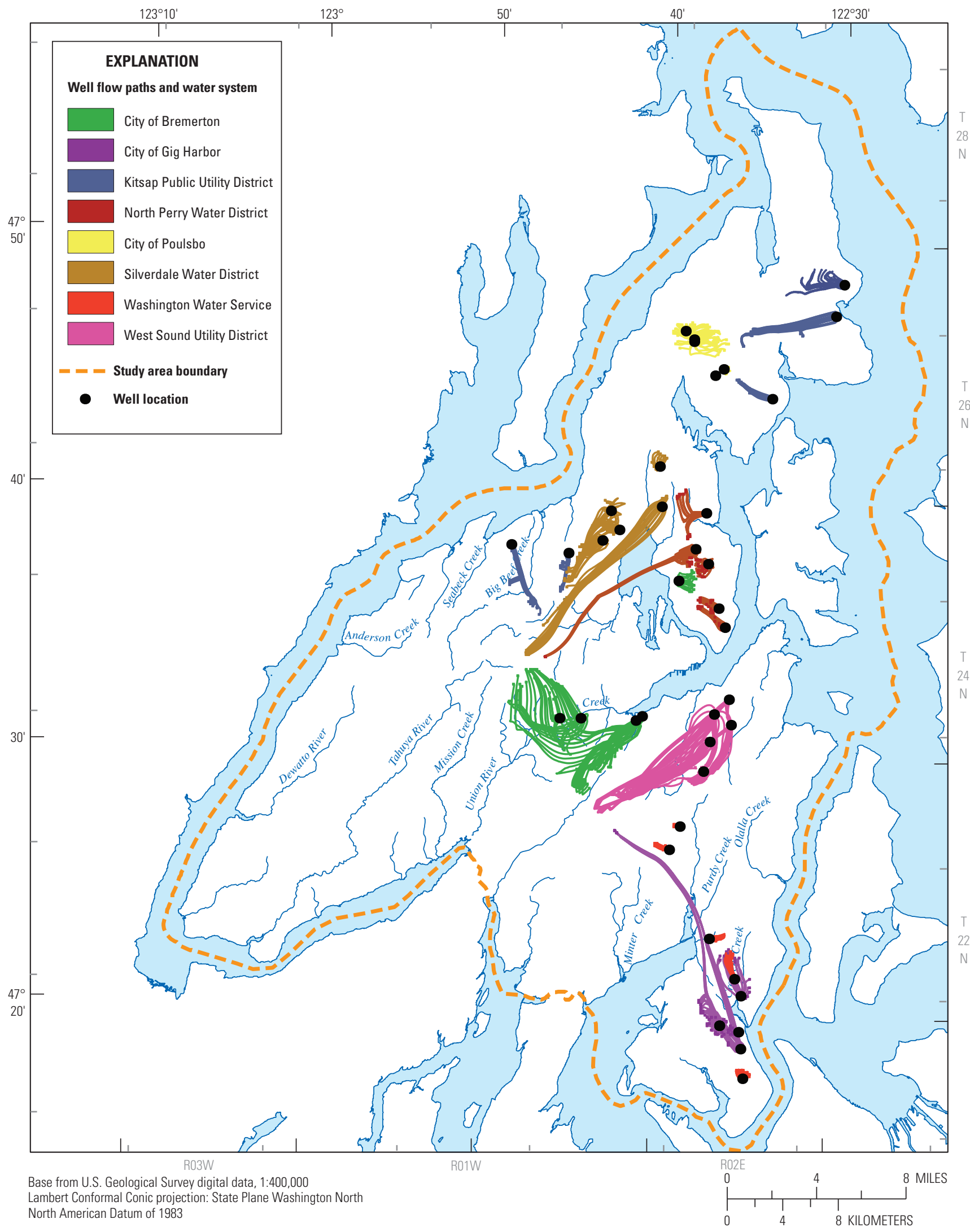

Figure 20. Particle histories for particles that terminated at the water table for selected water-supply wells in the Kitsap Peninsula, west-central Washington. 


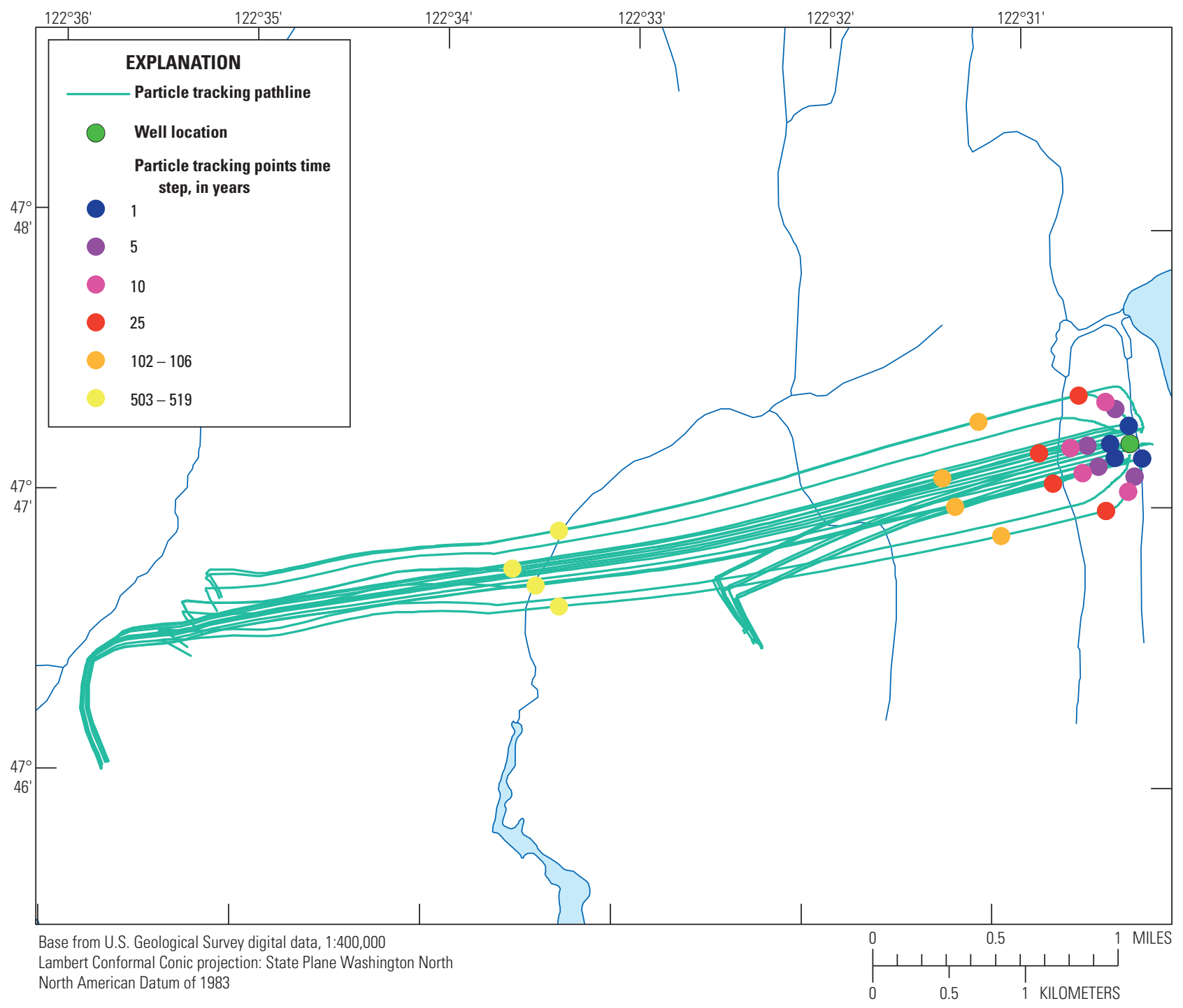

Figure 21. Time of travel for particles released from an individual water-supply well, west-central Washington. 


\section{Summary}

A groundwater-flow model was developed to improve understanding of water resources on the Kitsap Peninsula. The Kitsap Peninsula is in the Puget Sound lowland of west-central Washington, is bounded by Puget Sound on the east and by Hood Canal on the west, and covers an area of about 575 square miles. The peninsula encompasses all of Kitsap County, the part of Mason County north of Hood Canal, and part of Pierce County west of Puget Sound. The peninsula is surrounded by saltwater, and the hydrologic setting is similar to that of an island. The study area is underlain by a thick sequence of unconsolidated glacial and interglacial deposits that overlie sedimentary and volcanic bedrock units that crop out in the central part of the study area. Twelve hydrogeologic units consisting of aquifers, confining units, and an underlying bedrock unit form the basis of the groundwater-flow model.

Groundwater flow on the Kitsap Peninsula was simulated using the groundwater-flow model, MODFLOW-NWT. The finitedifference model grid comprises 536 rows, 362 columns, and 14 layers. Each model cell has a horizontal dimension of $500 \times 500$ feet, and the model contains 1,227,772 active cells. The thickness of model layers varies throughout the model area. Boundary conditions representing inflow and outflow components were implemented using packages in MODFLOW-NWT. The Recharge Package was used to represent recharge from precipitation. The Well Package was used to represent withdrawals from wells and return flows from septic systems. The Streamflow-Routing Package was used to represent the exchange of water between streams and the aquifer system. The Drain Package was used to represent groundwater discharge to springs and seeps, and the General-Head Boundary Package was used to represent lakes and Puget Sound.

Groundwater flow was simulated in unconsolidated glacial (till and outwash) and interglacial (fluvial and lacustrine) deposits in the Kitsap Peninsula. A previous study established a hydrologic framework that was used for this study to delineate 12 hydrogeologic units comprising aquifers and confining units within the model domain that are represented using 14 model layers. Initial estimates and probable ranges of values for hydraulic properties used during model calibration were defined from data collected during previous studies in and adjacent to the model area.

Groundwater flow was simulated for transient conditions. Transient conditions were simulated for January 1985-December 2012 using annual stress periods for 1985-2004 and monthly stress periods for 2005-2012. During model calibration, variables were adjusted within probable ranges to minimize differences between measured and simulated water levels and stream baseflows. The model as calibrated to transient conditions has a standard deviation for heads and flows of 47.01 feet and 212,445.73 cubic feet per day, respectively.
Simulated inflow to the model area for 2005-2012 from precipitation and secondary recharge were 563,130 and 22,193 acre-feet per year (acre-ft/yr), respectively (93 percent of total simulated inflow ignoring changes in storage), and simulated inflow from stream and lake leakage was 43,905 acre-ft/yr (7 percent of total simulated inflow). Simulated outflow from the model primarily was through discharge to streams, lakes, springs, seeps, and Puget Sound (594,595 acre-ft/yr; 95 percent of total simulated outflow excluding changes in storage), and withdrawals from wells (30,761 acre-ft/yr; 5 percent of total simulated outflow excluding changes in storage).

Six scenarios were formulated with input from project stakeholders and simulated using the calibrated model to provide representative examples of how the model can be used to evaluate the effects on water levels and stream baseflows of potential changes in groundwater withdrawals, in consumptive use, and in recharge. These included simulations of a steady-state system, no-pumping and return flows, increased current withdrawals in all wells by 15 percent, decreased current outdoor water use by 80 percent to simulate effects of conservation efforts, decreased recharge from precipitation by 15 percent to simulate a drought, and particle tracking to determine flow paths.

Changes in water-level altitudes and baseflow amounts vary depending on the stress applied to the system in the various scenarios. Decreasing recharge by 15 percent between 2005 and 2012 had the largest effect with water-level altitudes declining throughout the model domain and baseflow amounts decreasing by as much as 18 percent compared to baseline conditions. Changes in pumping volumes had a smaller effect on the model simulations. Removing all pumping and resulting return flows resulted in rising water-level altitudes in many, but not all, areas and increased baseflow amounts of between 1 and 3 percent.

\section{References Cited}

Anderson, M.R., and Woessner, W.W., 1992, Applied groundwater modeling simulation of flow and advective transport: San Diego/New York/Boston/London/Sydney/ Tokyo/Toronto, Academic Press, Inc., 381 p.

Bidlake, W.R., and Payne, K.L., 2001, Estimating recharge to groundwater from precipitation at Naval Submarine Base Bangor and vicinity, Kitsap County, Washington: U.S. Geological Survey Water-Resources Investigations Report 01-4110, 33 p. [Also available at https://pubs.er.usgs.gov/ publication/wri014110.] 
Bredehoeft, J.D., Papadopulos, S.S., and Cooper, H.H., Jr., 1982, Groundwater-The water-budget myth, in Geophysics Study Committee, eds., Scientific basis of water-resource management: National Academy Press, p. 51-57.

de Marsily, Ghislain, Lavedan, G., Boucher, M., and Fasanino, G., 1984, Interpretation of interference tests in a well field using geostatistical techniques to fit the permeability distribution in a reservoir model, in Verly, George, David, Michel, Journel, A.G., and Marechal, Alain, eds., Geostatistics for natural resources characterization, Part 2: Dordrecht, Netherlands, D. Reidel Publishing Company, p. 831-849.

Doherty, J., 2005, PEST-Model-independent parameter estimation: Corinda, Australia, Watermark Numerical Computing, [variously paged].

Doherty, J., 2006, Addendum to PEST manual: Corinda, Australia, Watermark Numerical Computing, [variously paged].

Doherty, J., Fienen, M.N., and Hunt, R.J., 2010, Approaches to highly parameterized inversion-Pilot-point theory guidelines, and research directions: U.S. Geological Survey Scientific Investigations Report 2010-5168, 36 p. [Also available at http://pubs.usgs.gov/sir/2010/5168/.]

Doherty, J.E., and Hunt, R.J., 2010, Approaches to highly parameterized inversion-A guide to using PEST for groundwater-model calibration: U.S. Geological Survey Scientific Investigations Report 2010-5169, 59 p. [Also available at http://pubs.usgs.gov/sir/2010/5169/.]

Doherty, John, 2003, Ground water model calibration using pilot points and regularization: Ground Water, v. 41, no. 2, p. $170-177$.

Drost, B.W., Ely, D.M., and Lum, W.E., 1999, Conceptual model and numerical simulation of the ground-water flow system in the unconsolidated sediments of Thurston County, Washington: U.S. Geological Survey Water-Resources Investigations Report 99-4165, 106 p. [Also available at http://pubs.usgs.gov/wri/wri994165/.]

Fetter, C.W., 1994, Applied hydrogeology, 3rd ed.: Prentice Hall, 691 p.

Fienen, M.N., Muffels, C.J., and Hunt, R.J., 2009, Methods note-On constraining pilot point calibration with regularization in PEST: Ground Water, v. 47, no. 6, p. 835-844.
Frans, L.M., Bachmann, M.P., Sumioka, S.S., and Olsen, T.D., 2011, Conceptual model and numerical simulation of the groundwater-flow system of Bainbridge Island, Washington: U.S. Geological Survey Scientific Investigations Report 2011-5021, 96 p. [Also available at http://pubs.usgs.gov/ sir/2011/5021/.]

Freeze, R.A., and Cherry, J.A., 1979, Ground water: Englewood Cliffs, New Jersey, Prentice-Hall, 604 p.

Johnson, K.H., Savoca, M.E., and Clothier, Burt, 2011, Numerical simulation of the groundwater-flow system in the Chambers-Clover Creek Watershed and vicinity, Pierce County, Washington: U.S. Geological Survey Scientific Investigations Report 2011-5086, 108 p. [Also available at http://pubs.usgs.gov/sir/2011/5086/.]

Jones, M.A., 1996, Thickness of unconsolidated deposits in the Puget Sound lowland, Washington and British Columbia: U.S. Geological Survey Water-Resources Investigations Report 94-4133, 1 plate, scale 1:500,000. [Also available at https://pubs.er.usgs.gov/publication/ wri944133.]

Jones, M.A., 1999, Geologic framework for the Puget Sound aquifer system, Washington and British Columbia: U.S. Geological Survey Professional Paper 1424-C, 31 p, 18 plates. [Also available at https://pubs.er.usgs.gov/ publication/pp1424C.]

Lane, R.C., 2009, Estimated water use in Washington, 2005: U.S. Geological Survey Scientific Investigations Report 2009-5128, 30 p. [Also available at http://pubs.usgs.gov/ sir/2009/5128/.]

LaVenue, A.M., and Pickens, J.F., 1992, Application of a coupled adjoint sensitivity and kriging approach to calibrate a groundwater flow model: Water Resources Research, v. 28 , no. 6 , p. $1,543-1,569$.

Magirl, C.S., and Olsen, T.D., 2009, Navigability potential of Washington rivers and streams determined with hydraulic geometry and a geographic information system: U.S. Geological Survey Scientific Investigations Report 2009-5122, 22 p. [Also available at http://pubs.usgs.gov/ sir/2009/5122/.]

McDonald, M.G., and Harbaugh, A.W., 1988, A modular three-dimensional finite-difference ground-water flow model: U.S. Geological Survey Techniques of Water Resources Investigations, book 6, chap. Al, 586 p. [Also available at http://pubs.usgs.gov/twri/twri6a1/.] 
Niswonger, R.G., Panday, S., and Ibaraki, M., 2011, MODFLOW-NWT, A Newton formulation for MODFLOW-2005: U.S. Geological Survey Techniques and Methods, book 6, chap. A37, 44 p. [Also available at http:// pubs.usgs.gov/tm/tm6a37/.]

Niswonger, R.G., and Prudic, D.E., 2005, Documentation of the Streamflow-Routing (SFR2) Package to include unsaturated flow beneath streams-A modification to SFR1: U.S. Geological Survey Techniques and Methods, book 6, chap. A13, 50 p. [Also available at http://pubs.usgs.gov/ tm/2006/tm6A13/.]

Petkewich, M.D., and Campbell, B.G., 2007, Hydrogeology and simulation of ground-water flow near Mount Pleasant, South Carolina-Predevelopment, 2004, and predicted scenarios for 2030: U.S. Geological Survey Scientific Investigations Report 2007-5126, 79 p. [Also available at http://pubs.usgs.gov/sir/2007/5126/.]

Pollock, D.W., 1994, User's Guide for MODPATH/ MODPATH-PLOT, version 3-A particle tracking postprocessing package for MODFLOW, the U.S. Geological Survey finite-difference ground-water flow model: U.S. Geological Survey Open-File Report 94-464, variously paginated.

Riley, F.S., 1998, Mechanics of aquifer systems - The scientific legacy of Joseph F. Poland, in Borchers, J.W., ed., Land subsidence case studies and current research : Proceedings of the Dr. Joseph F. Poland Symposium on Land Subsidence, Sacramento, Calif., October 4-5, 1995, Association of Engineering Geologists Special Publication, no. 8, p. 13-27.

Sceva, J.E., 1957, Geology and ground-water resources of Kitsap County, Washington: U.S. Geological Survey WaterSupply Paper 1413, 178 p. [Also available at https://pubs. er.usgs.gov/publication/wsp1413.]
Theis, C.V., 1940, The source of water derived from wells: Civil Engineering, v. 10, no. 5, p. 277-280.

Troutman, B.M., 1985, Errors and parameter estimation in precipitation-runoff modeling 2-Case study: Water Resources Research, v. 21, no. 8, p. 1,214-1,222.

U.S. Geological Survey, 2014, Hydrography-National hydrography dataset, watershed boundary dataset: U.S. Geological Survey Web site, accessed August 27, 2013, at http://nhd.usgs.gov/index.html.

Vaccaro, J.J., Hansen, A.J., and Jones, M.A., 1998, Hydrogeologic framework of the Puget Sound aquifer system, Washington and British Columbia: U.S. Geological Survey Professional Paper 1424-D, 77 p. [Also available at https://pubs.er.usgs.gov/publication/pp1424D.]

van Heeswijk, Marijke, and Smith, D.T., 2002, Simulation of the ground-water flow system at Naval Submarine Base Bangor and vicinity, Kitsap County, Washington: U.S. Geological Survey Water-Resources Investigations Report 02-4261, 142 p.

Washington State Department of Ecology, 2009, Final cost benefit, maximum net benefit, and least burdensome analyses, chapter 173-517: Washington Administrative Code Water Resources Program for the Quilcene-Snow Watershed, Water Resources Inventory Area (WRIA) 17, Publication No. 09-11-029.

Welch, W.B., Frans, L.M., and Olsen, T.D., 2014, Hydrogeologic framework, groundwater movement, and water budget of the Kitsap Peninsula, westcentral Washington: U.S. Geological Survey Scientific Investigations Report 2014-5106, 44 p., accessed May 6, 2015, at http://dx.doi.org/10.3133/sir20145106. 

Publishing support provided by the U.S. Geological Survey

Science Publishing Network, Tacoma Publishing Service Center

For more information concerning the research in this report, contact the Director, Washington Water Science Center

U.S. Geological Survey

934 Broadway, Suite 300

Tacoma, Washington 98402

http://wa.water.usgs.gov 
